\title{
A user's guide to basic knot and link theory *
}

\author{
A. Skopenkov ${ }^{\dagger}$
}

\begin{abstract}
This is an expository paper. We define simple invariants of knots or links (linking number, Arf-Casson invariants and Alexander-Conway polynomials) motivated by interesting results whose statements are accessible to a non-specialist or a student. The simplest invariants naturally appear in an attempt to unknot a knot or unlink a link. Then we present certain 'skein' recursive relations for the simplest invariants, which allow to introduce stronger invariants. We state the Vassiliev-Kontsevich theorem in a way convenient for calculating the invariants themselves, not only the dimension of the space of the invariants. No prerequisites are required; we give rigorous definitions of the main notions in a way not obstructing intuitive understanding.
\end{abstract}

\section{Contents}

1 Main definitions and results on knots

2 Main definitions and results on links

3 Some basic tools

4 The Gauss linking number modulo 2 via plane diagrams

5 The Arf invariant

6 Appendix: proper colorings 10

7 Oriented knots and links and their connected sums 10

8 The Gauss linking number via plane diagrams 13

9 The Casson invariant $\quad 15$

10 Alexander-Conway polynomial 15

11 Vassiliev-Goussarov invariants 16

12 Appendix: some details 18

${ }^{*}$ I am grateful to A. Enne who prepared the figures and a post-production version of [EEF], and to S. Chmutov, D. Eliseev, A. Enne, M. Fedorov, A. Glebov, N. Khoroshavkina, E. Morozov, A. Ryabichev, A. Sossinsky and R. Živaljević for useful discussions and our work on EEF]. This text is based on lectures at Independent University of Moscow (including Math in Moscow Program) and Moscow Institute of Physics and Technology, and on EEF].

†https://users.mccme.ru/skopenko, Moscow Institute of Physics and Technology, Independent University of Moscow. Supported in part by the Russian Foundation for Basic Research Grant No. 19-01-00169 and by Simons-IUM Fellowship. 
On the style of this text

Usually I formulate a beautiful or important statement before giving a sequence of definitions and results which constitute its proof. In this case, in order to prove this statement, one may need to read some of the subsequent material. I give hints on that after the statements (but I do not want to deprive you of the pleasure of finding the right moment when you finally are ready to prove the statement). Some theorems are presented without proof, so I give references instead of hints.

In this text assertions are simple parts of a theory (for a reader already familiar with part of the material they are quick reminders). For the same reason a small number of problems is presented. For assertions and problems hints or solutions are presented in \$12, together with proofs of theorems and lemmas. However, a reader is recommended to prove assertions (and to solve problems) himself/herself. In order to get a thorough understanding of the material a reader can also consider theorems and lemmas as problems (beware the previous paragraph!). This is peculiar not only to Zen monasteries but also to serious mathematical education, see [HC19, §1.1], Sk20m, §1.2].

Remarks are formally not used later.

\section{Main definitions and results on knots}

We start with informal description of the main notions (rigorous definitions are given after remark 1.2). You can imagine a knot as a thin elastic string whose ends have been glued together, see fig. 1. As in this figure, knots are usually represented by their 'nice' plane projections called knot diagrams. Imagine laying down the rope on a table and carefully recording how it crosses itself (i.e. which part lies on top of the other). It should be kept in mind that the projections of the same knot on different planes can look quite dissimilar.

A trivial knot is the outline (the boundary) of a triangle.
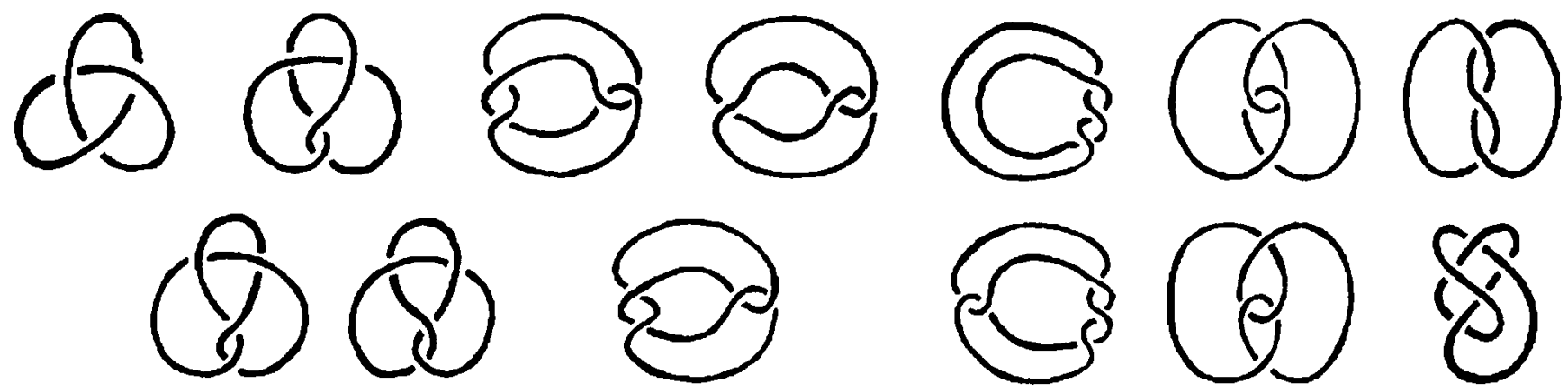

Figure 1: Knots isotopic to the trefoil knot (top row) and to the figure eight knot (bottom row)

By an isotopy of a knot we mean its continuous deformation in space as a thin elastic string; no self-intersections are allowed throughout the deformation. Two knots are isotopic if one can be transformed to the other by an isotopy.

Assertion 1.1. (a) All the knots represented in the top row of fig. 1 are isotopic to each other. (For one pair of these knots decompose your isotopy into Reidemeister moves shown in fig. 9.)

(b) The same is true for the knots represented in the bottom row of fig. 1 .

(c) All knots with the same knot diagram are isotopic.

Remark 1.2 (why a rigorous definition of isotopy is necessary?). In fig. [ we see an isotopy between the trefoil knot and the trivial knot. 


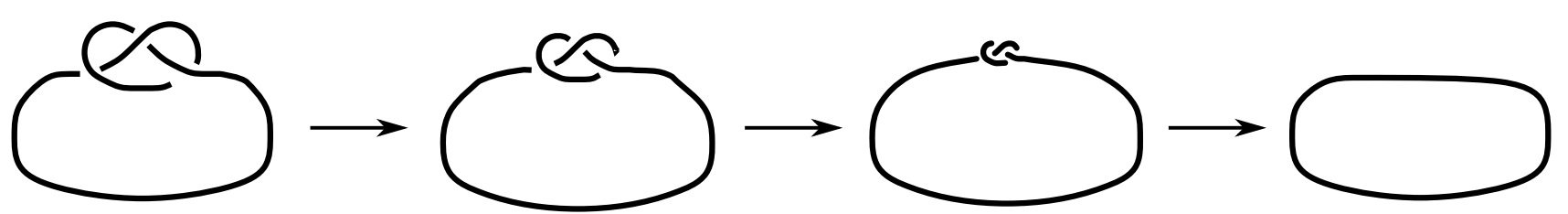

Figure 2: A (non-ambient) isotopy between the trefoil knot and the trivial knot

Is it indeed an isotopy? This is the so called 'piecewise linear non-ambient isotopy', which is different from the 'piecewise linear ambient isotopy' defined and used later. (The first notion better reflects the idea of continuous deformation without self-intersections, but is hardly accessible to high school students, cf. [Sk16i].) In fact, any two knots are piecewise linear non-ambient isotopic!

A usual problem with intuitive definitions is not that it is hard to make them rigorous, but that this can be done in different non-equivalent ways.

A knot is a spatial closed non-self-intersecting polygonal line 1

A plane diagram of a knot is its generid 2 projection onto a plan 3 , together with the information which part of the knot 'goes under' and which part 'goes over' at any given crossing.

Assertion 1.3. For any knot diagram there is a knot projected to this diagram. (Such a knot need not be unique; see though assertion 1.1.c.)

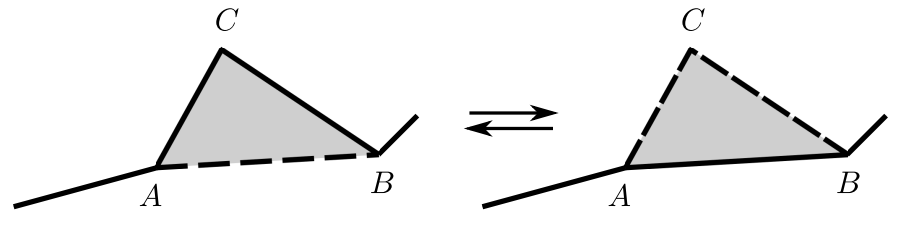

Figure 3: Elementary move

Suppose that two sides $A C$ and $C B$ of a triangle $A B C$ are edges of a knot. Moreover, assume that the knot and (the part of the plane bounded by) the triangle $A B C$ do not intersect at any other points. An elementary move $A C B \rightarrow A B$ is the replacement of the two edges $A C$ and $C B$ by the edge $A B$, or the inverse operation $A B \rightarrow A C B$ (fig. 3) 4 Two knots $K$ and $L$ are called (piecewise linearly ambiently) isotopic if there is a sequence of knots $K_{1}, \ldots, K_{n}$ such that $K_{1}=K, K_{n}=L$ and every subsequent knot $K_{j+1}$ is obtained from the previous one $K_{j}$ by an elementary move.

Theorem 1.4. (a) The following knots are pairwise not isotopic: the trivial knot, the trefoil knot, the figure eight knot.

(b) There is an infinite number of pairwise non-isotopic knots.

This is proved using Arf and Casson invariants, see \$5 and \$9, cf. \$6.

The mirror image of a knot $K$ is the knot whose diagram is obtained by changing all the crossings (fig. 8) in a diagram of $K$. By assertion 1.1.b the figure eight knot is isotopic to its mirror image.

Theorem 1.5. The trefoil knot is not isotopic to its mirror image.

\footnotetext{
${ }^{1}$ This is not to be confused with oriented knot defined below in $\$ 7$

${ }^{2} \mathrm{~A}$ polygonal line in the plane is generic if there is a polygonal line $L$ with the same union of edges such that no 3 vertices of $L$ belong to any line and no 3 segments joining some vertices of $L$ have a common interior point.

${ }^{3} \mathrm{~A}$ university-mathematics terminology is 'a generic image under projection onto a plane'.

${ }^{4}$ If the triangle $A B C$ is degenerate, then elementary move is either subdivision of an edge or inverse operation.
} 
Theorem 1.5 is proved using the Jones polynomial [PS96, §3], [CDM, §2.4]. The proof is outside the scope of this text.

Theorem 1.6 (Conway-Gordon; cf. [CG83, Theorem 2]). Take any 7 points in 3-space, no four of which belong to any plane. Take $\left(\begin{array}{l}7 \\ 2\end{array}\right)=21$ segments joining them. Then there is a closed polygonal line formed by taken segments and non-isotopic to the boundary of a triangle.

This is proved using Arf invariant, see \$5. The details are outside the scope of this text.

\section{Main definitions and results on links}

A link is a collection of pairwise disjoint knots, which are called the components of the link. Ordered collections are called ordered or colored links, while non-ordered collections are called non-ordered or non-colored links. In this text we abbreviate 'ordered link' to just 'link'.

A trivial link (with any number of components) is a link formed by triangles in parallel planes.

Plane diagrams and isotopy for links are defined analogously to knots.

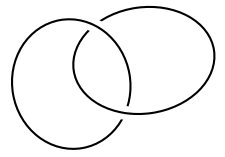

(a)

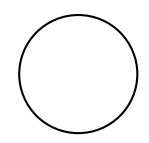

(b)

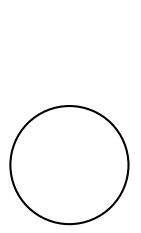

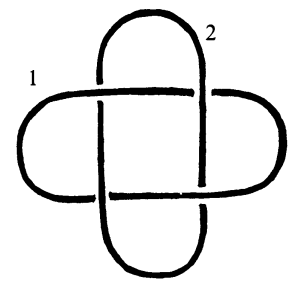

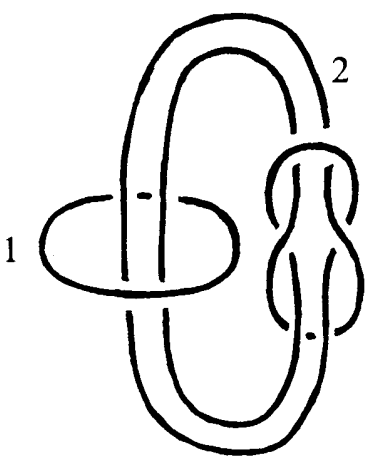

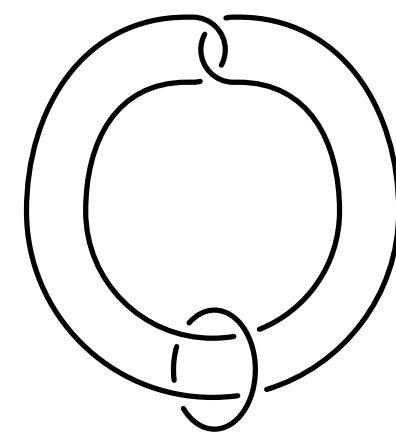

Figure 4: The Hopf link, the trivial link and another three links

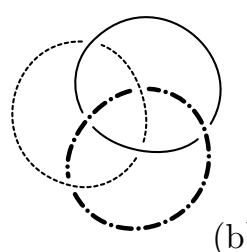

(b)

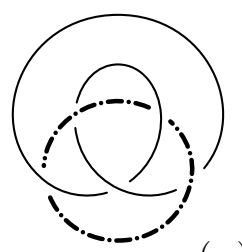

(w)

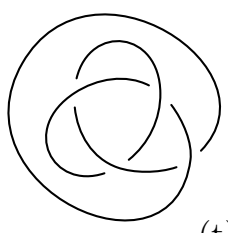

$(\mathrm{t})$

Figure 5: The Borromean rings, the Whitehead link and the trefoil knot

Assertion 2.1. (a) The Hopf link is isotopic to the link obtained from the Hopf link by switching the components.

(b) The Hopf link is isotopic to some link whose components are symmetric with respect to some straight line. 
(c) The fourth link in fig. 4 is isotopic to the Whitehead link in fig. 5.w.

(d,e) The same as in $(a, b)$ for the Whitehead link.

(f) The Borromean rings link is isotopic to a link whose components are permuted in a cyclic way under the rotation by angle $2 \pi / 3$ with respect to some straight line.

Proof. (a) This follows by (b) (or can be proved independently).

(d) This follows by (e) (or can be proved independently).
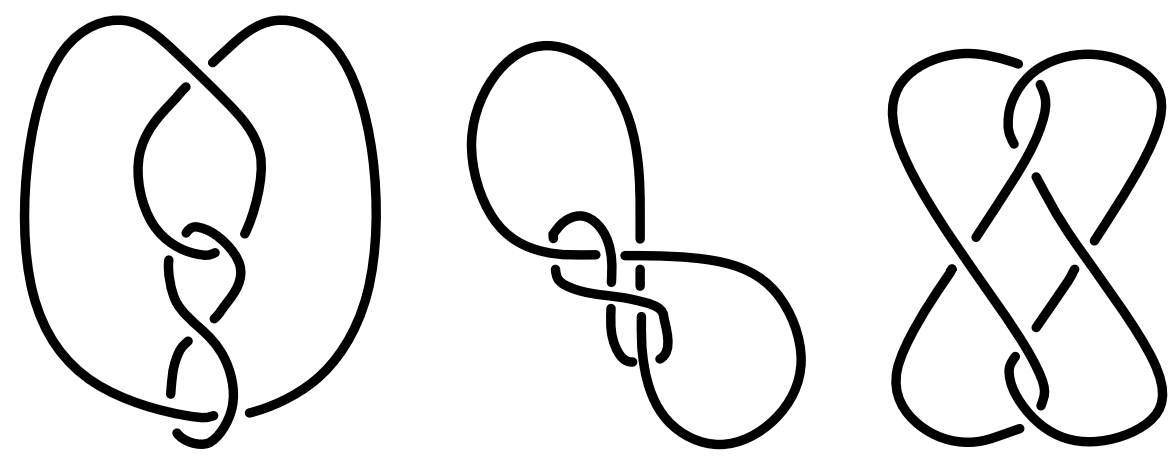

Figure 6: Isotopy of the Whitehead link

(e) See figure 6.

(f) Take the quadrilaterals from figure 7, left. Then the straight line is the bisector of any octant formed by the quadrilaterals.
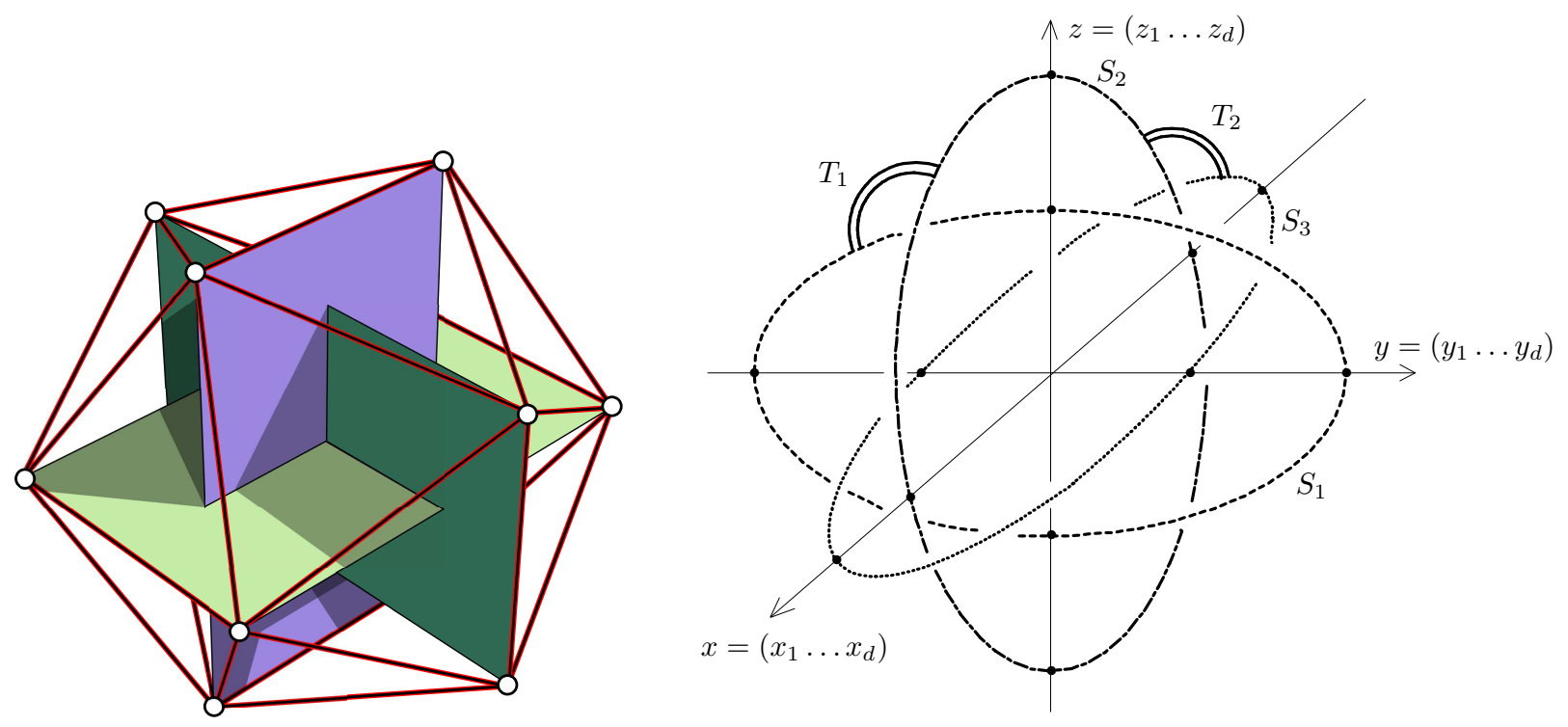

Figure 7: Borromean rings

There is also the following beautiful curvilinear construction. Take three ellipses given by the following three systems of equations:

$$
\left\{\begin{array}{c}
x=0 \\
y^{2}+2 z^{2}=1
\end{array}, \quad\left\{\begin{array} { c } 
{ y = 0 } \\
{ z ^ { 2 } + 2 x ^ { 2 } = 1 }
\end{array} \quad \text { and } \quad \left\{\begin{array}{c}
z=0 \\
x^{2}+2 y^{2}=1 .
\end{array}\right.\right.\right.
$$

See figure 7, right. Then the straight line is given by $x=y=z$.

Theorem 2.2. (a) The following links are pairwise non-isotopic: the Hopf link, the trivial link, the Whitehead link.

(b) The Borromean rings link is not isotopic to the trivial link. 
This is proved using linking number modulo 2, invent it yourself or see $\$ 4$, and the AlexanderConway polynomials, see \$10. Alternatively, one can use the 'triple linking' (Massey-Milnor) number and 'higher linking' (Sato-Levine) number [Sk, §4.4-§4.6].

Theorem 2.3 (Conway-Gordon, Sachs; [Sk14, Theorem 1.1], cf. [CG83, Theorem 1]). If no 4 of 6 points in 3-space lie in the same plane, then there are two linked triangles with vertices at these 6 points. That is, the part of the plane bounded by the first triangle intersects the outline of the second triangle exactly at one point.

This is proved using linking number modulo 2, see \$4. The details are outside the scope of this text, see [Sk14].

\section{Some basic tools}

Remark 3.1 (some accurate arguments). In the following paragraph we prove that if a knot lies in a plane, then the knot is isotopic to the trivial knot.

Denote the knot in a plane by $M_{1} M_{2} \ldots M_{n}$. Take a point $Z$ outside the plane. Then $M_{1} M_{2} \ldots M_{n}$ is transformed to the trivial knot $M_{1} Z M_{n}$ by the following sequence of elementary moves:

$$
M_{1} M_{2} \rightarrow M_{1} Z M_{2}, \quad Z M_{2} M_{3} \rightarrow Z M_{3}, \quad Z M_{3} M_{4} \rightarrow Z M_{4}, \quad \ldots, \quad Z M_{n-1} M_{n} \rightarrow Z M_{n}
$$

The following result shows that intermediate knots of an isotopy from a knot lying in a plane to the trivial knot can be chosen also to lie in this plane.

Schoenflies theorem. Any closed polygonal line without self-intersections in the plane is isotopic (in the plane) to a triangle.

This is a stronger version of the following celebrated result.

Jordan theorem. Every closed non-self-intersecting polygonal line $L$ in the plane $\mathbb{R}^{2}$ splits the plane into exactly two parts, i.e. $\mathbb{R}^{2}-L$ is not connected and is a union of two connected sets.

A subset of the plane is called connected if every two points of this subset can be connected by a polygonal line lying in this subset.

For an algorithmic explanation why the Jordan Theorem (and so the Schoenflies Theorem) is non-trivial, and for a proof of the Jordan Theorem, see $\$ 1.3$ 'Intersection number for polygonal lines in the plane' of [Sk18], [Sk].

Assertion 3.2. Suppose that there is a point on a knot such that if we go around the knot starting from this point, then on some plane diagram we first meet only overcrossings, and then only undercrossings. Then the knot is isotopic to the trivial knot:5

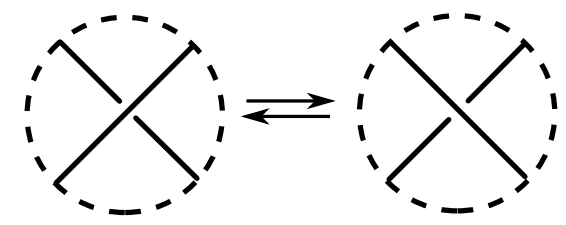

Figure 8: Crossing change. The plane diagrams are identical outside the disks bounded by dashed circles. No other sides of the plane diagrams except for the pictured ones intersect the disks. (Same for fig. 9, 10, 11, 12 and 21,)

\footnotetext{
${ }^{5}$ This assertion would be a motivation for introduction of the Arf invariant ( $\$ 5$ ). The proof illustrates in low dimensions one of the main ideas of the celebrated Zeeman's proof of the higher-dimensional Unknotting Spheres Theorem, see the survey [Sk16c, Theorem 2.3].
} 
A crossing change is change of overcrossing to undercrossing or vise versa, see fig. 8.

Clearly, after any crossing change on the leftmost diagrams of the trefoil knot and the figure eight shown in fig. 1 we obtain a diagram of a knot isotopic to the trivial knot.

Lemma 3.3. Every plane diagram of a knot can be transformed by crossing changes to a plane diagram of a knot isotopic to the trivial knot 6
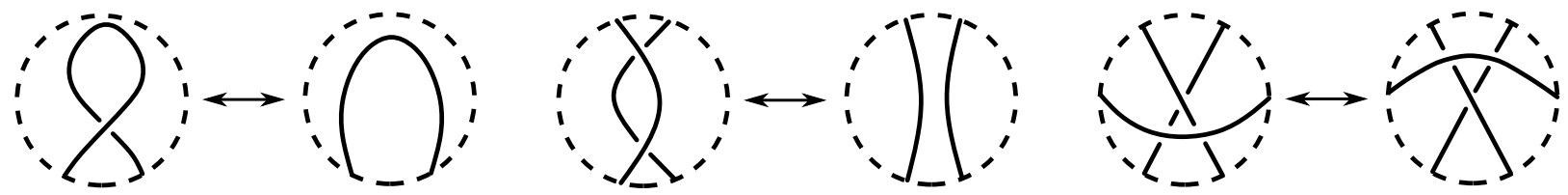

Figure 9: Reidemeister moves
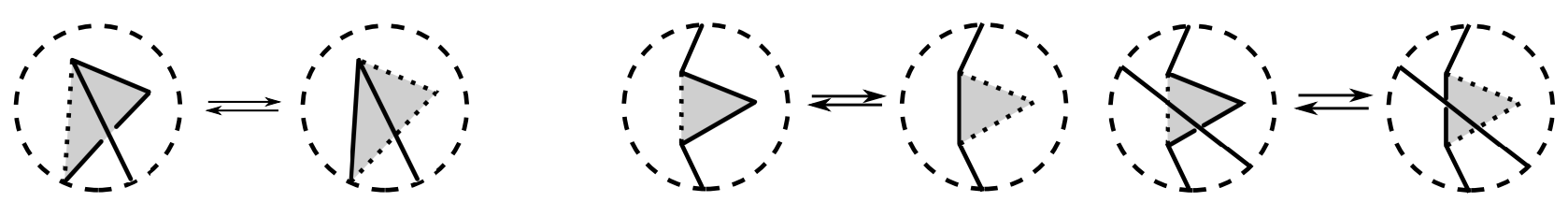

Figure 10: Left: to a rigorous definition of the first Reidemeister move Middle, right: plane isotopy moves

In this text instead of knots up to isotopy we shall study plane diagrams of knots up to (equivalence generated by) Reidemeister moves (shown in fig. 9) $)^{7}$ and plane isotopy moves shown in fig. 10 (middle, right). I.e. we shall use without proof the following result.

Theorem 3.4 (Reidemeister). Two knots are isotopic if and only if some plane diagram of the first knot can be obtained from some plane diagram of the second one by Reidemeister moves and plane isotopy moves.

See [PS96, $\$ 1.7], 8$ The analogues of lemma 3.3 and theorem 3.4 for links are correct.

\footnotetext{
${ }^{6}$ This simple lemma will be used for construction of invariants using recursive (skein) relations, see 4.4 , 5.44 .49 .410 .2 11.1

${ }^{7}$ A rigorous definition of the first Reidemeister move is easily given using fig. 10 (left). The other Reidemeister moves have analogous rigorous definitions. You can use informal description of Reidemeister moves in fig. 9] and so ignore plane isotopy moves. See footnote 8

${ }^{8}$ Since [PS96, §1.6] does not contain as rigorous definition of Reidemeister moves as that of plane isotopies, the argument in [PS96, §1.7] does not constitute a rigorous proof. We believe that a rigorous proof can be recovered using rigorous definition of Reidemeister moves.

This shows that having plane isotopy in the statement [PS96, §1.7] does not make the statement rigorous, and thus should be avoided. On an intuitive level, plane isotopies should better be ignored. With the alternative rigorous definition below, plane isotopies can be expressed via Reidemeister moves and so again should better be ignored in the statement.

Let us present an alternative rigorous definition of the first Reidemeister move. The other Reidemeister moves have analogous rigorous definitions. On the plane take a closed non-self-intersecting polygonal line $L$ whose interior (see the Jordan theorem in remark 3.1) intersects a knot diagram $D$ by a non-self-intersecting polygonal line $M$ joining two points on $L$. Let $N$ be a closed non-self-intersecting polygonal line in the interior of $L$ such that $N \cap L=\emptyset$, $N \cap M$ is one point and $M \cup N$ is a generic (self-intersecting) polygonal line. The first Reidemeister move is replacement of $M$ to $M \cup N$ in $D$, with any 'information' at the appearing crossing.
} 


\section{The Gauss linking number modulo 2 via plane diagrams}

Suppose that there is an isotopy between two 2-component links, and the second component is fixed throughout the isotopy. Then the trace of the first component is a self-intersecting cylinder disjoint from the second component. If after the isotopy the components are unlinked, then the cylinder can be completed to a self-intersecting disk disjoint from the second component. This observation, together with [Sk, the Projection lemma 4.3.2], motivates the following definition.

The linking number modulo two $\mathrm{lk}_{2}$ of the plane diagram of a 2-component link is the number modulo 2 of crossing points on the diagram at which the first component passes above the second component.

Problem 4.1. Find the linking number modulo 2 for the plane diagrams in fig. 4 and for pairs of Borromean rings in fig. 5.b.

Lemma 4.2. The linking number modulo 2 is preserved under Reidemeister moves.

This lemma is easily proved separately for every Reidemeister move.

By lemma 4.2 the linking number modulo 2 of a 2-component link (or even of its isotopy class) is well-defined by setting it to be the linking number modulo 2 of any plane diagram of the link.

We shall use without proof the following Parity lemma: any two closed polygonal lines in the plane whose vertices are in general position intersect at an even number of points. For a discussion and a proof see $\$ 1.3$ 'Intersection number for polygonal lines in the plane' of [Sk18, Sk].

Assertion 4.3. (a) Switching the components of a 2-component link preserves the linking number modulo 2.

(b) There is a 2-component link which is not isotopic to the trivial link but whose linking number modulo 2 is zero.

Part (b) is proved using integer-valued linking coefficient, see $\$ 8$.

Theorem 4.4. There is a unique mod2-valued isotopy invariant $\mathrm{lk}_{2}$ of 2-component links that assumes value 0 on the trivial link and such that for any links $K_{+}$and $K_{-}$whose plane diagrams differ by a crossing change of a crossing $A$

$$
\mathrm{lk}_{2} K_{+}-\mathrm{lk}_{2} K_{-}= \begin{cases}1 & A \text { is the crossing of different components } \\ 0 & A \text { is the self-crossing of one component }\end{cases}
$$

Assertion 4.5. If the linking number modulo 2 of two (disjoint outlines of) triangles in space is zero, then the link formed by the triangles is isotopic to the trivial link.

The proof is presumably unpublished but not hard. We encourage a reader to publish the details. Cf. [Ko19].

\section{The Arf invariant}

Take a plane diagram of a knot and a point $P$ on the diagram different from crossing points. Call $P$ a basepoint. A non-ordered pair of crossing points $A$ and $B$ is called skew (or $P$-skew) if going around the diagram in some direction starting from $P$ and marking only crossings at $A$ and $B$, we first mark overcrossing at $A$, then undercrossing at $B$, then undercrossing at $A$, and at last overcrossing at $B$. The $P$-Arf invariant of the plane diagram is the parity of the number of all skew pairs of crossing points. 
Problem 5.1. (a) If the P-Arf invariant of a plane diagram is non-zero, then $P$ is not a point as in assertion 3.2.

(b) Find the P-Arf invariant (of some plane diagram) of the trivial, the trefoil and the figure eight knots (for arbitrary choice of a basepoint $P$ ).

Lemma 5.2. (a) The P-Arf invariant is independent of the choice of a basepoint P.

(b) The Arf invariant of a plane diagram is preserved under Reidemeister moves.

By (a) the Arf invariant of a plane diagram is well-defined by setting it to be the P-Arf invariant for any basepoint $P$. So the statement of (b) makes sense. By (b) the Arf invariant (Arf number) arf of a knot (or even of isotopy class of a knot) is well-defined by setting it to be the Arf invariant of any plane diagram of the knot.

Hints. (a) It suffices to show that the Arf invariant remains unchanged when the basepoint moves through one crossing on the plane diagram.

(b) Prove the statement for each Reidemeister move separately. Cleverly choose a basepoint!

Assertion 5.3. There is a knot which is not isotopic to the trivial knot but which has zero Arf invariant.

This is proved using Casson invariant, see $\$ 9$,
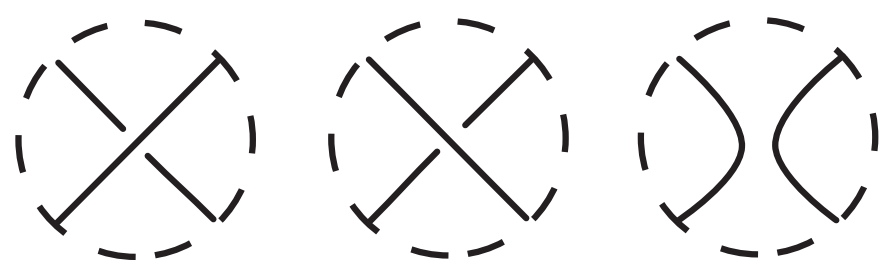

Figure 11: Links $K_{+}, K_{-}, K_{0}$

Theorem 5.4. There is a unique mod2-valued isotopy invariant arf of knots that assumes value 0 on the trivial knot and such that

$$
\operatorname{arf} K_{+}-\operatorname{arf} K_{-}=\operatorname{lk}_{2} K_{0} .
$$

for any knots $K_{+}$and $K_{-}$whose plane diagrams differ as shown in fig. 11 so that $K_{0}$ is a 2component link. (The latter is equivalent to the existence of the orientation for which fig. 11 becomes fig. 21.)

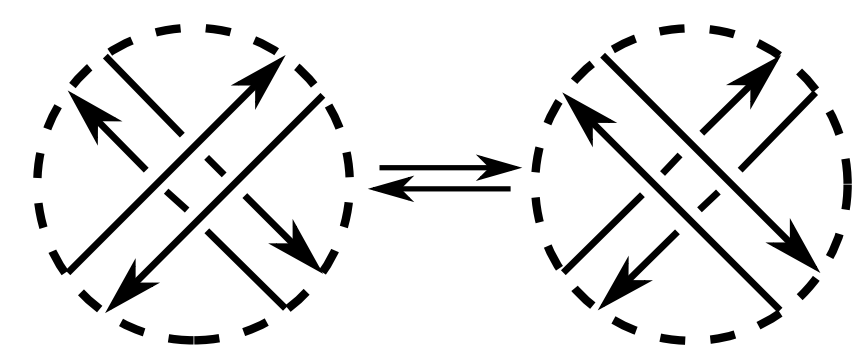

Figure 12: Pass move

Assertion 5.5. Two knots are called pass equivalent if some plane diagram of the first knot (with some orientation) can be transformed to some plane diagram of the second knot (with some orientation) using Reidemeister moves and pass moves of fig. 12.

(a) If two knots are pass equivalent, then their Arf invariants are equal.

(b) The eight figure knot is pass equivalent to the trefoil knot.

(c) Ka87, pp. 75-78] If the Arf invariants of two knots are equal, then the knots are pass equivalent. 


\section{Appendix: proper colorings}

Section [6 only uses the material of $\$ 1$ and $\$ 2$, See more in [Pr98].

A strand in a plane diagram (of a knot or link) is a connected piece that goes from one undercrossing to the next. A proper coloring of a plane diagram (of a knot or link) is a coloring of its strands in one of three colors so that at least two colors are used, and at each crossing, either all three colors are present or only one color is present. A plane diagram (of a knot or link) is 3-colorable if it has a proper coloring.

Problem 6.1. For each of the following knots or links take any diagram and decide if it is 3colorable.

(a) the trivial knot. (b) the trefoil knot. (c) the figure eight knot.

(d-i) links in fig. 4 and 5 .

Lemma 6.2 ([r95, pp. 29-30, Theorem 4.1]). The 3-colorability of a plane diagram is preserved under the Reidemeister moves.

Theorem 6.3. (a) Neither of links in fig. 4 and 5 (except the trivial link) is isotopic to the trivial link.

(b) The $5_{1}$ knot is not isotopic to the trivial knot.

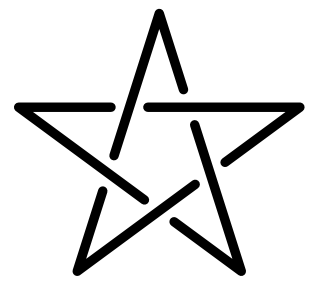

Figure 13: The 5 knot

\section{Oriented knots and links and their connected sums}

One knows what is oriented polygonal line, so one knows what is oriented knot (fig. 14).
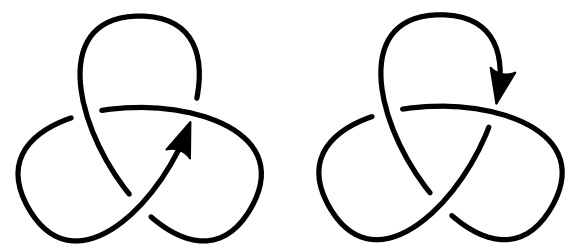

Figure 14: Two trefoil knots with the opposite orientations

Both the informal notion and rigorous definition of isotopic oriented knots are given analogously to isotopic knots.

Assertion 7.1. Isotopic oriented polygonal lines without self-intersections on the plane and on the sphere are defined analogously to isotopic oriented knots in space.

(a) An oriented spherical triangle is isotopic on the sphere to the same triangle with the opposite orientation.

(b) The analogue of (a) for the plane is false. 
Assertion 7.2. The following pairs of knots with opposite orientations are isotopic: two trivial knots, two trefoil knots, two figure eight knots.

Theorem 7.3 (Trotter, 1964). There exists an oriented knot which is not isotopic to the same knot with the opposite orientation.

This is proved using the Jones polynomial [PS96, §3], [CDM, §2.4]; the proof is outside the scope of this text.
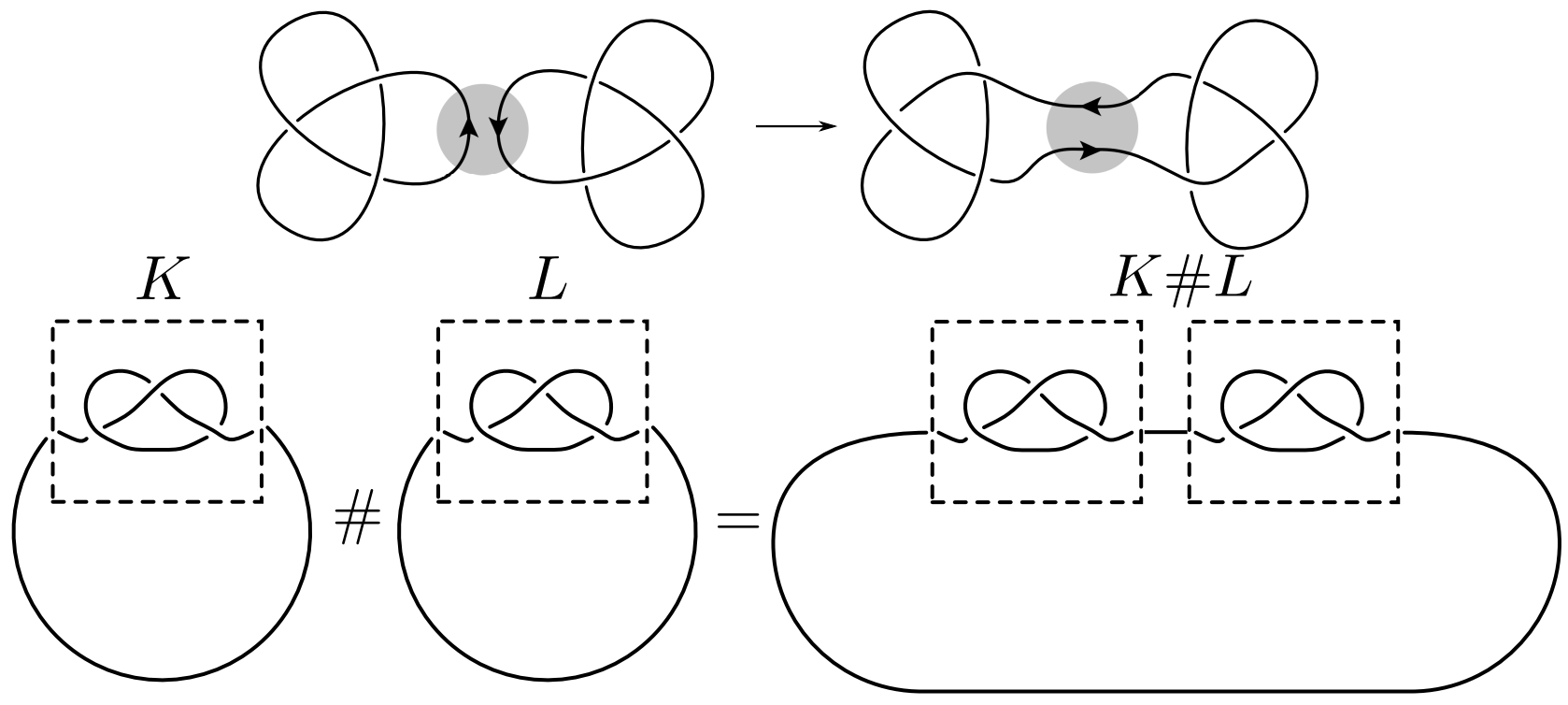

Figure 15: Connected sum of knots

The connected sum \# of oriented knots is defined in fig. 15. The connected sum \# of (non-oriented) knots is defined analogously (just ignore the arrows). Neither operation is welldefined on the set of knots or oriented knots, respectively. So we denote by $K \# L$ any of the connected sums of knots or oriented knots $K$ and $L$.

Assertion 7.4. For any oriented knots $K, L, M$ and the trivial oriented knot $O$ we have

(a) $K \# O=K . \quad$ (b) $K \# L=L \# K . \quad$ (c) $(K \# L) \# M=K \#(L \# M)$.

(d) For any non-oriented knots $K, L$ we have $\operatorname{arf}(K \# L)=\operatorname{arf} K+\operatorname{arf} L$.

(The rigorous meaning of $(a)$ is 'any connected sum of $K$ and $O$ is isotopic to $K$ '. Analogous rigorous meanings have $(b, c)$ and (d). See though remark 7.5.)

Sketch of the proof. (a) See fig. 16.
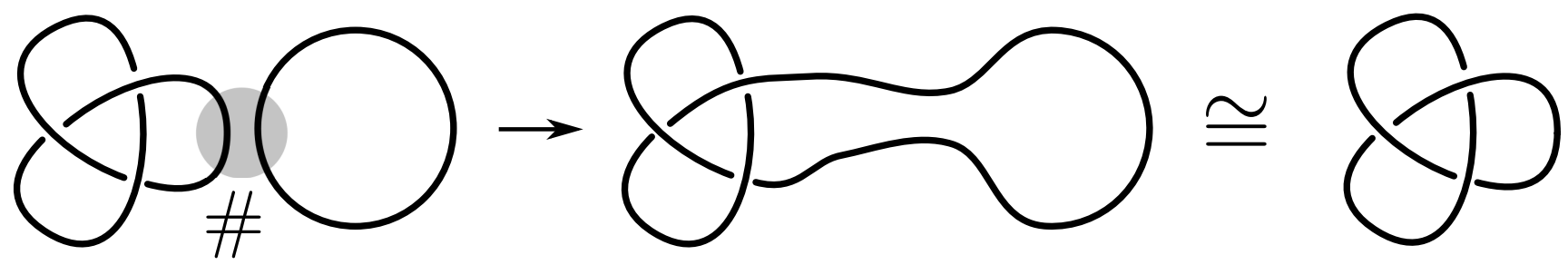

Figure 16: Proof of $K \# O=K$

(b) Take a small knot isotopic to $L$ and push it through $K$, see fig. 17, left.

(c) The left hand and the right hand side of the equality are isotopic to the knot in fig. 17, right.

(d) Choose basepoint close to the 'place of connection'. Check that all skew pairs of crossings in $K \# L$ are obtained from the skew pairs of crossings in $K$ and in $L$. 

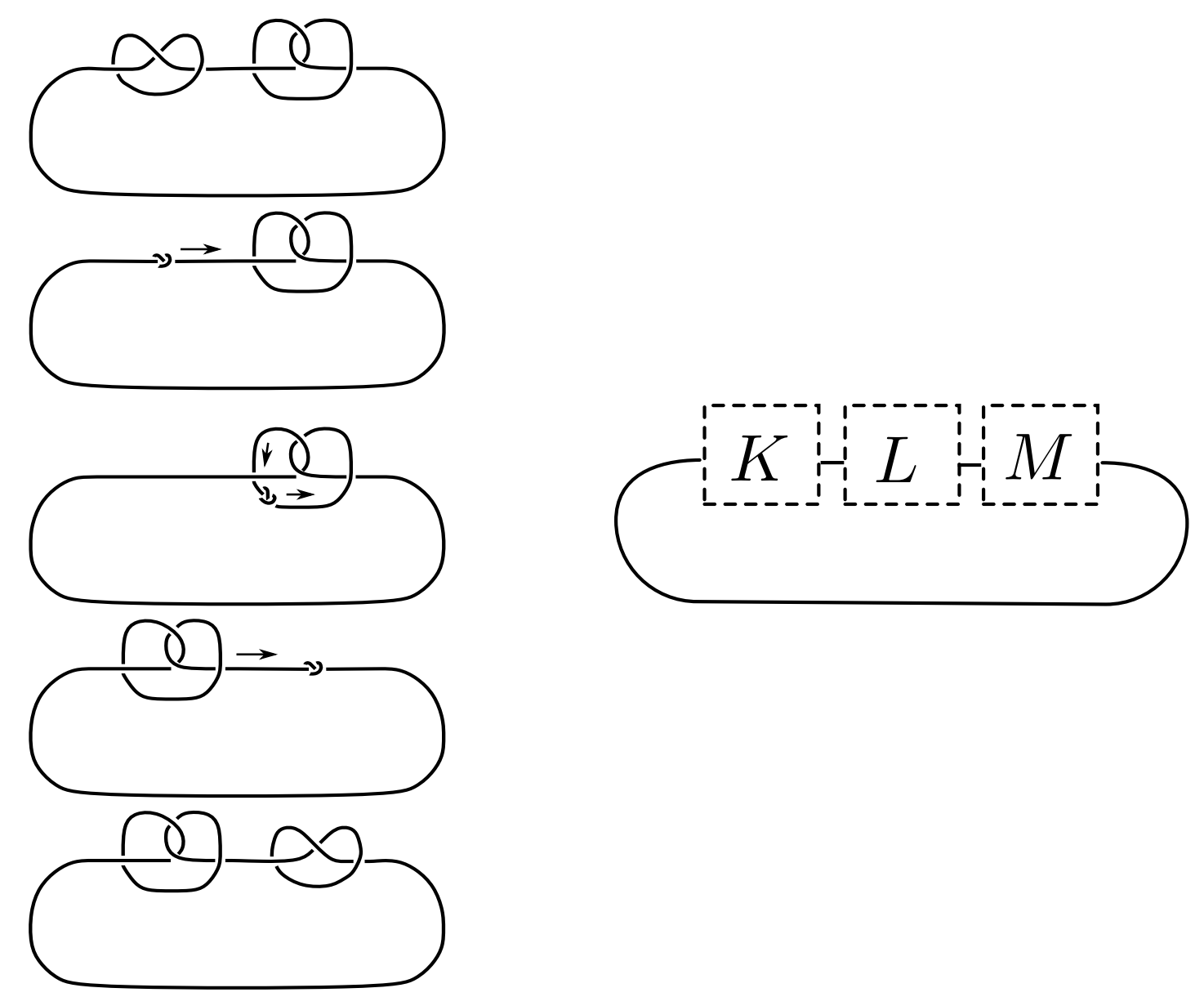

Figure 17: Proofs of $K \# L=L \# K$ and of $(K \# L) \# M=K \#(L \# M)$

Remark 7.5. An isotopy class of a knot is the set of knots isotopic to this knot. The oriented isotopy class $[K \# L]$ of the connected sum of two oriented isotopy classes $[K],[L]$ of oriented knots $K, L$ is independent of the choices used in the construction, and of the representatives $K, L$ of $[K],[L]$. Hence the connected sum of oriented isotopy classes of oriented knots is well-defined by $[K] \#[L]:=[K \# L]$, see [Sk15, Remark 2.3.a]. For isotopy classes of non-oriented knots the connected sum is not well-defined [CSK].

Theorem 7.6. For any isotopy classes $K, L, M$ of knots and the isotopy class $O$ of the trivial oriented knot we have

(a) if $K \# L=O$, then $K=L=O$;

(b) if $K \# L=K \# M$, then $L=M$.

The proof is outside the scope of this text, see [PS96, Theorem 1.5]. (In this part of [PS96] one needs to replace 'knot' by 'oriented knot' because of remark 7.5.)

The connected sum \# of links (ordered or not, oriented or not) is defined analogously to the connected sum of knots, see fig. 18. This is not a well-defined operation on links, and assertion 7.8 shows that this does not give a well-defined operation on their isotopy classes. So we denote by $K \# L$ any of the connected sums of $K$ and $L$.

Assertion 7.7. (a,b,c) The analogues of assertions 7.4. $a, b, c$ for links are true.

(b) For any non-oriented 2-component links $K, L$ we have $\mathrm{lk}_{2}(K \# L)=\mathrm{lk}_{2} K+\mathrm{lk}_{2} L$.

Remark 7.8. There are two isotopic pairs $(K, L)$ and $\left(K^{\prime}, L^{\prime}\right)$ of 2-component links such that some connected sums $K \# L$ and $K^{\prime} \# L^{\prime}$ are not isotopic. (The links could be ordered or nonordered, oriented or non-oriented, so that we have 4 statements.) As an example of non-ordered 

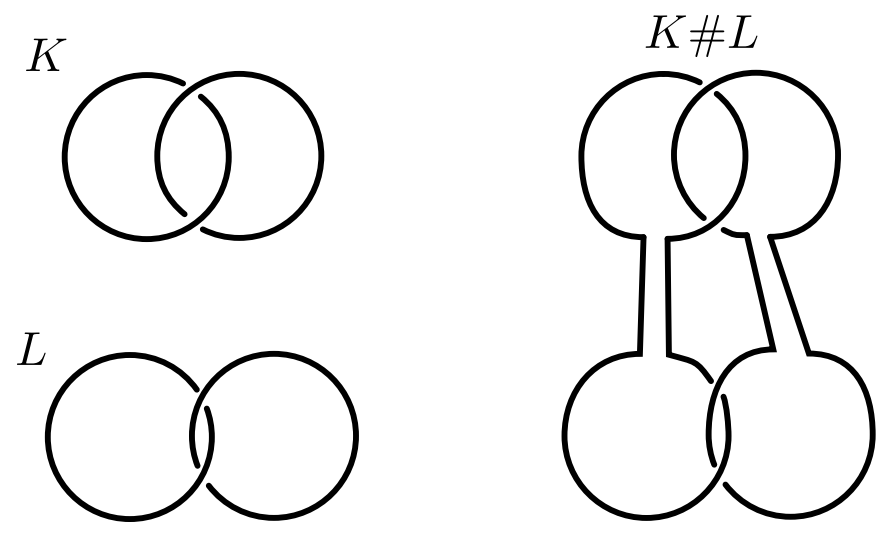

Figure 18: Connected sum of links

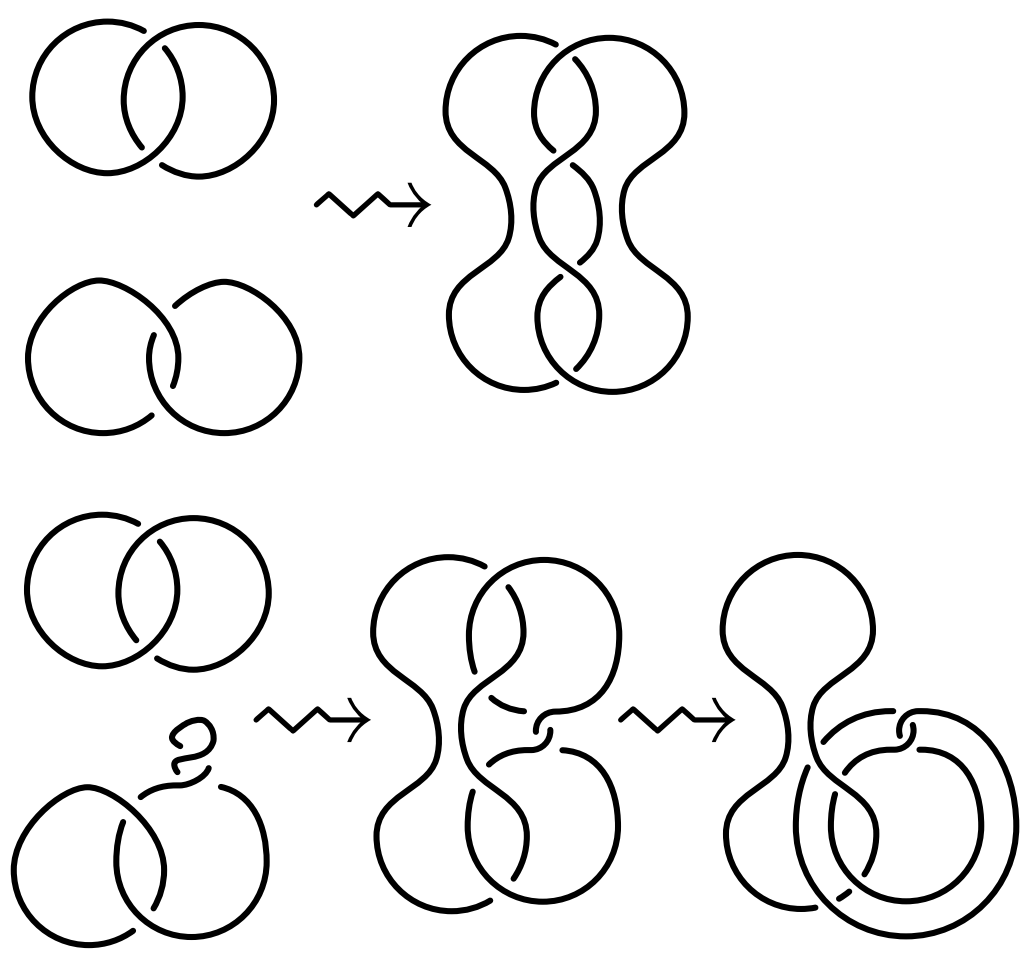

Figure 19: Connected sum of isotopy classes of ordered links is not well-defined

pairs we can take equal links consisting of a trefoil and an unknot in disjoint cubes, cf. [PS96, Figure 3.16]. For an example of ordered pairs see [As]. Fig. 19 presents an alternative example suggested by A. Ryabichev.

\section{The Gauss linking number via plane diagrams}

Let $(\overrightarrow{A B}, \overrightarrow{C D})$ be an ordered pair of vectors (oriented segments) in the plane intersecting at a point $P$. Define the sign of the pair to be +1 if $A B C$ is oriented clockwise and to be -1 otherwise (fig. 201).

The linking number $\mathrm{lk}$ of the plane diagram of an oriented 2-component link is the sum of signs at all those crossing points on the diagram at which the first component passes above the second component. At every crossing point the first (the second) vector is the oriented edge of the first (the second) component. 


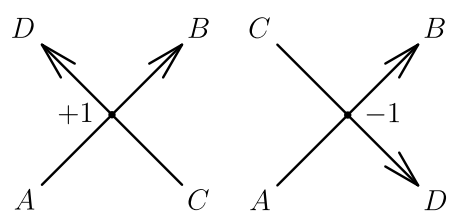

Figure 20: The sign of intersection point

Problem 8.1. Find the linking number for (some plane diagram of) the Hopf link and pairs of Borromean rings, for your choice of orientation on the components.

Lemma 8.2. The linking number is preserved under Reidemeister moves.

The proof is analogous to lemma 4.2. It suffices to check that the signs of all crossing points do not change.

By Lemma 8.2 the linking number of an oriented 2-component link (or of its isotopy class) is well-defined by setting it to be the linking number of any plane diagram of the link.

The absolute value of the linking number of a (non-oriented) 2-component link (or of its isotopy class) is well-defined by taking any orientations on the components.

We shall use without proof the following Triviality lemma: for any two closed oriented polygonal lines in the plane whose vertices are in general position the sum of signs of their intersection points is zero. For a discussion and a proof see $\$ 1.3$ 'Intersection number for polygonal lines in the plane' of [Sk18], $[\mathrm{Sk}]$.

Assertion 8.3. (a) Switching the components of a link negates the linking number.

(b) Reversing the orientation of either of the components negates the linking number.

(c) There is an oriented 2-component link whose linking number is -5 .

(d) For any of the connected sums $K \# L$ of oriented 2-component links $K, L$ we have $\operatorname{lk}(K \# L)=$ lk $K+\mathrm{lk} L$.

(e) There is a 2-component link which is not isotopic to the trivial link but which has zero linking number.

Part (e) is proved using Alexander-Conway polynomial, see $\$ 10$.

Theorem 8.4. There is a unique integer-valued isotopy invariant lk of oriented 2-component links that assumes value 0 on the trivial link and such that for any links $K_{+}$and $K_{-}$whose plane diagrams differ by a crossing change of a crossing $A$ as shown in fig. 21]

$$
\mathrm{lk} K_{+}-\mathrm{lk} K_{-}= \begin{cases}1 & A \text { is the crossing of different components } \\ 0 & A \text { is the self-crossing of one component }\end{cases}
$$

The proof is analogous to theorem 4.4 .

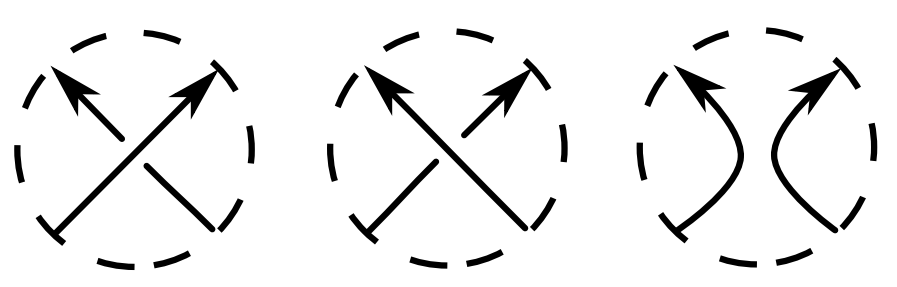

Figure 21: Oriented links $K_{+}, K_{-}, K_{0}$ 


\section{The Casson invariant}

The sign of a crossing point of an oriented plane diagram of a knot is defined after figure 20, the first (the second) vector is the vector of overcrossing (of undercrossing). Clearly, the sign is independent of the orientation of the diagram, and so is defined for non-oriented diagram.

The sign of a $P$-skew pair of crossing points in a plane diagram of a knot (for any basepoint $P)$ is the product of the signs of the two crossing points.

The $P$-Casson invariant of a plane diagram is the sum of signs over all $P$-skew pairs of crossing points.

Problem 9.1. (a) Same as problem 5.1.b for the Casson invariant.

(b) Draw a plane diagram of a knot and a basepoint $P$ such that $P$-Casson invariant is -5 .

Lemma 9.2. (a,b) Same as lemma 5.2. a,b for the Casson invariant.

Hence the Casson invariant (number) $c_{2}$ of a plane diagram, of a knot, or even of isotopy class of a knot, is well-defined by setting it to be the $P$-Casson invariant of any plane diagram of the knot for any basepoint $P$.

Assertion 9.3. (a,b) Same as assertions 7.4.d and 5.3 for the Casson invariant.

Part (b) is proved using Alexander-Conway polynomial, see $\$ 10$.

Denote by $D_{+}, D_{-}, D_{0}$ any three diagrams of oriented (knots or) links differing as shown in fig. 21 (for a convention on figures see caption to fig. 8). We also denote by $K_{+}, K_{-}, K_{0}$ any three links who have diagrams $D_{+}, D_{-}, D_{0}$.

Theorem 9.4. There is a unique integer-valued isotopy invariant $c_{2}$ of (non-oriented) knots that assumes value 0 on the trivial knot and such that for any knots $K_{+}$and $K_{-}$whose plane diagrams differ as shown in fig. 21

$$
c_{2}\left(K_{+}\right)-c_{2}\left(K_{-}\right)=\operatorname{lk} K_{0} .
$$

(Observe that $K_{0}$ has to be a 2-component link; the number lk $K_{0}$ is well-defined because change of the orientation on both components of an oriented link does not change the linking number.)

\section{Alexander-Conway polynomial}

Section 10 only uses the material of $\$ 1$, $\$ 2$ and $\$ 7$ (except that assertions 10.4.bc use $\S 8$ and $\$ 9$ ).

Problem 10.1. (a) There is a unique mod2-valued isotopy invariant arf of oriented 3-component links that assumes value 0 on the trivial link and for which

$$
\operatorname{arf} K_{+}-\operatorname{arf} K_{-}= \begin{cases}\operatorname{lk}_{2} K_{0} & \text { at the crossing point different components cross each other; } \\ 0 & \text { at the crossing point one component crosses itself. }\end{cases}
$$

(Here $\mathrm{lk}_{2} K_{0}$ is defined because $K_{0}$ is a 2-component link. 9

(b) Assuming the existence of the invariant arf from (a), calculate (for your choice of orientation on the components) the arf invariant of the Borromean rings.

\footnotetext{
${ }^{9}$ This assertion is a particular case of $\bmod 2$ version of theorem 10.2 it would be interesting to obtain a direct proof because such a proof could illuminate an idea of proof of theorem 10.2 by presenting the idea in the simplest non-trivial situation.

Theorem 5.4 is the analogue of this assertion for 1-component links (knots). The definition of arf given in $\$ 5$ applies to knots only and here the point is to extend it to 3-component links.
} 
Theorem 10.2. There is a unique infinite sequence $c_{-1}=0, c_{0}, c_{1}, c_{2}, \ldots$ of $\mathbb{Z}$-valued isotopy invariants of oriented non-ordered links such that

- $c_{0}=1$ and $c_{1}=c_{2}=\ldots=0$ for the trivial knot;

- for any $n \geq 0$ and links $K_{+}, K_{-}, K_{0}$ from fig. 21 we have

$$
c_{n}\left(K_{+}\right)-c_{n}\left(K_{-}\right)=c_{n-1}\left(K_{0}\right)
$$

Proofs of the existence in assertion 10.1, a and in theorem 10.2 are outside the scope of this text. We shall use the existence without proof 10 See a proof in [Al28], [Ka06], §3-§5], [Ka06], [Ma18, §5.5 and §5.6], Ga20]. For a relation to proper colorings see [Ka06’, §6].

The polynomial $C(K)(t):=c_{0}(K)+c_{1}(K) t+c_{2}(K) t^{2}+\ldots$ is called the Conway polynomial, see assertion 10.4.e. Introduction of this polynomial allows to calculate all the invariants $c_{n}$ as quickly as one of them. The formula in theorem 10.2 is equivalent to

$$
C\left(K_{+}\right)-C\left(K_{-}\right)=t C\left(K_{0}\right)
$$

Problem 10.3. Calculate the Conway polynomial of the following links (for your choice of orientation on the components).

(a) the trivial link with 2 components; (b) the trivial link with $n$ components;

(c) the Hopf link; (d) the trefoil knot; (e) the figure eight knot;

(f) the Whitehead link; (g) the Borromean rings; (h) the $5_{1}$ knot.

Assertion 10.4. (a) We have $c_{0}(K)=1$ if $K$ is a knot and $c_{0}(K)=0$ otherwise (i.e. if $K$ has more than one component).

(b) For a knot $K$ we have $c_{2 j+1}(K)=0$ and $c_{2}$ is the Casson invariant.

(c) For a 2-component link $K$ we have $c_{2 j}(K)=0$ and $c_{1}$ is the linking coefficient.

(d) For a $k$-component link $K$ we have $c_{j}(K)=0$ if either $j \leq k-2$ or $j-k$ is even.

(e) For every knot or link all but a finitely many of the invariants $c_{n}$ are zeroes.

Assertion 10.5. (a) Change of the orientations of all components of a link (in particular, change of the orientation of a knot) preserves the Conway polynomial.

(b) [CDM, 2.3.4] There is a 2-component link such that change of the orientation of its one component changes the degree of the Conway polynomial (so this change neither preserves nor negates the Conway polynomial).

(c) For any of the connected sums $K \# L$ of knots $K, L$ we have $C(K \# L)=C(K) C(L)$.

Assertion 10.6. A link is split if it is isotopic to a link whose components are contained in disjoint balls.

(a) Neither Hopf link nor Whitehead link nor Borromean rings link is split.

(b) The linking coefficient of a split link is zero.

(c) The Conway polynomial of a split link is zero.

\section{Vassiliev-Goussarov invariants}

Section 11 only uses the material of $\$ 1, \$ 2$ and $\$ 7$ (except that problem 11.3,2 uses $\$ 9$ ).

An (oriented) singular knot is a closed oriented polygonal line in $\mathbb{R}^{3}$ whose only self-intersections are double points which are not vertices. Two singular knots are isotopic if there is an orientation preserving PL homeomorphism $h: \mathbb{R}^{3} \rightarrow \mathbb{R}^{3}$ carrying the first singular knot to the second one,

\footnotetext{
${ }^{10} \mathrm{It}$ is not clear whether the statement in [CDM, §2.3.1] involves ordered or non-ordered links. We deduce the stronger version (for non-ordered links) from the weaker version (for ordered links) in \$12.
} 
and the orientation on the first singular knot to the orientation on the second one. Denote by $\Sigma$ the set of all isotopy classes of singular knots.

A chord diagram is a cyclic word of length $2 n$ having $n$ letters, each letter appearing twice. A chord diagram is depicted as an oriented circle with a collection of chords, cf. [Sk20, §1.5]. For a singular knot $K$ denote by $\sigma(K)$ the following chord diagram. Move uniformly along the oriented circle and for any point $A$ on the circle take the 'corresponding' point $f(A)$ on $K$. Join by a chord each pair of points on the circle corresponding to the intersection point of $K$ [PS96, 4.8], [CDM, 3.4.1] 11

$\lambda$

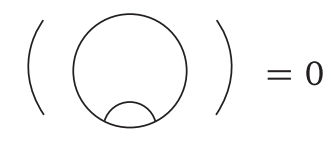

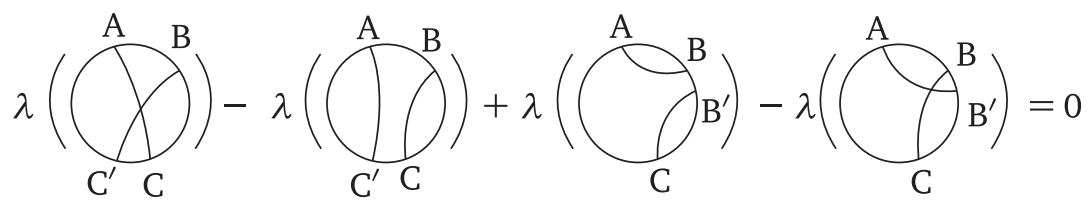

Figure 22: The 1-term and 4-term relations

Theorem 11.1. Assume that $n \geq 0$ is an integer and $\lambda: \delta_{n} \rightarrow \mathbb{R}$ a map from the set $\delta_{n}$ of all chord diagrams that have $n$ chords. The map $\lambda$ satisfies the 1-term and the 4-term relations from fig. 22 if and only if there exists a map $v: \Sigma \rightarrow \mathbb{R}$ (i.e. an invariant of singular knots) such that

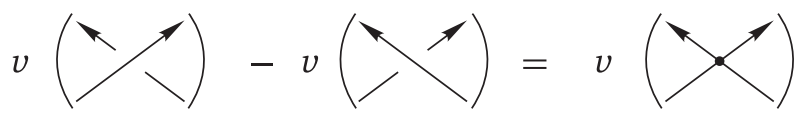

Figure 23: The Vassiliev skein relation, notice the difference with fig. 21

(1) The Vassiliev skein relation from fig. 23 holds,

$\left(2_{n}\right) v(K)=0$ for each singular knot that has more than $n$ self-intersection points, and

(3) $v(K)=\lambda(\sigma(K))$ for each singular knot $K$ that has exactly $n$ self-intersection points.

The proof is outside the scope of this text.

As far as I know, the Vassiliev-Kontsevich theorem 11.1 was never stated in this form, which is short and convenient for calculation of the invariants (although this form was implicitly used when the invariants were calculated). I am grateful to S. Chmutov for confirmation that theorem 11.1 is correct and is indeed equivalent to the standard formulation of the Vassiliev-Kontsevich theorem, see e.g. [CDM, Theorem 4.2.1], cf. [PS96, Theorem 4.12].

A map $v: \Sigma \rightarrow \mathbb{R}$ such that (1) holds is called a Vassiliev-Goussarov invariant. If additionally $\left(2_{n}\right)$ holds, then $v$ is called a invariant of order at most $n$. The following assertion shows that the map $v$ of theorem [11.1 is unique up to Vassiliev-Goussarov invariant of order at most $n-1$.

Assertion 11.2 ([CDM, Proposition 3.4.2]). The difference between maps $v, v^{\prime}: \Sigma \rightarrow \mathbb{R}$ satisfying to (1), $\left(2_{n}\right)$ and (3), satisfies to (1) and $\left(2_{n-1}\right)$.

Problem 11.3. (a) Prove the 'if' part of theorem 11.1.

(0),(1),(2) Prove the 'only if' part of theorem 11.1 for $n=0,1,2$.

Hint. For $n=2$ use theorem 9.4.

(The 'only if' part of theorem 11.1 for $n=3$ could be proved using the coefficient of $h^{3}$ in $J\left(e^{h}\right)$, where $J$ is the Jones polynomial in t-parametrization [CDM, 2.4.2, 2.4.3] [PS96, (4.6)].)

\footnotetext{
${ }^{11}$ In other words, take a PL map $f: S^{1} \rightarrow \mathbb{R}^{3}$ of the circle whose image is $K$. Take a chord $X Y$ for each pair of points $X, Y$ such that $f(X)=f(Y)$. A chord diagram should not be confused with the Gauss diagram (of a projection) of a (non-singular) knot $g: S^{1} \rightarrow \mathbb{R}^{3}$ which is the (somehow oriented) chord diagram of the composition of the projection $\mathbb{R}^{3} \rightarrow \mathbb{R}^{2}$ and $g$ [PS96, 4.8] [CDM, 1.8.4].
} 
In the remaining problems use (the 'only if' part of) theorem 11.1 without proof. Assertion ' $v(K)=x$ for any singular knot $K$ whose chord diagram is $A$ ' is shortened to ' $v(A)=x$ '.

Problem 11.4. (a) There exists a unique Vassiliev-Goussarov invariant $v_{2}: \Sigma \rightarrow \mathbb{R}$ of order at most 2 such that $v_{2}(O)=0$ for the trivial knot $O$ and $v_{2}(1212)=1$. (Here (1212) is the 'non-trivial' chord diagram with 2 chords, see [PS96, Figure 4.4], 3rd diagram of the first line.)

Hint. This follows from theorem 9.4, but try to deduce this from theorem 11.1.

$\left(b, b^{\prime}, c, d\right)$ Calculate $v_{2}$ for the (arbitrary oriented) right trefoil, left trefoil, figure eight knot and the $5_{1}$ knot.

Problem 11.5. (a) There exists a unique Vassiliev-Goussarov invariant $v_{3}: \Sigma \rightarrow \mathbb{R}$ of order at most 3 such that $v_{3}(O)=0$ for the trivial knot $O$ and for the left trefoil $O$, and $v_{3}(123123)=1$. (Here (123123) is the 'non-trivial most symmetric chord diagram with 3 chords', see [PS96, Figure 4.4], 5th diagram of the second line.)

$\left(b, b^{\prime}, c, d\right)$ Same as problem 11.4 for $v_{3}$.

Hints. See Problems 2, 3, 4ab, Results/Theorems 11, 13, 14 from [PS96, \$4].

Problem 11.6. (a) [PS96, Problem 4.4.b] There exists a unique Vassiliev-Goussarov invariant $v_{4}: \Sigma \rightarrow \mathbb{R}$ of order at most 4 such that

- $v_{4}(O)=0$ for the trivial knot $O$, for the left trefoil $O$, and for the right trefoil $O$,

- $v_{4}(12341234)=2, v_{4}(12341432)=3$ and $v_{4}(12341423)=5$.

$\left(b, b^{\prime}, c, d\right)$ Same as problem 11.4 for $v_{4}$.

\section{Appendix: some details}

1.1. ( $\mathrm{a}, \mathrm{b})$ 'Probably the best way of solving this problem is to make a model of the trefoil knot and the figure eight knot by using a shoelace and then move it around from one position to the other. Fig. 24 gives some hints concerning transformations of the trefoil and the figure eight knot.' [Pr95, §2] (Fig. 24, left, is prepared by D. Kroo.)

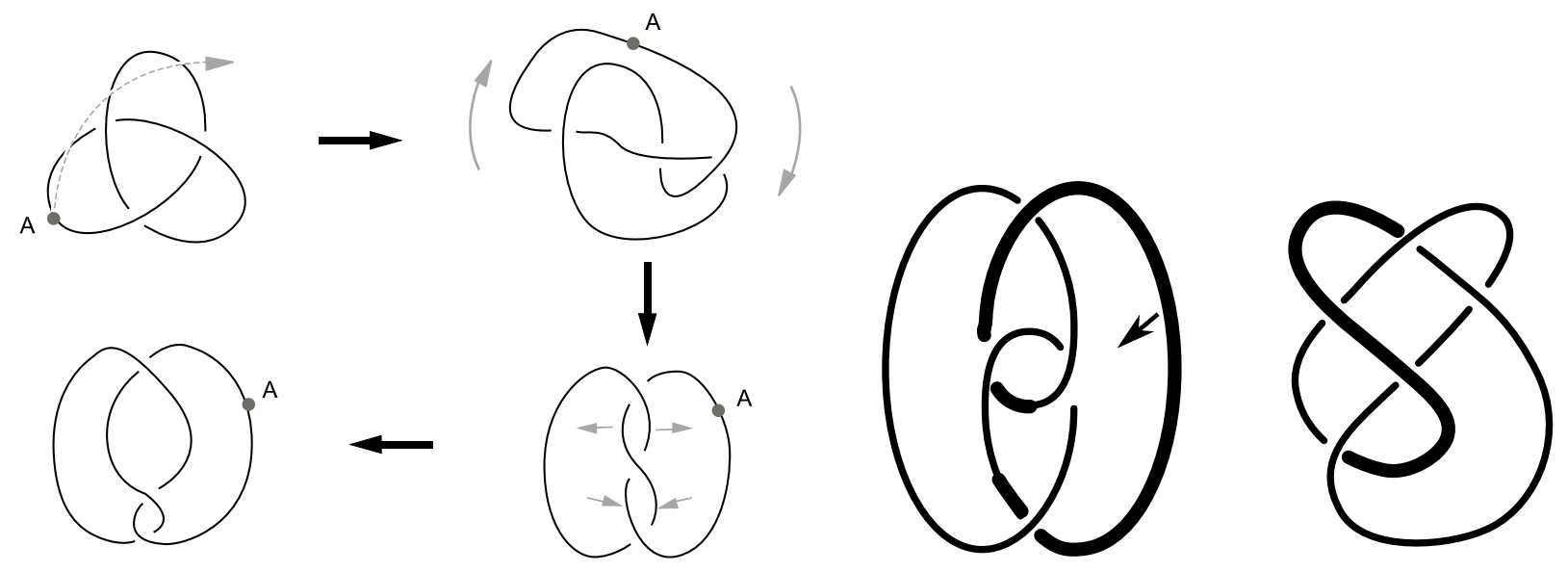

Figure 24: Isotopy the trefoil and of the figure eight knot

(e) Consider two knots with coinciding plane diagrams in a 'horizontal' plane $\pi$. For each point $X$ in the space let $p(X)$ be the line containing $X$, perpendicular to $\pi$. Let $h(X)$ be the height of $X$ relative to $\pi$, that is positive $(h(X)>0)$ if $X$ is in the upper half-space, and is negative $(h(X)<0)$ if $X$ is in the lower half-space. To each point $A$ of the first knot associate a point $A^{\prime}$ of the second knot by the following procedure. 
Case 1: The projection of the point $A$ on $\pi$ is not a crossing point on the plane diagram. In this case $p(A)$ intersects the first knot only at the point $A$. Since the plane diagrams coincide, the line $p(A)$ intersects the second knot also at a single point. Define $A^{\prime}$ to be this point.

Case 2: The projection of the point $A$ on $\pi$ is a crossing point of the plane diagram. In this case the line $p(A)$ intersects the first knot in an additional point $B$. Since the plane diagrams coincide, the line $p(A)$ intersects the second knot in two points $C$ and $D$, where we assume that $h(C)>h(D)$. If $h(A)>h(B)$, we define $A^{\prime}=C$, and in the opposite case $A^{\prime}=D$.

For each point $A$ of the first knot and each number $t \in[0,1]$ let $A(t)$ be the point on the line $p(A)$ with the height $h(A(t))=(1-t) h(A)+t h\left(A^{\prime}\right)$. By construction $A(0)=A, A(1)=A^{\prime}$ and the transformation of the first knot, which moves $A(0)$ in the direction of $A(1)$ with constant speed, so that at the time $t$ it occupies the position $A(t)$, is the required isotopy.

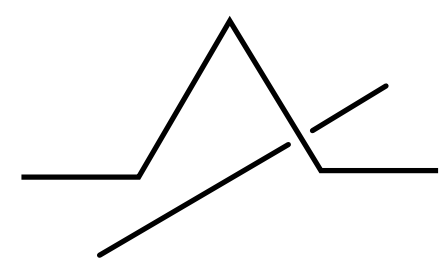

Figure 25: The bridge over some crossing point

1.3. See fig. 25, For each crossing point of the plane diagram, on the upper edge of the crossing, choose two points, close to the intersection and on the opposite sides of the intersection. Replace the line segment between the two chosen points by a 'bridge' rising above the plane diagram, which connects these two points. After replacing all crossing points by the corresponding bridges, we obtain the required knot.

1.4. (a) Use the results of problems 5.1,b, 9.1, a and lemmas 5.2.ab, 9.2.ab. Alternatively, use the results of problem 6.1, ab and lemma 6.2

(b) Take any of the connected sums of $n$ trefoil knots. By the results of problems 9.1, a and 9.3, a the Casson invariant of this knot is $n$. Hence by lemma 9.2, ab these knots for different values of $n$ are not isotopic.

2.2. (a) In order to distinguish the Hopf link from the other two use the result of problem 4.1 and lemma 4.2. In order to distinguish the Whitehead link from the trivial link use the result of problem 6.1 (or 10.3) and lemma 6.2 (or theorem 10.2).

(b) Use the result of problem 10.3 and theorem 10.2 .

3.2. Choose a knot projected to the given plane diagram in the same way as in assertion 1.3 . Suppose that all the 'bridges' lie in the upper half-space w.r.t. the projection plane. By the assumption there are points $X$ and $Y$ on the knot which divide the knot into two polygonal lines $p$ and $q$ such that

- $q$ lies in the projection plane and passes only through undercrossings;

- $p$ is projected to polygonal line $p^{\prime}$ which passes only through overcrossings.

Take a point $Z$ in the upper half-space, and a point $T$ in the lower half-space. Let us construct an isotopy between the given knot and the closed polygonal line $X Z Y T$, which is isotopic to the trivial knot. The isotopy consists of 3 steps, all of them keeping $X, Y$ fixed.

Step 1. An isotopy between $q$ and $X T Y$. Suppose that $q=A_{0} A_{1} \ldots A_{n}$, where $A_{0}=X$ and $A_{n}=Y$. Then the isotopy is given by

$$
A_{0} A_{1} \rightarrow A_{0} T A_{1}, \quad T A_{1} A_{2} \rightarrow T A_{2}, \quad T A_{2} A_{3} \rightarrow T A_{3}, \quad \ldots T A_{n-1} A_{n} \rightarrow T A_{n}
$$

Step 2. An isotopy between $p$ and $p^{\prime}$. Remove all the 'bridges' by elementary moves. Step 3. An isotopy between $p^{\prime}$ and $X Z Y$. This is done analogously to step 1. 
3.3. Follows by assertion 3.2 .

Another idea of the proof (cf. [PS96, Theorem 3.8]). Denote by $\pi$ the horizontal plane containing the plane diagram. For each point $X$ in the space, $p(X)$ and $h(X)$ are defined in the solution of the problem 1.1.c. Let $l$ be a line in the plane, which passes through a vertex $A_{0}$ of the plane diagram, while the whole diagram is contained in one of the two half-planes determined by $l$. Let $A_{0}, A_{1}, \ldots A_{n}$ be all vertices of the plane diagram, in the order of their appearance, while we move along the diagram in some direction. Choose points $B_{0}, \ldots, B_{n}$ so that $A_{i} \in p\left(B_{i}\right)$ for $i=1, \ldots, n$, and $h\left(B_{i}\right)<h\left(B_{j}\right)$ for $i<j$. Let $B_{n+1}$ be a point, whose projection on $\pi$ is close to $A_{0}$ and $h\left(B_{n+1}\right)>h\left(B_{n}\right)$. We claim that the knot $B_{0} \ldots B_{n} B_{n+1}$ is isotopic to the trivial knot. Indeed, by the choice of the line $l$, the projection of the knot onto any plane, perpendicular to the line $l$, is a closed polygonal line without self-intersections. It remains to modify crossing in the plane diagram so that they are in agreement with the projection of the constructed knot to the plane $\pi$.

4.1. Answer: 1 for the Hopf link and 0 for other links.

4.2. For moves I and III the number of crossing points where the first component passes above the second one does not change. For move II this number changes by 0 or \pm 2 .

4.3. (a) Take a plane diagram of a link. By the Parity lemma stated before assertion 4.3 the number of crossing points where the first component passes above the second one has the same parity as the number of crossing points where the second component passes above the first one. This is the required statement.

(b) An example is the third link in fig. 4. This link is not isotopic to the trivial link because they have distinct linking numbers, see $\$ 8$.

4.4. Existence. By lemma 4.2 the linking number modulo 2 is an isotopy invariant. The skein relation is easy to check.

Uniqueness. Suppose that $\mathrm{f}$ is another invariant aside from $\mathrm{lk}_{2}$ satisfying the assumptions. Then $\mathrm{f}-\mathrm{lk}_{2}$ is an isotopy invariant assuming zero value on the trivial link and invariant under crossing changes. The analogue of lemma 3.3 for links states that any plane diagram of a link can be obtained from the diagram of a link isotopic to the trivial link by some crossing changes. Hence $\mathrm{f}-\mathrm{lk}_{2}=0$.

5.1. (a) If $P$ is a point on the plane diagram as in assertion 3.2, then there are no $P$-skew pairs of crossings. Hence the $P$-Arf invariant is zero.

5.2. (a) Let $P_{1}$ and $P_{2}$ be two basepoints such that the segment $P_{1} P_{2}$ contains exactly one crossing point $X$.

Case 1: $P_{1} P_{2}$ passes through undercrossing. Then $X$ does not form either $P_{1}$-skew or $P_{2}$-skew pair with any other crossing. Hence $P_{1^{-}}$and $P_{2}$-Arf invariants of the diagram are equal.

Case 2: $P_{1} P_{2}$ passes through overcrossing. Then $X$ divides the diagram into two closed polygonal lines $q_{1}$ and $q_{2}$ such that $P_{1}$ lies on $q_{1}$ and $P_{2}$ lies on $q_{2}$. Denote by $n_{1}$ (respectively, $n_{2}$ ) the number of intersections of $q_{1}$ and $q_{2}$ for which $q_{1}$ passes above $q_{2}$ (respectively, $q_{2}$ passes above $q_{1}$ ). Denote by $N_{1}$ the number of $P_{1}$-skew pairs formed by $X$ and some intersection of $q_{1}$ and $q_{2}$. Denote by $\operatorname{arf}_{P_{1}} D$ the $P_{1}$-arf invariant of $D$. Use analogous notation with $P_{1}$ replaced by $P_{2}$. Then

$$
\operatorname{arf}_{P_{1}} D-\operatorname{arf}_{P_{2}} D=N_{1}-N_{2}=n_{1}-n_{2} \underset{\overline{2}}{\equiv} n_{1}+n_{2} \underset{2}{\equiv} 0
$$

where $D$ is the given plane diagram. Here

- the first equality holds because a pair of crossings is either $P_{1}$-skew or $P_{2}$-skew (but not both) if and only if the pair is formed by $X$ and some intersection of $q_{1}$ and $q_{2}$;

- the second equality holds because $N_{1}=n_{1}$ and $N_{2}=n_{2}$; indeed, an intersection of $q_{1}$ and $q_{2}$ forms a $P_{1}$-skew (respectively, $P_{2}$-skew) pair with $X$ if and only if at this intersection $q_{1}$ passes above (respectively, below) $q_{2}$; 
- $\bar{\equiv}$ are congruences modulo 2;

- the last congruence follows by the Parity lemma for $q_{1}$ and $q_{2}$.

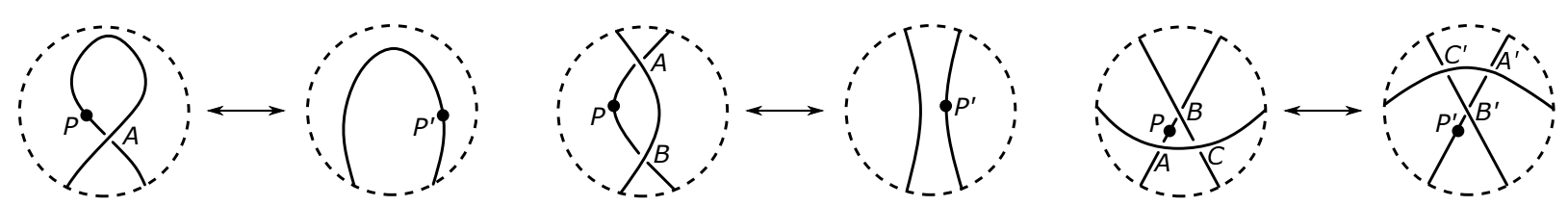

Figure 26: Arf-invariant does not change under Reidemeister moves

(b) Type I move. Take basepoints before and after the move as in fig. 26 (left). Check that the crossing $A$ does not form a $P$-skew pair with any other crossing.

Type II move. Take basepoints before and after the move as in fig. 26 (middle). Check that neither of the crossings $A$ and $B$ forms a $P$-skew pair with any other crossing.

Type III move. Take basepoints before and after the move as in fig. 26 (right). Check that neither of the crossings $A, B$ forms a $P$-skew pair with any other crossing and that neither of the crossings $A^{\prime}, B^{\prime}$ forms a $P^{\prime}$-skew pair with any other crossing. Then check that a crossing $X$ distinct from $A, B, C$ forms a $P$-skew pair with $C$ if and only if $X$ forms a $P^{\prime}$-skew pair with $C^{\prime}$.

5.3. Take any connected sum $K$ of the two trefoil knots. By assertion 7.4. $\mathrm{d}$ arf $K=0$. By the result of problem 9.1.b and assertion 9.3. a $c_{2}(K) \neq 0$. Hence $K$ is not isotopic to the trivial knot.

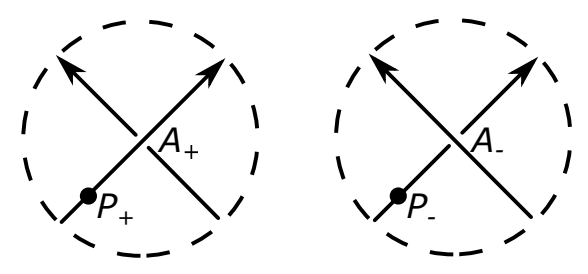

Figure 27: To the proof of skein relation for Arf invariant

5.4. Existence. By lemma 5.2, the arf invariant is an isotopy invariant. Here are hints for checking the skein relation. Take basepoints $P_{+}, P_{-}$as in fig. 27. Check that the crossing $A_{-}$does not form a $P_{-}$-skew pair with any other crossing in $K_{-}$. Then check that the number of crossings which form a $P_{+}$-skew pair with $A_{+}$in $K_{+}$equals $\mathrm{lk}_{2} K_{0}$ modulo 2 .

Uniqueness. The proof is analogous to the proof of theorem 4.4. Use lemma 3.3 itself instead of its analogue for links.
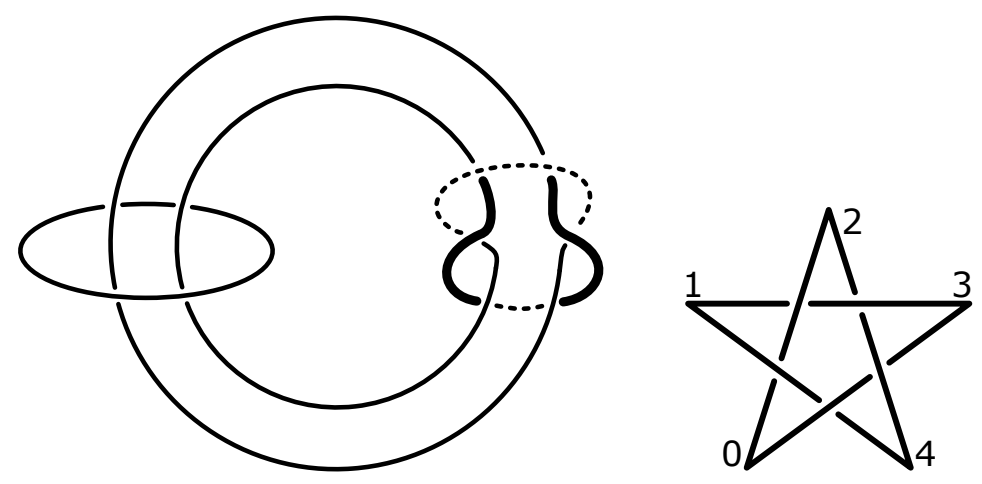

Figure 28: A 3-coloring of a link and a 5-coloring of the $5_{1}$ knot

6.1. Answers: b,e,h - 3-colorable, a,c,d,f,g,i - not 3-colorable. For a proper coloring of a diagram of trefoil knot see [Pr95, p. 30, figure 4.3]. For a proper coloring of the last diagram from 
fig. 4 see fig. 28 left. (This diagram was erroneously stated to be not 3-colorable in [Pr95, §4]. This minor mistake was found by L.M. Bannöhr, S. Zotova and L. Kravtsova.)

6.3. (a) Most part of (a) follows by lemma 6.2 and results of problems 6.1],d-h (see [Pr95, p. 30]). The last diagram from fig. 4 is distinguished from the trivial link by the number of proper colorings of a plane diagram. Prove that this number is preserved under the Reidemeister moves.

(b) A plane diagram is 5-colorable if there exists a coloring of its strands in five colors $0,1,2,3,4$ so that at least two colors are used, and at each crossing if the upper strand has color $a$ and two lower strands have colors $b$ and $c$, then $2 a \equiv b+c(\bmod 5)$. Similarly to lemma 6.2 the 5colorability of a plane diagram is preserved under Redemeister moves. The $51_{1}$ knot is 5 -colorable, see fig. 28, right. The trivial knot is not. Hence they are not isotopic.

7.1. (b) First solution. An oriented polygonal line is called positive if the bounded part of the plane is always on the left side of each of its oriented segments (see the Jordan theorem in remark 3.1). Prove that the positivity of an oriented polygonal line is preserved by elementary moves.

Hint to the second solution. The positivity can be equivalently defined as follows. We say that an oriented polygonal line $A_{1} \ldots A_{n}$ is positive if for each of its inner (interior) points $O$ the sum of oriented angles $\angle A_{1} O A_{2}+\angle A_{2} O A_{3}+\ldots+\angle A_{n-1} O A_{n}+\angle A_{n} O A_{1}$ is always positive (i.e. the winding number of the oriented polygonal line around any interior point is positive).

7.2. Each of the three indicated oriented knots is transformed into the oriented knot with the opposite orientation by the rotation through the angle $\pi$ around the 'vertical' axis passing through the 'upper' point of the knot (see the leftmost diagram in fig. 1, the first and the second row for the trefoil and the figure eight knot, respectively). This rotation is included into a continuous family of rotations through the angle $\pi t, t \in[0,1]$, with respect to the same line. This is the required isotopy.

7.7. (d) Check that all crossings of different components in $K \# L$ are obtained from such crossings in $K$ and in $L$.

8.1. Answers: $\pm 1 ; 0$.

8.3. (a) The proof is analogous to assertion 4.3. a. Take a plane diagram of a link. By the Triviality lemma (stated before assertion 8.3) the sum of signs of crossing points where the first component passes above the second one has opposite sign to the sum of signs of crossing points where the second component passes above the first one. Switching the components negates the sign of every crossing point. This completes the proof.

(b) Reversing the orientation of either of the components negates the sign of every crossing point.

(c) Take the connected sum of 5 Hopf links oriented so that their linking numbers equal to -1 .

(d) The proof is analogous to assertion 7.4, d. The signed set of crossing points of plane diagram of $K \# L$ is the union of the signed sets of crossing points of plane diagrams of links $K$ and $L$.

(e) An example is the Whitehead link. The Whitehead link is not isotopic to the trivial link by theorem 2.2. a.

9.1. (a) Answers: 0, 1 and -1 .

The trivial knot has no crossings, and so no skew pairs of crossings. Therefore the Casson invariant of this knot is 0 .

All three crossings of the trefoil knot have the same sign. Since the trefoil knot has exactly one linked pair of crossings (regardless the choice of the base-point), we obtain that the Casson invariant of this knot is 1 .

(b) Take any connected sum of five figure eight knots. By (a) and assertion 9.3, a below the Casson invariant of this knot is -5 .

9.2, 9.3. a, 9.4, The proofs are analogous to lemma 5.2, assertion 5.3 and theorem 5.4, respectively. Take care of the signs of intersection points. For lemma 9.2. a use the Triviality 
lemma stated before assertion 8.3 .

9.3. (b) Take any connected sum of the trefoil knot and the figure eight knot. By (a) and the answer to problem 9.1. a the Casson invariant of this knot is 0. However, by the answers to problems 10.3, d,e and assertion 10.5. c the Conway polynomial of this knot is $\left(1+t^{2}\right)\left(1-t^{2}\right) \neq 1$. Hence this knot is not isotopic to the trivial knot.

10.1. (b) Answer: 0.

Remark. The invariant arf $=c_{2} \bmod 2$ for links may depend on the orientation on the components (for $c_{3} \bmod 2$ see [CDM, 2.3.4]).

Let $D$ be a plane diagram of a link. Denote by $\operatorname{cr} D$ the number of crossings in $D$. Denote by $\operatorname{ch} D$ the minimal number of crossing changes required to obtain from $D$ a diagram of a link which is isotopic to the trivial one (such sequence of crossing changes exists by the analogue of lemma 3.3 for links).

10.2. The uniqueness is analogous to theorems 8.4,9.4, solve first problem 10.3 ,

Deduction of the stronger version (for non-ordered links) from the weaker version (for ordered links). It suffices to show that all invariants $c_{n}$ defined for ordered links are preserved under changes of the order of the components.

Let $D$ be a plane diagram of a link with two or more components and let $D^{\prime}$ be a plane diagram obtained from $D$ by a change of the components' order. The proof is by induction on $\mathrm{cr} D$. If $\operatorname{cr} D=0$, then $D$ is a diagram of a link which is isotopic to the trivial one and by the answer to problem 10.3. b we have $C(D)=0$ for any ordering of the components. Suppose that $\operatorname{cr} D>0$; then continue the proof by induction on $\operatorname{ch} D$. If $\operatorname{ch} D=0$, then $D$ is a diagram of a link which is isotopic to the trivial one; this case is considered above. Suppose that $\operatorname{ch} D>0$. Let $D_{*}$ be a link obtained from $D$ by a crossing change and such that $\operatorname{ch} D_{*}<\operatorname{ch} D$. Denote by $D_{*}^{\prime}$ is a link obtained from $D^{\prime}$ by the change of the same crossing. Then

$$
\pm\left(C(D)-C\left(D_{*}\right)\right)=C\left(D_{0}\right) \quad \text { and } \quad \pm\left(C\left(D^{\prime}\right)-C\left(D_{*}^{\prime}\right)\right)=C\left(D_{0}^{\prime}\right)
$$

where $D_{0}$ is a diagram of a link $K_{0}$ (with some ordering of the components) from fig. 21 for $D$, $D_{*}$ being $D_{+}, D_{-}$in some order, and $D_{0}^{\prime}$ is the same for $D^{\prime}, D_{*}^{\prime}$. Note that the diagrams $D_{*}$ and $D_{*}^{\prime}$ coincide up to the order of the components. The same is true for the diagrams $D_{0}$ and $D_{0}^{\prime}$. Since $\operatorname{ch} D_{*}<\operatorname{ch} D$ and $\operatorname{cr} D_{0}<\operatorname{cr} D$, by the inductive hypotheses we have $C\left(D_{*}\right)=C\left(D_{*}^{\prime}\right)$ and $C\left(D_{0}\right)=C\left(D_{0}^{\prime}\right)$. Then $C(D)=C\left(D^{\prime}\right)$.

10.3. Answers: (a, b) 0; (c) $\pm t$; (d) $1+t^{2}$; (e) $1-t^{2}$; (f) $\pm t^{3}$; (g) $\pm t^{4}$; (h) $1+3 t^{2}+t^{4}$.

Remark. The signs in the answers to (c), (f), (g) depend on the orientation on the components.

Hint. For examples of such calculations for (a), (c), and (d) see [CDM, 2.3.2].

10.4. Let $D$ be a plane diagram of the given link $K$.

(a) For any diagram $D_{*}$ obtained from $D$ by a crossing change we have $c_{0}(D)-c_{0}\left(D_{*}\right)=0$, i. e. $c_{0}$ does not change under crossing changes. By the analogue of lemma 3.3 for links the diagram $D$ can be obtained by crossing changes from a diagram of a link isotopic to the trivial one. The assertion follows from the definition of $c_{0}$ on the trivial knot and the answer to problem 10.3. b.

$(b, c)$ The first parts are particular cases of $(d)$. The second parts follow from the definition of $c_{1}, c_{2}$ and theorems $8.4,9.4$.

(d) The proof is by induction on cr $D$. If cr $D=0$, then $K$ is isotopic to the trivial link. If $K$ is a knot, then $C(D)=1$. Otherwise $C(D)=0$ by assertion 10.3. b. Suppose that $\mathrm{cr} D>0$; then continue the proof by induction on $\operatorname{ch} D$. If $\operatorname{ch} D=0$, then $K$ is isotopic to the trivial link; this case is considered above. Suppose that $\operatorname{ch} D>0$. Let $D_{*}$ be a link obtained from $D$ by a crossing change and such that $\operatorname{ch} D_{*}<\operatorname{ch} D$. Then $\pm\left(c_{j}(D)-c_{j}\left(D_{*}\right)\right)=c_{j-1}\left(D_{0}\right)$, where $D_{0}$ is the diagram from fig. 21 corresponding to $D, D_{*}$ being $D_{+}, D_{-}$in some order. Note that the link $D_{*}$ consists of $k$ components and the link $D_{0}$ consists of $k^{\prime}=k \pm 1$ components. Therefore if $j \leq k-2$, then 
$j-1 \leq k^{\prime}$ and if $j-k$ is even, then $(j-1)-k^{\prime}$ is even. Since $\operatorname{ch} D_{*}<\operatorname{ch} D$ and $\operatorname{cr} D_{0}<\operatorname{cr} D$, by the inductive hypothesis we have $c_{j}\left(D_{*}\right)=c_{j-1}\left(D_{0}\right)=0$. Then $c_{j}(D)=0$.

(e) Prove analogously to $(\mathrm{d})$ that $c_{j}(D)=0$ for any plane diagram $D$ and $j>\operatorname{cr} D$.

10.5. (a) The proof is analogous to assertion 10.4. d.

(c) Let $D$ and $E$ be plane diagrams of $K$ and $L$. Analogously to assertion 10.4.d prove that $C(D \# E)=C(D) C(E)$ by induction on $\operatorname{cr} D$ for fixed $E$.
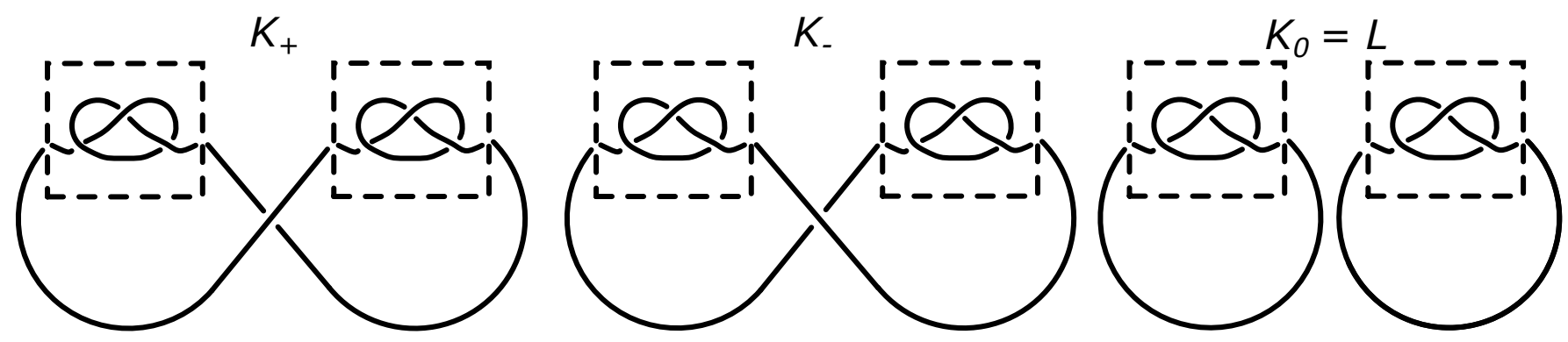

Figure 29: Proof that $C$ (split link $)=0$

10.6. (a) Follows from answers to problems 10.3, c,f,g and (b,c).

(c) If $L$ is a split link, then there exist links $K_{+}, K_{-}, K_{0}$ such that

- their plane diagrams differ like in fig. 21.

- the links $K_{+}$and $K_{-}$are isotopic;

- the link $K_{0}$ is isotopic to $L$.

We have $C(L)=C\left(K_{0}\right)=\frac{1}{t}\left(C\left(K_{+}\right)-C\left(K_{-}\right)\right)=0$, see fig. 29.

\section{References}

[Al28] J. W. Alexander. Topological invariants of knots and links, Trans. Amer. Math. Soc., $30: 2$ (1928), 275-306.

[As] A. Asanau. A simple proof that connected sum of ordered oriented links is not welldefined, preprint.

[CDM] * S. Chmutov, S. Duzhin, J. Mostovoy. Introduction to Vassiliev knot invariants, Cambridge Univ. Press, 2012. http://www.pdmi.ras.ru/ duzhin/papers/cdbook.

[CG83] J. H. Conway and C. M. A. Gordon, Knots and links in spatial graphs, J. Graph Theory 7 (1983), 445-453.

[CSK] * https://en.wikipedia.org/wiki/Connected_sum\#Connected_sum_of_knots

[EEF] * Proposed by D. Eliseev, A. Enne, M. Fedorov, A. Glebov, N. Khoroshavkina, E. Morozov, A. Skopenkov, R. Živaljević. A user's guide to knot and link theory, https://www .turgor.ru/lktg/2019.

[Ga20] T. Garaev. An elementary proof of the existence of the Conway polynomial (in Russian), https://www.mccme.ru/circles/oim/mmks/works2019/garaev4.pdf ; an update is submitted to arxiv in November 2020.

[HC19] * C. Herbert Clemens. Two-Dimensional Geometries. A Problem-Solving Approach, AMS, 2019.

[Ka06] * L.H. Kauffman. Formal Knot Theory, Dover Publications, 2006. 
[Ka06'] L.H. Kauffman. Remarks on Formal Knot Theory, arXiv:math/0605622 (note that the numbers and names of sections in table of contents in p. 1 are incorrect).

[Ka87] * L.H. Kauffman. On knots. Annals of Mathematics Studies. 115. Princeton University Press. 1987.

[Ko19] E. Kogan. Linking of three triangles in 3-space, arXiv:1908.03865.

[Ma18] * V. Manturov. Knot Theory. CRC press. 2018.

[Pr95] * V. V. Prasolov. Intuitive topology. Amer. Math. Soc., Providence, R.I., 1995.

[Pr98] * J. H. Przytycki. 3-coloring and other elementary invariants of knots, Banach Center Publications, 42 Knot Theory, Warsaw, 1998, 275-295, arXiv:math.GT/0608172.

[PS96] * V. V. Prasolov, A. B. Sossinsky Knots, Links, Braids, and 3-manifolds. Amer. Math. Soc. Publ., Providence, R.I., 1996.

[Sk] * A. Skopenkov. Algebraic Topology From Algorithmic Viewpoint, draft of a book, mostly in Russian, http://www.mccme.ru/circles/oim/algor.pdf.

[Sk14] * A. Skopenkov. Realizability of hypergraphs and Ramsey link theory, arxiv:1402.0658.

[Sk15] A. Skopenkov. Classification of knotted tori, Proc. A of the Royal Society of Edinburgh, 150:2 (2020), 549-567. Full version: arXiv:1502.04470.

[Sk16c] * A. Skopenkov, Embeddings in Euclidean space: an introduction to their classification, to appear in Boll. Man. Atl. http://www.map.mpimbonn.mpg.de/Embeddings_in_Euclidean_space:_an_introduction_to_their_classification

[Sk16i] * A. Skopenkov, Isotopy, submitted to Boll. Man. Atl. http://www.map.mpim-bonn.mpg.de/Isotopy.

[Sk18] * A. Skopenkov. Invariants of graph drawings in the plane. Arnold Math. J., 6 (2020) 21-55; full version: arXiv:1805.10237.

[Sk20m] * A. Skopenkov. Mathematics Through Problems: from olympiades and math circles to a profession. Part I. Algebra. AMS, Providence, to appear. Preliminary version: https://www.mccme.ru/circles/oim/algebra_eng.pdf

[Sk20] * A. Skopenkov. Algebraic Topology From Geometric Viewpoint (in Russian), MCCME, Moscow, 2020 (2nd edition). Electronic version: http://www.mccme.ru/circles/oim/home/combtop13.htm\#photo

[So89] * A. Sossinsky. Knots, links and their polynomials (in Russian). Kvant, 1989, N4, http://kvant.mccme.ru/1989/04/uzly_zacepleniya_i_ih_polinomy.htm.

Books, surveys and expository papers in this list are marked by the stars. 


\title{
Основы теории узлов и зацеплений для пользователя*
}

\author{
A. Скопенков ${ }^{\dagger}$
}

\begin{abstract}
Аннотация
Это методическая статья. Мы определяем простые инварианты узлов и зацеплений (коэффициент зацепления, инварианты Арфа-Кэссона и многочлен АлександераКонвея) для применения к интересным результатам, формулировки которых доступны неспециалисту. Простейшие инварианты естетственно появляются при попытках распутать узел или зацепление. Затем мы представляем рекурсивные скейн-соотношения для простейших инвариантов, которые позволяют ввести более сложные инварианты. Мы формулируем теорему Васильева-Концевича в виде, удобном для вычислления самих инвариантов, а не только размерности пространства инвариантов. Предварительных знаний не требуется; мы даем строгие определения основных объектов на языке, не препятствуующем их интуитивному пониманию.
\end{abstract}

\section{Содержание}

1 Основные определения и результаты об узлах 2

2 Основные определения и результаты о зацеплениях

3 Основные инструменты 6

4 Гауссов коэффициент зацепления по модулю 2

5 Арф-инвариант 9

6 Приложение: правильные раскраски 10

7 Ориентированные узлы и зацепления; связные суммы 11

8 Гауссов коэффициент зацепления 14

9 Инвариант Кэссона 16

10 Полином Александера-Конвея 16

11 Инварианты Васильева-Гусарова 18

12 Некоторыегдоказательства, указанияг и решения 20

*Благодарю А. Еннэ за подготовку рисунков и работу над [EEF] после Летней конференции, Е. Морозова за перевод обновленной мной версии на русский язык и А. Глебова, Д. Елисеева, А. Еннэ, Р. Живалевича, Е. Морозова, А. Рябичева, А. Сосинского, М. Федорова, Н. Хорошавкину, С. Чмутова за полезные обсуждения и нашу работу над $\mathrm{EEF}$. Этот текст основан на лекциях автора в Независимом Московском Университете (включая Math in Moscow Program) и в Московском Физико-Техническом Институте, а также на [EEF].

${ }^{\dagger}$ https://users.mccme.ru/skopenko, Московский Физико-Технический Институт, Независимый Московский Университет. Частично поддержан грантом РФФИ No. 19-01-00169 и грантом фонда Саймонса-НМУ. 


\section{О стиле этого текста}

Как правило, я привожу формулировку красивого или важного утверждения перед последовательностью определений и результатов, составляющих его доказательство. В таких случаях для доказательства утверждения требуется часть дальнейшего материала. Об этом указано после формулировок (но я не хочу лишать Вас удовольствия найти момент, когда вы наконец-то сможете доказать такое утверждение). Некоторые теоремы приведены без доказательств, тогда даются ссылки вместо указаний.

Утверждения в этом тексте - простые элементы теории (для читателя, частично знакомого с материалом, они являются краткими напоминаниями). С той же целью приведено небольшое количество задач. Указания, решения и доказательства к утверждениям, задачам, теоремам и леммам приведены в $\$ 12$. Однако рекомендую читателю подумать над ними самостоятельно. Изучение путем решения задач не только характерно для серьезного изучения математики [HC19, §1.1], [ZSS, §1.2], но и продолжает древнюю культурную традицию1]

Замечания формально не используются в дальнейшем.

\section{1 Основные определения и результаты об узлах}

Начнем с неформального описания основных понятий (строгие определения даны после замечания (1.2).Узел можно представить себе как тонкую эластичную веревку, концы которой склеены - см. рис. 1, Как и на этом рисунке, узлы обычно изображаются с помощью их «удобной» проекции на плоскость, которая называется диаграммой узла. Представьте, что вы раскладываете веревку на столе, тщательно записывая как она пересекает себя (т.е. какая часть веревки лежит сверху). Необходимо помнить, что проекции одного и того же узла на разные плоскости могут выглядеть по-разному.

Тривиальный узел - это контур (граница) треугольника.
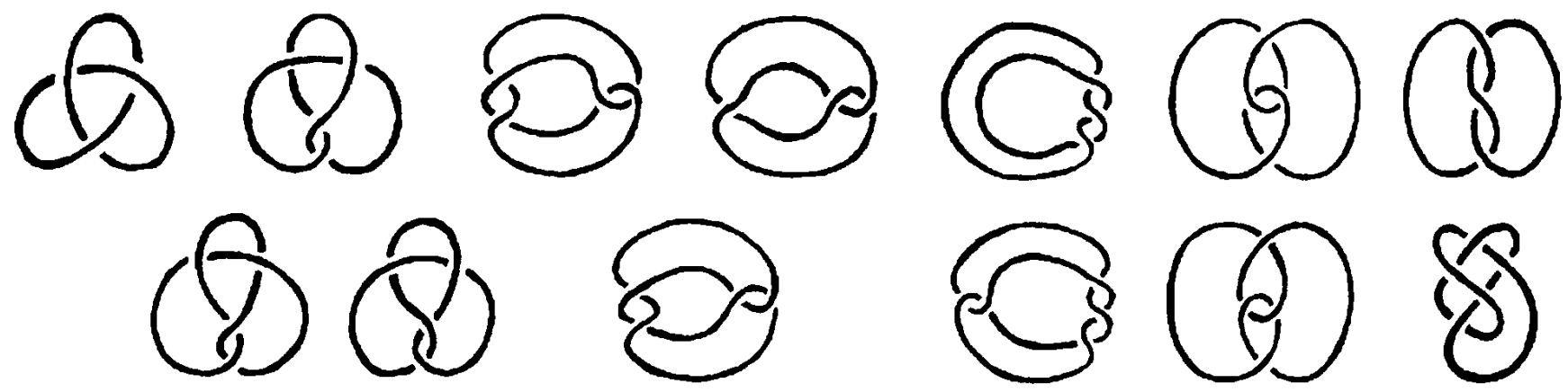

Рис. 1: Узлы, изотопные трилистнику (верхний ряд) и восьмерке (нижний ряд)

Под изотопией узла понимается его непрерывная деформация в пространстве как тонкой эластичной нити; любые самопересечения нити во время деформации запрещены. Два узла называются изотопными, если один из них можно преобразовать в другой с помощью изотопии.

Утверждение 1.1. (а) Все узль, представленные в верхнем ряду на рис. 1, изотопны друг другу. (Для одной пары из этих узлов представъте изотопию с помощъю движений Рейдемейстера, показанных на рис. 9.)

\footnotetext{
${ }^{1}$ Например, послушники дзенских монастырей обучаются, размышляя над загадками, данными им наставниками. Впрочем, эти загадки являются скорее наводящими на размышления парадоксами, а не задачами. См. подробнее $[\mathrm{Su}]$.
} 
(b) То же верно для узлов в нижнем ряду на рис. 1 .

(с) Все узль с одинаковыми диаграммами изотопны.

Замечание 1.2 (почему строгое определение изотопии необходимо?). На рис. 2 показана изотопия между трилистником и тривиальным узлом.

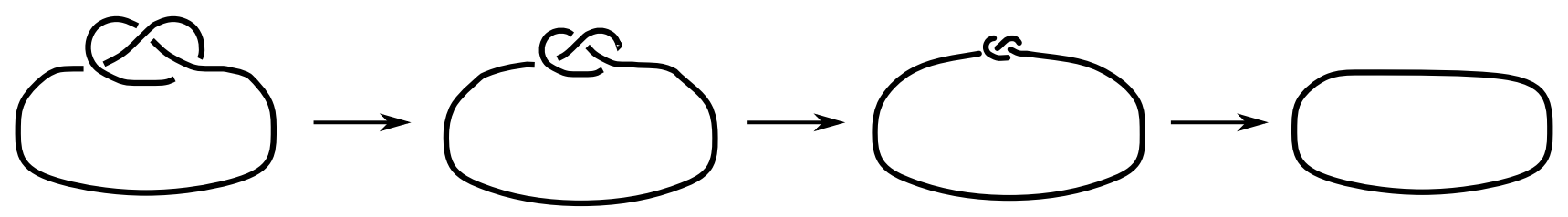

Рис. 2: Необъемлемая изотопия между трилистником и тривиальным узлом

Действительно ли это изотопия? Это так называемая «кусочно-линейная необъемлемая изотопия», которая отличается от «кусочно-линейной объемлемой изотопии», определенной и используемой далее. (Первое понятие лучше отражает идею непрерывной деформачии без самопересечений, но малодоступно для старшеклассников, ср. [Sk16i].) На самом деле, любые два узла кусочно-линейно необвемлемо изотопнь!

Обычная проблема при работе с интуитивными определениями не в том, что их трудно сделать строгими, а в том, что это можно сделать разными неэквивалентными способами.

Узел - это пространственная замкнутая несамопересекающаяся ломаная.2

Плоская диаграмма узла - это его проекция общего положения 3 на плоскость4, вместе с информацией, какая часть узла «проходит под» (проход), а какая - «проходит над» (переход) в каждом конкретном перекрестке.

Утверждение 1.3. Для любой диаграммы узла существует узел, проецирующийся на эту диаграмму. (Такой узел не обязательно единственный; см. впрочем утверждение 1.1. с.)

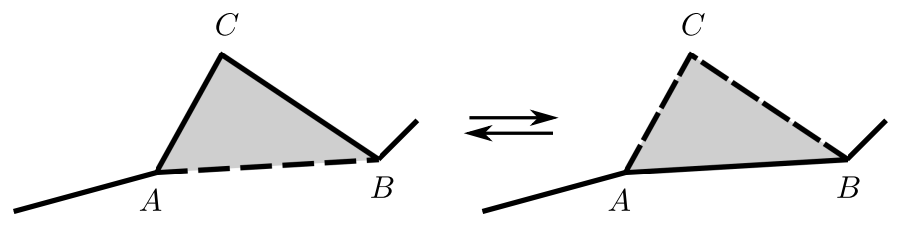

Рис. 3: Элементарное движение

Предположим, что стороны $A C$ и $C B$ треугольника $A B C$ - ребра некоторого узла. Кроме того, предположим, что узел и часть плоскости, ограниченная треугольником $A B C$, ни в каких других точках не пересекаются. Элементарное движение $A C B \rightarrow A B-$ это замена двух ребер $A C$ и $C B$ ребром $A B$, либо обратная операция $A B \rightarrow A C B$ (рис. 3) 5 Два узла $K, L$ называются (кусочно-линейно объемлемо) изотопными, если существует последовательность узлов $K_{1}, \ldots, K_{n}$ такая, что $K_{1}=K, K_{n}=L$, и каждый узел последовательности $K_{j+1}$ получен из предыдущего узла $K_{j}$ элементарным движением.

\footnotetext{
${ }^{2}$ Его не следует путать с ориентированным узлом, определенным далее в $\$ 7$.

${ }^{3}$ Ломаная на плоскости называется ломаной общего положения, если существует ломаная $L$ с тем же объединением ребер такая, что никакие 3 вершины ломаной $L$ не лежат на одной прямой, и никакие три отрезка, соединяющие некоторые вершины ломаной $L$, не имеют общей внутренней точки.

${ }^{4}$ Терминология университетской математики - «образ общего положения при проекции на плоскость».

${ }^{5}$ Если треугольник $A B C$ вырожденный, то элементарное движение является либо разбиением ребра, либо обратной операцией.
} 
Теорема 1.4. (а) Следующие узль попарно не изотопны: тривиальный узел, трилистник, восъмерка.

(b) Существует бесконечное множество попарно не изотопных узлов.

Эта теорема доказывается с помощью инвариантов Арфа и Кэссона, см. \$5 и \$9, ср. \$6.

Зеркалъный образ узла $K$ - это узел, плоская диаграмма которого получается изменением всех перекрестков (рис. 8) диаграммы узла $K$. Из утверждения 1.1.b следует, что восьмерка изотопна своему зеркальному образу.

Теорема 1.5. Трилистник не изотопен своему зеркальному образу.

Теорема 1.5 доказывается с помощью полинома Джонса [PS96, §3], [CDM, §2.4]. Доказательство выходит за рамки данного текста.

Теорема 1.6. Если никакие 4 из 7 точек пространства не лежсат в одной плоскости, то существует замкнутая ломаная, составленная из некоторых отрезков, соединяющих эти точки, не изотопная контуру треугольника.

Эта теорема доказывается с помощью Арф-инварианта, см. \$5. Детали выходят за рамки данного текста, см. [CG83, теорема 2].

\section{2 Основные определения и результаты о зацеплениях}

Зацепление - это набор попарно непересекающихся узлов, которые называются компонентами зацепления. Упорядоченные наборы называются упорядоченными или раскрашенными зацеплениями, в то время как неупорядоченные наборы называются неупорядоченными или нераскрашенными зацеплениями. В этом тексте под словом «зацепление» понимается «упорядоченное зацепление».

Тривиальное зацепление (с любым числом компонент) - это зацепление, состоящее из треугольников, лежащих в параллельных плоскостях.

Плоские диаграммы и изотопии для зацеплений определяются так же, как и для узлов.

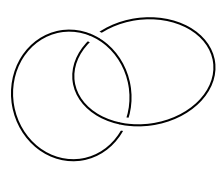

(a)

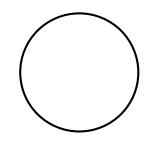

(b)

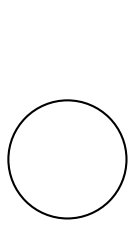

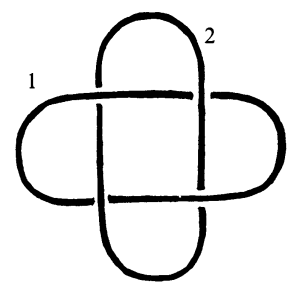
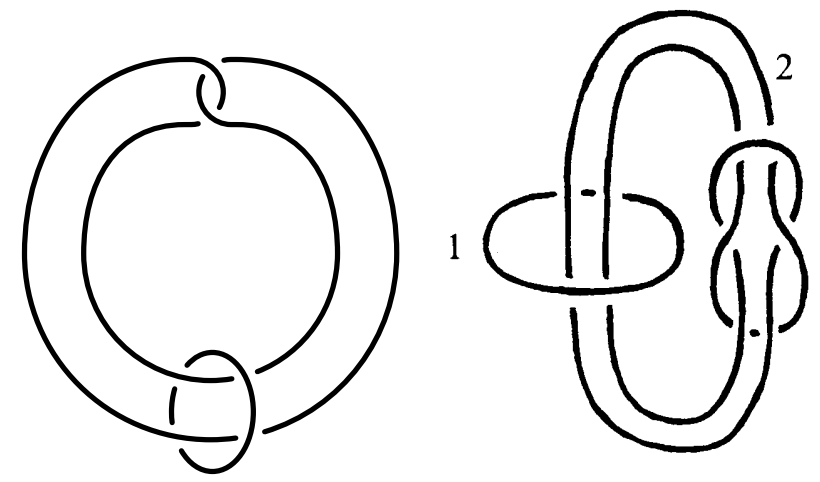

Рис. 4: Зацепление Хопфа, тривиальное зацепление и еще три зацепления 


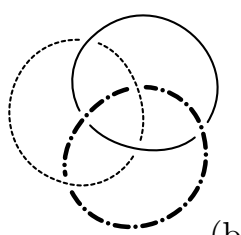

(b)

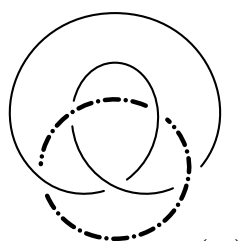

(w)

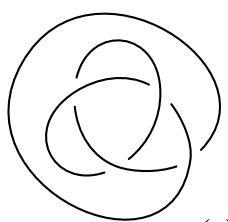

(t)

Рис. 5: Кольца Борромео, зацепление Уайтхеда и трилистник

Утверждение 2.1. (а) Зацепление Хопфа изотопно зацеплению, полученному из него перестановкой компонент.

(b) Зачепление Хопфа изотопно некоторому зацеплению, компоненты которого симметричны относительно некоторой прямой.

(c) Защепление на рис. 4 внизу слева изотопно защеплению Уайтхеда на рис. 5.

(d,e) То же, что и в пn. $(a, b)$ для зацепления Уайтхеда.

(f) Колъца Борромео изотопны защеплению, компоненты которого переставляются по циклу при повороте на угол $2 \pi / 3$ относительно некоторой прямой.

Доказательство. (а) Это следует из п. (b) (или может быть доказано независимо).

(d) Это следует из п. (е) (или может быть доказано независимо).
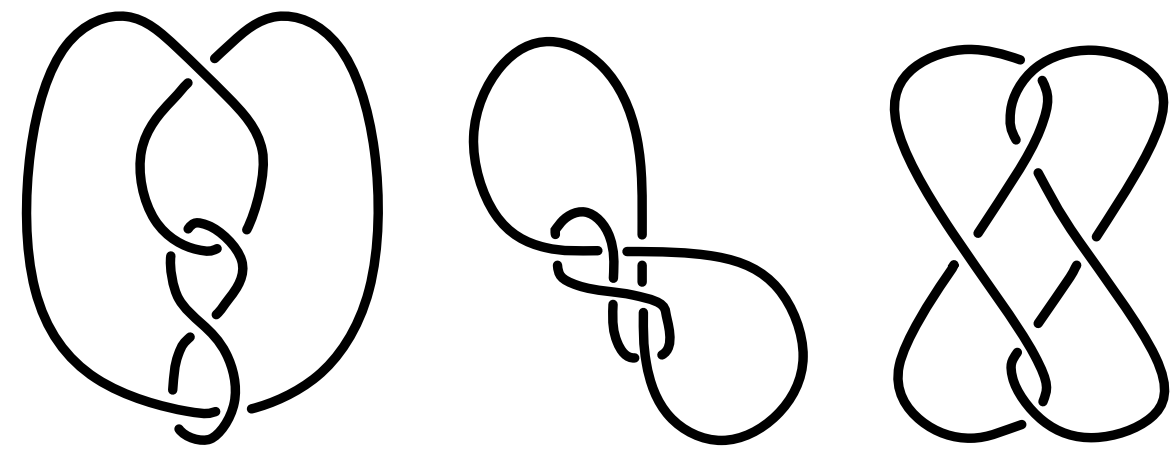

Рис. 6: Изотопия зацепления Уайтхеда

(е) См. рис. 6.

(f) Рассмотрим цветные четырехугольники на рис. 7 слева. Искомая прямая является биссектрисой любого октанта, образованного четырехугольниками.

Существует также следующая изящная криволинейная конструкция. Возьмем три эллипса, заданные системами уравнений

$$
\left\{\begin{array}{c}
x=0 \\
y^{2}+2 z^{2}=1
\end{array}, \quad\left\{\begin{array} { c } 
{ y = 0 } \\
{ z ^ { 2 } + 2 x ^ { 2 } = 1 }
\end{array} \quad \text { и } \quad \left\{\begin{array}{c}
z=0 \\
x^{2}+2 y^{2}=1 .
\end{array}\right.\right.\right.
$$

(См. рис. 7 справа.) Искомая прямая задается уравнением $x=y=z$.

Теорема 2.2. (а) Следующие защепления попарно не изотопны: зацепление Хопфа, тривиальное защепление, зачепление Уайтхеда.

(b) Кольца Борромео не изотопны тривиальному зацеплению.

Эта теорема доказывается с помощью коэфбищиента защепления по модулю 2, придумайте его самостоятельно или см. \$4, и полиномов Александера-Конвея, см. \$10. Также можно использовать «тройной коэффициент зацепления» (инвариант Масси-Милнора) и «высший коэффициент зацепления» (инвариант Сато-Левина) [Sk, §4.4-§4.6]. 

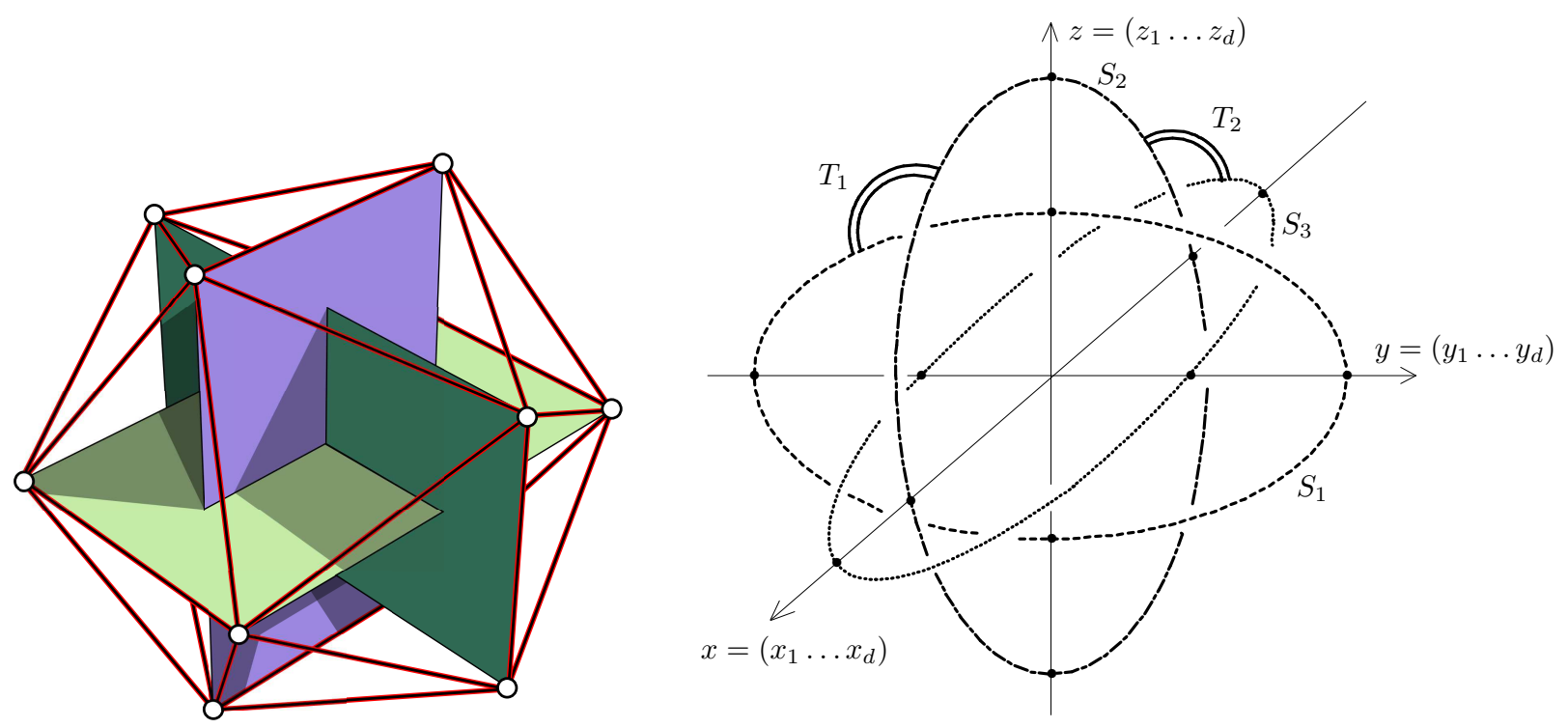

Рис. 7: Кольца Борромео

Теорема 2.3. Если никакие 4 из 6 точек пространства не лежат в одной плоскости, то существует пара зацепленных треугольников с вершинами в этих 6 точках. (Это означает, что внутренность первого треугольника пересекает контур второго треугольника ровно в одной точке.)

Эта теорема доказывается с помощью коэфбициента зацепления по модулю 2, см. \$4. Детали выходят за рамки данного текста, см. [CG83, теорема 1] и простое изложение в [Sk14, теорема 1.1].

\section{3 Основные инструменты}

Замечание 3.1 (некоторые строгие рассуждения). В следующем абзаце мы доказываем, что если узел лежит в плоскости, то он изотопен тривиальному узлу.

Обозначим узел, лежащий в плоскости, через $M_{1} M_{2} \ldots M_{n}$. Возвмем точку $Z$ вне этой плоскости. Тогда $M_{1} M_{2} \ldots M_{n}$ преобразуется в тривиальный узел $M_{1} Z M_{n}$ следующей последовательностью элементарных движений:

$$
M_{1} M_{2} \rightarrow M_{1} Z M_{2}, \quad Z M_{2} M_{3} \rightarrow Z M_{3}, \quad Z M_{3} M_{4} \rightarrow Z M_{4}, \quad \ldots, \quad Z M_{n-1} M_{n} \rightarrow Z M_{n} .
$$

Следуюший результат показывает, что промежуточные узль изотопии, переводящей узел, лежащий в плоскости, в тривиальный узел, можно выбрать также лежащими в плоскости.

Теорема Шёнфлиса. Любая ломаная без самопересечений в плоскости изотопна (в этой плоскости) треугольнику.

Это усиленная версия следующего выдающегося результата.

Теорема Жордана. Любая замкнутая несамопересекающаяся ломаная $L$ в плоскости $\mathbb{R}^{2}$ разбивает эту плоскость в точности на две части, т.е. $\mathbb{R}^{2}-L-$ несвязное множсество, являющееся объединением двух связных множеств.

Подмножество плоскости называется связным, если любые две точки этого подмножества можно соединить ломаной, в нем лежащей.

Алгоритмическое обглснение почему теорема Жордана ( значит и теорема Шёнфлиса) нетривиальна, и доказательство теоремы Жордана см. в $\$ 1.3$ «Число пересечений для ломаных на плоскости» [Sk18], [Sk]. 
Утверждение 3.2. Предположим, что существует такая точка узла, что если мы идем вдоль узла, начиная с этой точки, то на некоторой диаграмме мы сначала встречаем только переходи, а затем толъко проходы. Тогда этот узел изотопен тривиалъному узлу.6

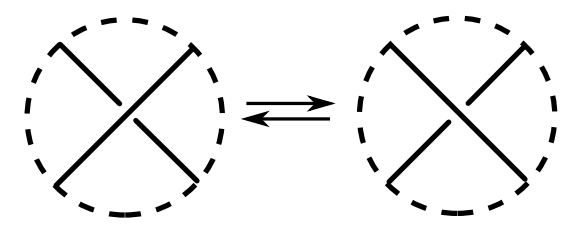

Рис. 8: Изменение перекрестка. Плоские диаграммы совпадают вне кругов, ограниченных пунктирном. Никакие другие ребра плоских диаграмм, кроме показанных на рисунке, не пересекаются с этими кругами. (Те же соглашения приняты на рис. 9, 10, 11, 12 и 21.)

Изменение перекрестка - это замена перехода на проход или наоборот, см. рис. 8 .

Очевидно, после любого изменения перекрестка в крайних слева диаграммах трилистника и восьмерки, показанных на рис. 1, получится диаграмма узла, изотопного тривиальному.

Лемма 3.3. Любая диаграмма узла может быть преобразована изменениями перекрестков в диаграмму узла, изотопного тривиальному.7
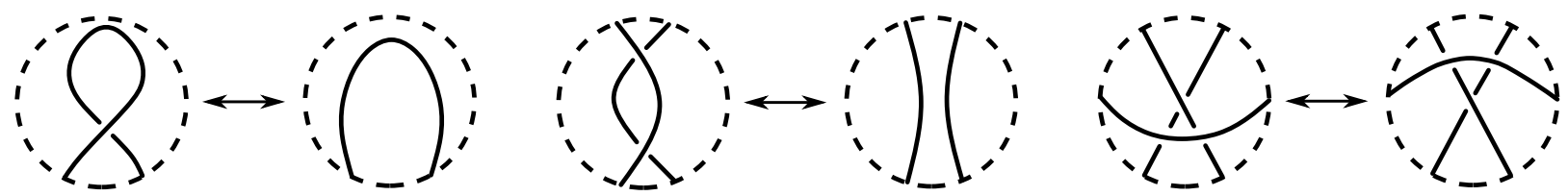

Рис. 9: Движения Рейдемейстера
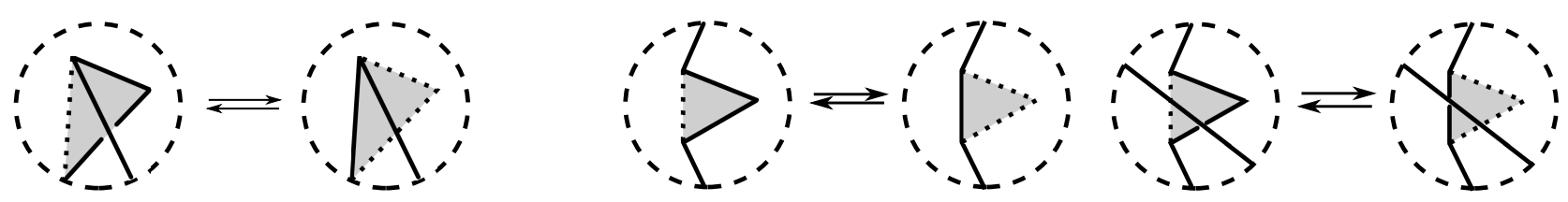

Рис. 10: Слева: к строгому определению первого движения Рейдемейстера В середине, справа: движения изотопии плоскости

В этом тексте вместо изучения узлов с точностью до изотопии, мы будем изучать диаграммы узлов с точностью до эквивалентности, порожденной движениями Рейдемейстеpa (см. рис. 9) 8 и движениями изотопии плоскости (см. рис. 10 в середине и справа). Т.е. мы будем использовать без доказательства следующий результат.

Теорема 3.4 (Рейдемейстер). Два узла изотопны тогда и толъко тогда, когда некоторая диаграмма первого узла может быть получена из некоторой диаграммы второго узла с помощью движений Рейдемейстера и движений изотопии плоскости.

\footnotetext{
${ }^{6}$ Это утверждение будет мотивировкой для введения Арф-инварианта (\$5). Доказательство иллюстрирует в малых размерностях основные идеи выдающегося доказательства Зимана многомерной теоремы о незаузленности сфер, см. обзор [Sk16c, теорема 2.3].

7 Эта простая лемма будет использована для построения инвариантов, использующего рекурсию (скейн-

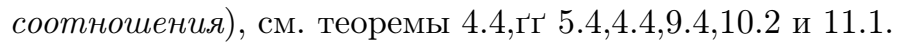

${ }^{8}$ Строгое определение первого движения Рейдемейстера легко дается с помощью рис. 10 слева. У других движений Рейдемейстера есть аналогичные строгие определения. Вы можете использовать неформальное описание движений Рейдемейстера на рис. 9 и, таким образом, не пользоваться движениями изотопии плоскости. См. сноску 9 .
} 
Cм. [PS96, §1.7] 9 Справедливы также аналоги леммы 3.3 и теоремы 3.4 для зацеплений.

\section{4 Гауссов коэффициент зацепления по модулю 2}

Предположим, что существует изотопия между двумя двухкомпонентными зацеплениями, и вторая компонента фиксирована в процессе изотопии. Тогда след первой компоненты самопересекающийся цилиндр, не имеющий общих точек со второй компонентой. Если после изотопии компоненты расцеплены, то цилиндр можно дополнить до самопересекающегося диска, не имеющего общих точек со второй компонентой. Это наблюдение, вместе с [Sk, лемма 4.3.2 о проекции], мотивирует следующее определение.

Коэффициентом зацепления по модулю два $\mathrm{lk}_{2}$ плоской диаграммы двухкомпонентного зацепления называется взятое по модулю 2 число таких перекрестков диаграммы, для которых первая компонента проходит над второй компонентой.

Задача 4.1. Найдите коэфбициент зацепления по модулю 2 для диаграмм на рис. 4 и для пар колеи, Борромео на рис. 5.b.

Лемма 4.2. Коэфбициент зацепления по модулю 2 сохраняется при движениях Рейдемейcmepa.

Эта лемма легко доказывается отдельно для каждого движения Рейдемейстера.

По лемме 4.2 коэффициент зацепления по модулю 2 двухкомпонентного зацепления (или даже его изотопического класса) можно корректно определить как коэффициент зацепления по модулю 2 любой диаграммы этого зацепления.

Будем использовать без доказательства следующую лемму о четности: любые две замкнутые ломаные на плоскости, вершины которых находятся в общем положении, пересекаются в четном числе точек. Обсуждение и доказательство этой леммы можно найти в 1.3 «Число пересечений для ломаных на плоскости» [Sk18, [Sk].

Утверждение 4.3. (а) Перестановка компонент двухкомпонентного зацепления сохраняет коэфбициент зацепления по модулю 2.

(b) Существует двухкомпонентное защепление, не изотопное тривиальному зацеплению, но имеющее нулевой коэффициент зацепления по модулю 2.

П. (b) доказывается с помощью иелочисленного коэффициента зацепления, см. ф88.

${ }^{9}$ Так как в [PS96, \$1.6] нет такого же строгого определения для движений Рейдемейстера как для движений изотопии плоскости, рассуждения в [PS96, §1.7] не являются строгим доказательством. По-видимому, строгое доказательство может быть получено с использованием строгого определения движений Рейдемейстера.

Это также показывает, что наличие движений изотопии плоскости в утверждении из [PS96, §1.7] не делает само утверждение строгим, поэтому их следует избегать. Работая на интуитивном уровне, движениями изотопии плоскости лучше не пользоваться. С помощью приведенного ниже альтернативного строгого определения движения изотопии плоскости выражаются через движения Рейдемейстера, а потому не должны упоминаться в формулировке теоремы.

Приведем альтернативное строгое определение первого движения Рейдемейстера. У других движений Рейдемейстера есть аналогичные строгие определения. Возьмем на плоскости замкнутую несамопересекающуюся ломаную $L$, внутренность которой (см. теорему Жордана в замечании 3.1) пересекает диаграмму $D$ по несамопересекающейся ломаной $M$, соединяющей две точки на $L$. Обозначим через $N$ замкнутую несамопересекающуюся ломаную во внутренности ломаной $L$, для которой $N \cap L=\emptyset, N \cap M$ - одна точка, а $M \cup N$ - (самопересекающаяся) ломаная общего положения. Первое движение Рейдемейстера - это замена $M$ на $M \cup N$ в $D$ с любой «информацией» в появившемся перекрестке. 
Теорема 4.4. Существует единственный изотопический инвариант $\mathrm{lk}_{2}$ двухкомпонентных зачеплений, принимающий значения в $\mathbb{Z}_{2}$, равный нулю на тривиальном зачеплении и такой, что для любых зацеплений $K_{+}$и $K_{-}$, диаграммы которых отличаются изменением перекрестка $A$,

$$
\mathrm{lk}_{2} K_{+}-\mathrm{lk}_{2} K_{-}= \begin{cases}1 & A-\text { пересечение различных компонент; } \\ 0 & A-\text { самопересечение одной из компонент. }\end{cases}
$$

Утверждение 4.5. Если коэффициент заиепления по модулю 2 двух (непересекающихся контуров) треугольников в пространстве равен нулю, то зацепление, образованное этими треугольниками, изотопно тривиальному.

Доказательство, по-видимому, не опубликовано, однако оно не очень сложное. Мы призываем читателя опубликовать подробное рассуждение. Сp. [Ko19].

\section{5 Арф-инвариант}

Рассмотрим плоскую диаграмму некоторого узла и ее точку $P$, не являющуюся перекрестком. Назовем $P$ отмеченной точкой. Неупорядоченная пара перекрестков $A, B$ называется скрещивающейся (или $P$-скрещивающейся), если, обходя диаграмму в каком-нибудь направлении, начиная с $P$, и отмечая только перекрестки в $A$ и в $B$, мы сначала встретим переход в $A$, затем проход в $B$, затем проход в $A$ и, наконец, переход в $B$. Далее, $P$ - $A p \phi$ инвариантом $\operatorname{arf}_{P}$ плоской диаграммы называется четность числа ее $P$-скрещивающихся пар перекрестков.

Задача 5.1. (а) Если Р-Арф-инвариант плоской диаграммы не равен нулю, то Р не может быть точкой из утверждения [3.2.

(b) Найдите P-Арф-инвариант (какой-нибудв плоской диаграммъ) тривиального узла, трилистника и восъмерки (при Вашем выборе отмеченной точки $P$ ).

Лемма 5.2. (а) P-Арф-инвариант не зависит от выбора отмеченной точки $P$.

(b) Арф-инвариант плоской диаграммы сохраняется при движениях Рейдемейстера.

Согласно п. (а) Арф-инвариант плоской диаграммы можно корректно определить как ее $P$-Арф-инвариант для произвольной отмеченной точки $P$. Поэтому формулировка п. (b) осмыслена. Согласно п. (b) Apф-инвариант arf узла (или даже изотопического класса узлов) можно корректно определить как Арф-инвариант произвольной плоской диаграммы этого узла.

Указания. (а) Будем перемещать отмеченную точку вдоль плоской диаграммы. Тогда достаточно показать, что Арф-инвариант не изменяется, когда отмеченная точка проходит через перекресток.

(b) Докажите утверждение для каждого движения Рейдемейстера отдельно, всякий раз выбирая отмеченную точку наиболее удобным образом.

Утверждение 5.3. Существует узел, не изотопный тривиальному, Арф-инвариант которого равен нулю.

Это доказывается с помощью инварианта Кэссона, см. §9.

Теорема 5.4. Существует единственный изотопический инвариант arf узлов, принимающий значения в $\mathbb{Z}_{2}$, равный нулю на тривиальном узле и такой, что

$$
\operatorname{arf} K_{+}-\operatorname{arf} K_{-}=\operatorname{lk}_{2} K_{0}
$$




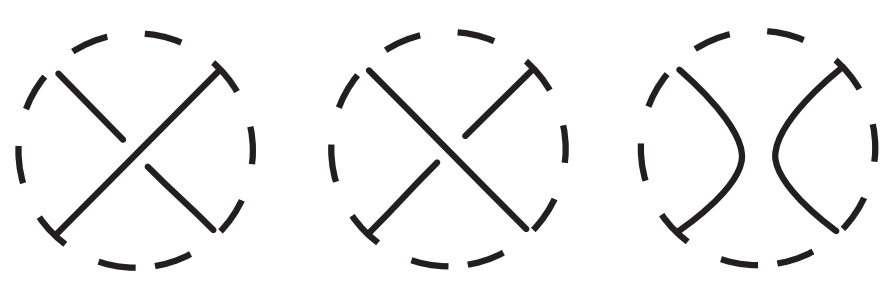

Рис. 11: Зацепления $K_{+}, K_{-}, K_{0}$

для любых узлов $K_{+}$и $K_{-}$, диаграммы которых отличаются как показано на рис. 11, причем $K_{0}$ является двухкомпонентным защеплением. (Последнее эквивалентно существованию ориентачии, для которой рис. 11 превращается в рис. 21.)

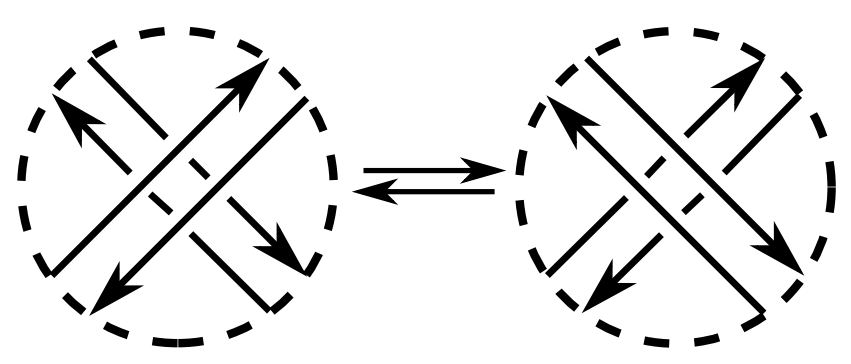

Рис. 12: Пронос

Утверждение 5.5. Два узла называются Арф-эквивалентными, если какал-нибудъ диаграмма первого узла (с некоторой ориентаиией) может быть преобразована в какую-нибудъ диаграмму второго узла (с некоторой ориентаиией) движениями Рейдемейстера и с помощъю проносов, показанных на рис. 12.

(а) Если два узла Арф-эквивалентны, то их Арф-инварианты совпадают.

(b) Восъмерка Арф-эквивалентна трилистнику.

(с) [Ка87, стр. 75-78] Если у двух узлов Арф-инварианты совпадают, то эти узль Арфэквивалентны.

\section{6 Приложение: правильные раскраски}

Этот раздел иллюстрирует связь с раскрасками в комбинаторике Ra20. Он использует только материал разделов 11 и 2. Подробнее про правильные раскраски см. в [Pr98].

Дугой на плоской диаграмме (узла или зацепления) называется связный фрагмент ломаной, идущий от одного прохода до следующего. Правильная раскраска плоской диаграммы (узла или зацепления) - это такая раскраска ее дуг в три цвета, что по крайней мере два цвета использовано, и в каждом перекрестке встречаются либо все три цвета, либо только один цвет. Плоская диаграмма (узла или зацепления) называется раскрашиваемой в три цвета если ее можно правильно раскрасить.

Задача 6.1. Для каждого из следующих узлов или защеплений возъмите любую плоскую диаграмму и определите, является ли она раскрашиваемой в три ивета:

(а) тривиальный узел; (b) трилистник; (c) восъмерка.

(d-i) защепления на рис. 4 и 5. b.

Лемма 6.2 ([Pr95, стр. 29-30, теорема 4.1]). Раскрашиваемость в три ивета плоской диаграммы сохраняется при движениях Рейдемейстера. 
Теорема 6.3. (а) Ни одно из зачеплений на рис. 4 и囵 (кроме тривиального зацепления) не изотопно тривиальному зацеплению.

(b) Узел $5_{1}$ не изотопен тривиальному узлу.

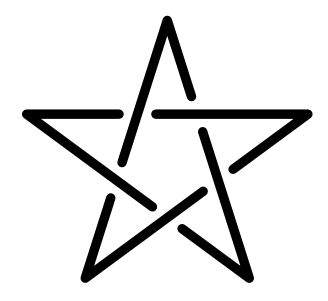

Рис. 13: Узел 51

\section{7 Ориентированные узлы и зацепления; связные суммы}

Вы знаете, что такое ориентированная ломаная, так что вы также знаете, что такое ориентированный узел (рис. 14).
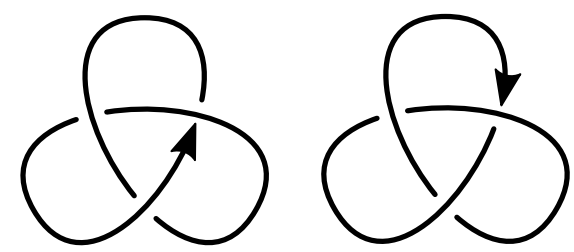

Рис. 14: Два трилистника с противоположными ориентациями

Неформальное понятие и строгое определение изотопии ориентированных узлов даются аналогично изотопии узлов.

Утверждение 7.1. Изотопные ориентированные ломаные без самопересечений на плоскости и на сфере определяются аналогично изотопным ориентированным узлам в пространстве.

(а) Ориентированный сферический треугольник изотопен на сфере тому же треугольнику с противоположной ориентацией.

(b) Аналог пункта (а) для плоскости неверен.

Утверждение 7.2. Следующие пары узлов с противоположными ориентациями изотопны: два тривиальных узла; два трилистника; две восъмерки.

Теорема 7.3 (Троттер, 1964). Существует ориентированный узел, не изотопный такому же узлу с противоположной ориентацией.

Этот факт доказывается с использованием полиномов Джонса [PS96, §3], [CDM, §2.4]; доказательство выходит за рамки данного текста.

Связная сумма \# ориентированных узлов определена на рис. 15, Связная сумма \# (неориентированных) узлов определяется аналогично (забудьте про стрелки). Ни та, ни другая операция не является корректно определенной на множестве узлов или ориентированных узлов соответственно; см. также замечание 17.5. Так что мы обозначаем через $K \# L$ любую из связных сумм узлов или ориентированных узлов $K$ и $L$. 


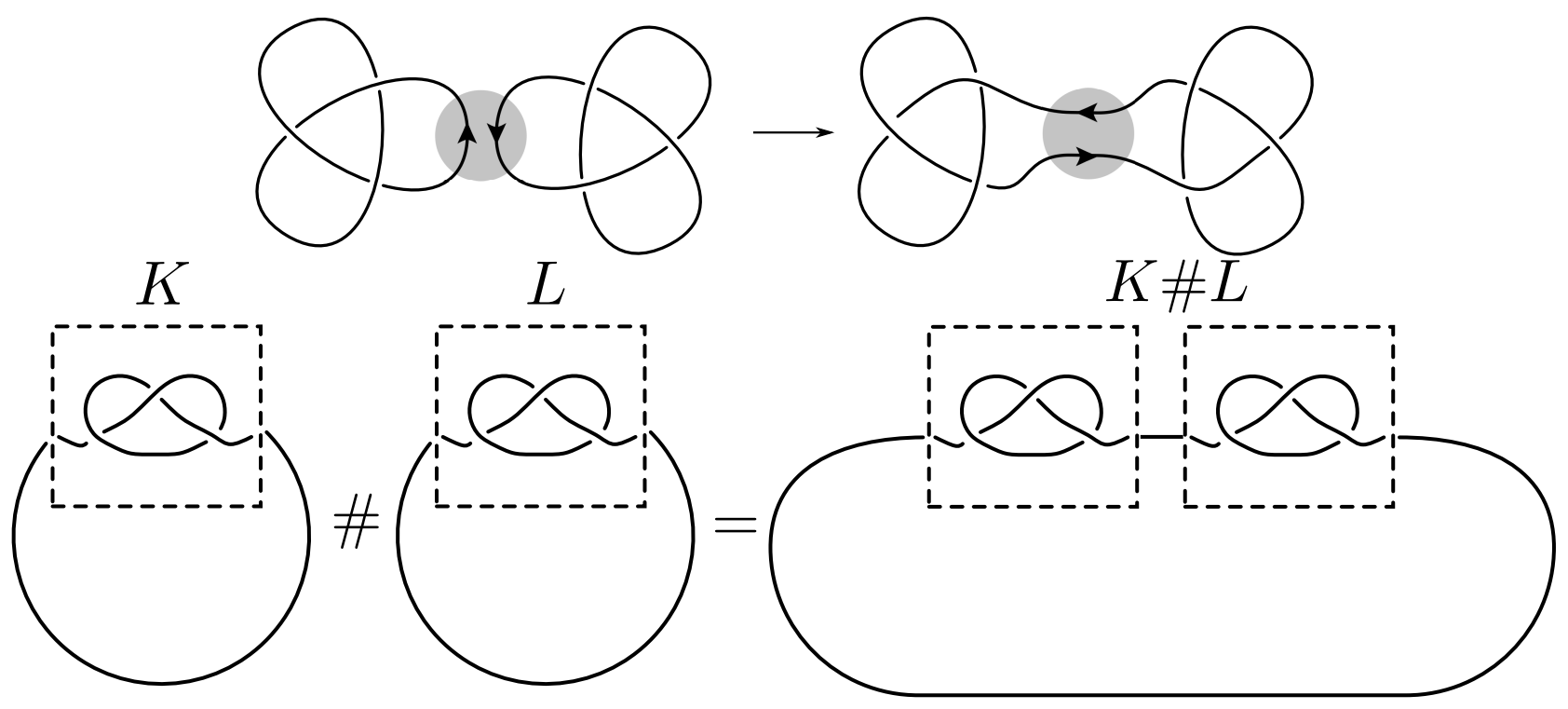

Рис. 15: Связная сумма узлов

Утверждение 7.4. Для любых ориентированных узлов $K, L, M$ и тривиального ориентированного узла $O$ имеем

(a) $K \# O=K . \quad$ (b) $K \# L=L \# K . \quad$ (c) $(K \# L) \# M=K \#(L \# M)$.

(d) Для любых неориентированных узлов $K, L$ выполнено $\operatorname{arf}(K \# L)=\operatorname{arf} K+\operatorname{arf} L$.

(Строгий смысл пункта (а) - «существует связная сумма узлов $K$ и O, изотопная узлу $K »$. Строгий смысл пунктов (b,c) и (d) аналогичен. См., впрочем, замечание 7.5.)

Набросок доказательства. (а) См. рис. 16.

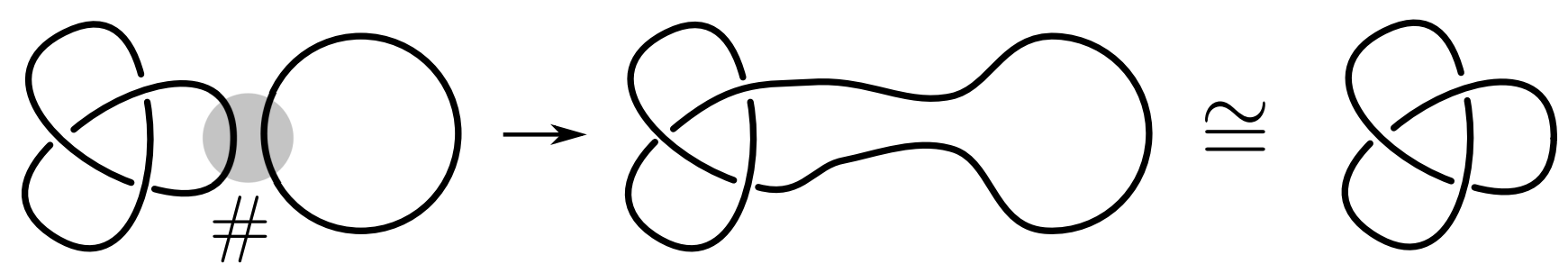

Рис. 16: Доказательство равенства $K \# O=K$

(b) Достаточно взять «маленький» узел, изотопный узлу $L$ и «провести» его через узел $K$, см. рис. 17 слева.

(c) Узлы из левой и правой частей равенства изотопны узлу на рис. 17 справа.

(d) Выберите отмеченную точку $P$ близко к «месту соединения» узлов. Проверьте, что всякая $P$-скрещивающаяся пара перекрестков в $K \# L$ получается либо из скрещивающейся пары перекрестков в $K$, либо из скрещивающейся пары перекрестков в $L$.

Замечание 7.5. Изотопический класс узла - это множество всех узлов, ему изотопных. Ориентированный изотопический класс $[K \# L]$ связной суммы двух ориентированных изотопических классов $[K],[L]$ ориентированных узлов $K, L$ не зависит от выборов, сделанных в прочессе построения, и от выбора представителей $K, L$ классов $[K],[L]$. Следовательно, связная сумма ориентированных изотопических классов ориентированных узлов корректно определена как $[K] \#[L]:=[K \# L]$, см. [Sk15, замечание 2.3.а]. Для изотопических классов неориентированных узлов связная сумма не является корректно определенной операчией $[C S K]$. 

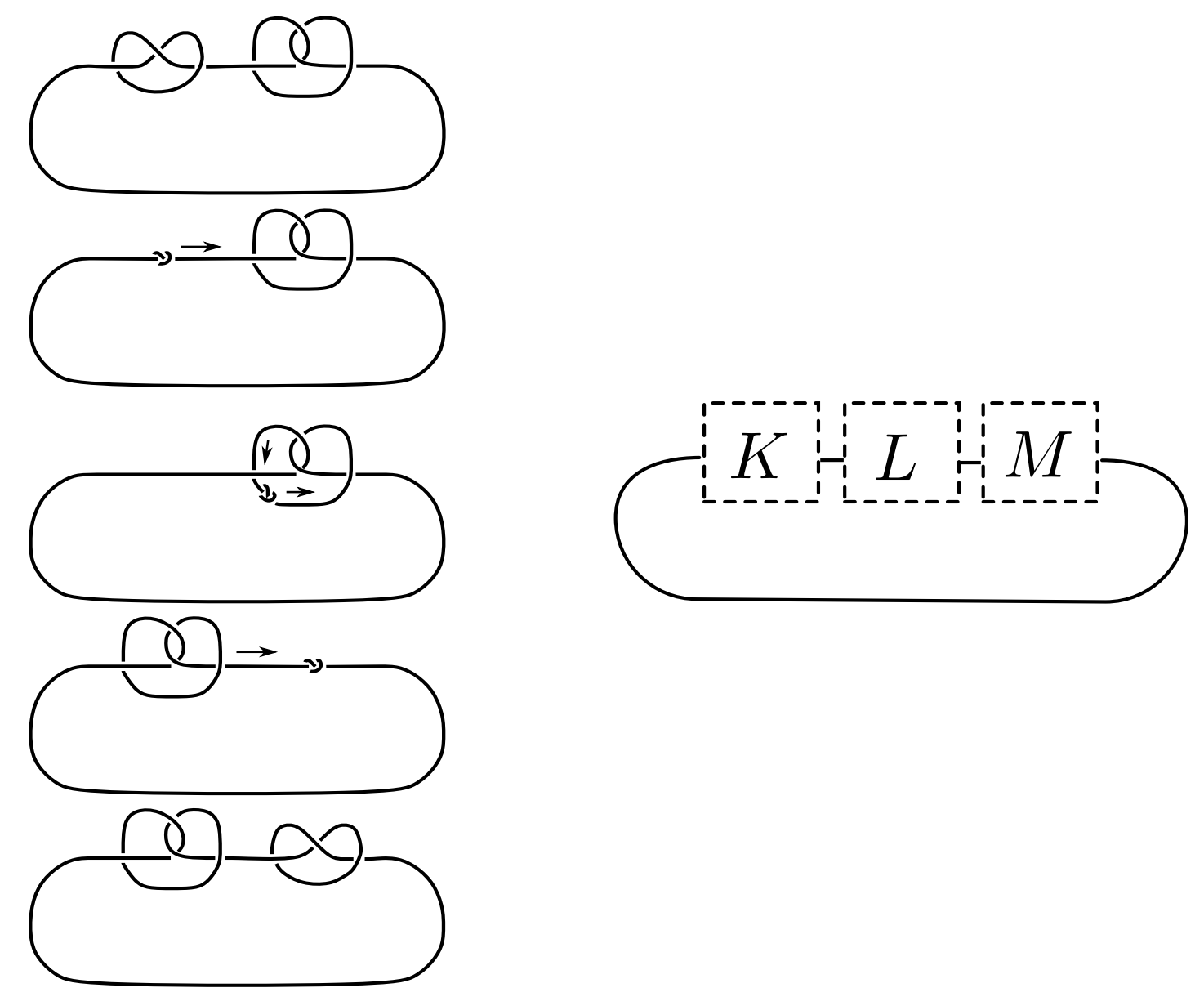

Рис. 17: Доказательства равенств $K \# L=L \# K$ (слева) и $(K \# L) \# M=K \#(L \# M)$ (справа)

Теорема 7.6. Пусть $K, L, M$ - изотопические классы ориентированных узлов, а $O-$ изотопический класс ориентированного тривиалъного узла. Тогда

(a) если $K \# L=O$, mо $K=L=O$;

(b) если $K \# L=K \# M$, mо $L=M$.

Доказательство выходит за рамки данного текста, см. [PS96, теорема 1.5]. (В этом отрывке из [PS96] необходимо всюду заменить «узел» на «ориентированный узел» ввиду замечания 7.5.)
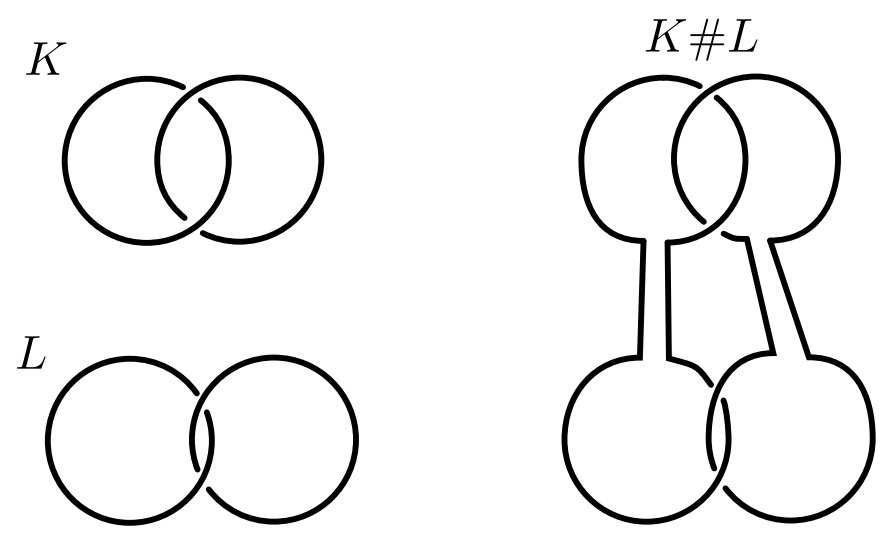

Рис. 18: Связная сумма зацеплений

Связная сумма \# зацеплений (упорядоченных или нет, ориентированных или нет) определяется аналогично связной сумме узлов, см. рис. 18. Эта операция не является корректно 
определенной для зацеплений, и замечание 7.8 показывает, что эта операция также не дает корректно определенного понятия связной суммы изотопических классов зацеплений. Так что мы обозначаем через $K \# L$ любую связную сумму зацеплений $K$ и $L$.

Утверждение 7.7. (a,b,c) Докажите аналоги утверждений 7.4. $a, b, c$ для зацеплений.

(d) Для любых неориентированных двухкомпонентных защеплений $K, L$ выполнено $\operatorname{lk}_{2}(K \# L)=$ $\mathrm{lk}_{2} K+\mathrm{lk}_{2} L$.

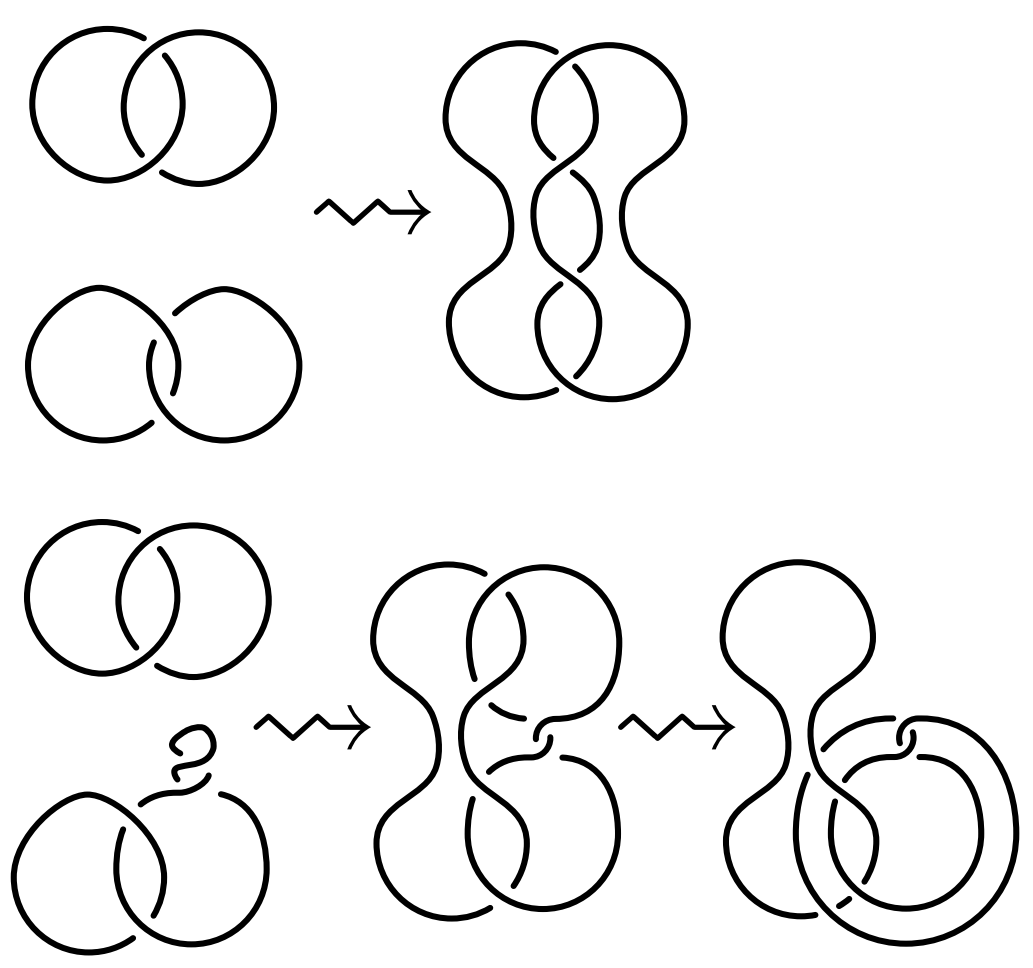

Рис. 19: Связная сумма изотопических классов зацеплений не определена корректно

Замечание 7.8. Существуют две изотопные пары $(K, L)$ u $\left(K^{\prime}, L^{\prime}\right)$ двухкомпонентных зацеплений такие, что некоторые связные суммы $K \# L$ и $K^{\prime} \# L^{\prime}$ не изотопны. (Зацепления могут быть упорядочены или нет, ориентированы или нет - всего получается 4 утверждения.) Для случая неупорядоченных защеплений пример дается парой одинаковых защеплений, каждое из которых состоит из трилистника и тривиального узла, содержащихся в непересекающихся кубах, ср. [PS96, рис. 3.16]. Пример для случая упорядоченных защеплений содержится в [As]. На рис. 19 показан другой пример, предложенный А. Рябичевым.

\section{8 Гауссов коэффициент зацепления}

Пусть $(\overrightarrow{A B}, \overrightarrow{C D})$ - упорядоченная пара векторов (ориентированных отрезков) на плоскости, пересекающихся в точке $P$. Определим знак точки $P$ как +1 , если $A B C$ ориентирован по часовой стрелке, и как -1 в противном случае (рис. 201).

Коэффициент зацепления $\mathrm{lk}$ плоской диаграммы ориентированного двухкомпонентного зацепления - это сумма знаков всех точек пересечения на диаграмме, в которых первая компонента проходит над второй компонентой. В каждом перекрестке первый (второй) вектор - это звено первой (второй) компоненты.

Задача 8.1. Найдите коэфбичиент зацепления для (некоторой плоской диаграммы) зацепления Хопфа и пары колеи, Борромео, выбрав ориентацию компонент самостоятельно. 


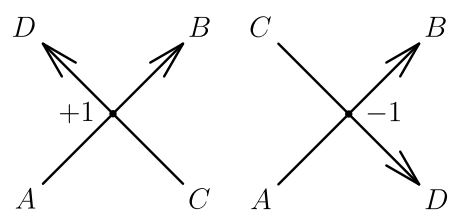

Рис. 20: Знак точки пересечения

Лемма 8.2. Коэффиииент зачепления сохраняется при движениях Рейдемейстера.

Доказательство аналогично доказательству леммы 4.2. Достаточно проверить, что знаки всех перекрестков не изменяются.

По лемме 8.2 коэффициент зацепления ориентированного двухкомпонентного зацепления (или его класса изотопности) корректно определен как коэффициент зацепления любой плоской диаграммы зацепления.

Модуль коэфбициента зацепления (неориентированного) двухкомпонентного зацепления (или его класса изотопии) корректно определен вне зависимости от ориентации компонент.

Будем использовать без доказательства следующую лемму о тривиальности: для любых двух замкнутых ломаных в плоскости, вершины которых находятся в общем положении, сумма знаков их точек пересечения равна нулю. Обсуждение и доказательство см. в $§ 1.3$ «Число пересечений для ломаных на плоскости» в [Sk18], [Sk].

Утверждение 8.3. (а) Перестановка компонент меняет знак коэфбициента зацепления.

(b) Изменение ориентации любой компоненты меняет знак коэффициента зацепления.

(c) Существует ориентированное двухкомпонентное зацепление с коэфбициентом заиепления -5 .

(d) Для любой связной суммы $K \# L$ ориентированных двухкомпонентных зацеплений $K, L$ имеем $\operatorname{lk}(K \# L)=\operatorname{lk} K+\mathrm{lk} L$.

(е) Существует двухкомпонентное защепление, не изотопное тривиальному зацеплению, но имеющеељ'нулевой коэфбициент зацепления.

П. (е) доказывается с помощью многочлена Александера-Конвея, см. \$10.

Теорема 8.4. Существует единственный иелочисленный изотопический инвариант $\mathrm{lk}_{2}$ ориентированных двухкомпонентных защеплений, принимающий значение 0 на тривиальном защеплении и такой, что для любых зачеплений $K_{+}$и $K_{-}$, диаграммы которых отличаются изменением перекрестка $A$, как показано на рис. [21,

$$
\operatorname{lk} K_{+}-\mathrm{lk} K_{-}= \begin{cases}1 & A-\text { пересечение различных компонент; } \\ 0 & A-\text { самопересечение одной из компонент. }\end{cases}
$$

Доказательство аналогично доказательству теоремы 4.4.

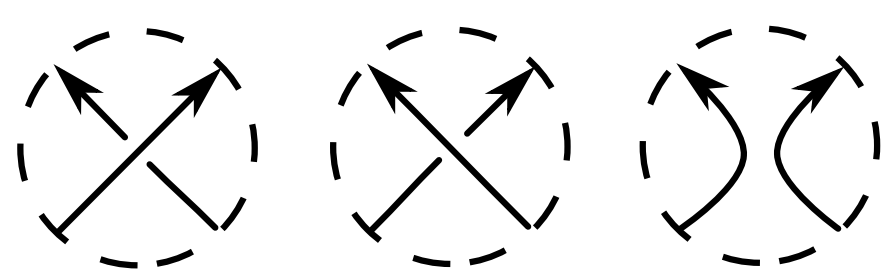

Рис. 21: Ориентированные зацепления $K_{+}, K_{-}, K_{0}$ 


\section{9 Инвариант Кэссона}

Знак перекрестка ориентированной плоской диаграммы узла определен после рисунка 20, первый (второй) вектор - это вектор перехода (прохода). Очевидно, знак не зависит от ориентации диаграммы, и таким образом определен для неориентированных диаграмм.

Знак $P$-скрещивающейся пары перекрестков на плоской диаграмме узла (для любой отмеченной точки $P$ ) - это произведение знаков соответствующих перекрестков.

$P$-инвариант Кэссона плоской диаграммы - это сумма знаков всех $P$-скрещивающихся пар перекрестков.

Задача 9.1. (а) Аналог задачи 5.1.

(b) Нарисуйте плоскую диаграмму узла и отмеченную точку P такие, что P-инвариант Кэссона плоской диаграммы равен -5 .

Лемма 9.2. (a,b) Аналог леммы 5.2. $a, b$ для инварианта Кэссона.

Поэтому инвариант (число) Кэссона $c_{2}$ плоской диаграммы узла (или даже изотопического класса узла) является корректно определенным инвариантом, если положить его равным $P$-инварианту Кэссона любой плоской диаграммы этого узла с любой отмеченной точкой $P$.

Утверждение 9.3. (a,b) Аналог утверждений 7.4. $d$ и 5.3 для инварианта Кэссона.

П. (b) доказывается с помощью многочлена Александера-Конвея, см. \$10.

Обозначим через $D_{+}, D_{-}, D_{0}$ любые три диаграммы ориентированных (узлов или) зацеплений, отличающиеся, как показано на рис. 21 (см. соглашения о рисунках в подписи к рис. 8). Также обозначим через $K_{+}, K_{-}, K_{0}$ любые три зацепления с диаграммами $D_{+}, D_{-}, D_{0}$.

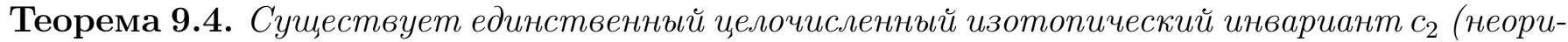
ентированных) узлов, который равен 0 для тривиального узла, и такой что

$$
c_{2}\left(K_{+}\right)-c_{2}\left(K_{-}\right)=\operatorname{lk} K_{0}
$$

для любых узлов $K_{+}$и $K_{-}$, диаграммы которых отличаются как показано на рис. 21. (Oтметим что $K_{0}$ обязательно является двухкомпонентным зацеплением; число $1 \mathrm{k} K_{0}$ определено корректно, так как изменение ориентации обеих компонент ориентированного заиепления не меняет коэфбициента зацепления.)

\section{0 Полином Александера-Конвея}

Этот раздел использует только материал разделов 1, 2 и 7 (кроме утверждений 10.4.b,c, использующих также разделы 8 и 9 9).

Задача 10.1. (а) Существует единственный изотопический инвариант ориентированных трехкомпонентных защеплений arf со значениями в $\mathbb{Z}_{2}$, принимающий значение 0 на тривиальном защеплении и такой, что

$$
\operatorname{arf} K_{+}-\operatorname{arf} K_{-}= \begin{cases}\operatorname{lk}_{2} K_{0} & \text { в точке пересечения различных компонент; } \\ 0 & \text { в точке самопересечения одной из компонент. }\end{cases}
$$


(Здесь $\mathrm{lk}_{2} K_{0}$ определено, так как $K_{0}$ обязательно является двухкомпонентным зацеплением. 10

(b) Предполагая существование инварианта arf из п. (а), вычислите его для колеи, Борромео (при вашем выборе ориентаций компонент).

Теорема 10.2. Существует единственная бесконечная последовательность $c_{-1}=0, c_{0}, c_{1}, c_{2}, \ldots$ целочисленных инвариантов ориентированных неупорядоченных зачеплений такая, что

- на тривиальном узле $c_{0}=1$ и $c_{1}=c_{2}=\ldots=0$;

- для любого $n \geq 0$ и зацеплений $K_{+}, K_{-}, K_{0}$ с рис. 21] выполнено

$$
c_{n}\left(K_{+}\right)-c_{n}\left(K_{-}\right)=c_{n-1}\left(K_{0}\right) .
$$

Доказательства существования в утверждении 10.1.а и теореме 10.2 выходят за рамки данного текста. 11 Доказательство см. в [Al28], [Ka06, §3-§5], [Ka06], [Ma18, §5.5 и §5.6], [Ga20. Про связь с правильными раскрасками см. в [Ka06', §6].

Многочлен $C(K)(t):=c_{0}(K)+c_{1}(K) t+c_{2}(K) t^{2}+\ldots$ называется многочленом Конвел, см. утверждение 10.4. же быстро, как и один из них. Формула из теоремы 10.2 эквивалентна равенству

$$
C\left(K_{+}\right)-C\left(K_{-}\right)=t C\left(K_{0}\right) \text {. }
$$

Задача 10.3. Найдите многочлены Конвея следующих зачеплений (выберите сами ориентацию для каждой компоненты).

(а) тривиальное зацепление с двумя компонентами;

(b) тривиальное зацепление с $n$ компонентами;

(c) зачепление Хопфа; (d) трилистник; (е) восъмерка;

(f) зачепление Уайтхеда; (g) кольиа Борромео; (h) узел $5_{1}$.

Утверждение 10.4. (а) Имеет место равенство $c_{0}(K)=1$ если $K$ узел, и $c_{0}(K)=0$ в противном случае (т.е. если $K$ имеет более одной компоненты).

(b) Если $K-$ узел, то $c_{2 j+1}(K)=0$, и с $c_{2}$ - инвариант Кэссона.

(c) Если $K$ - двухкомпонентное защепление, то $c_{2 j}(K)=0, u c_{1}-$ коэфбициент защепления.

(d) Если $K$ - любое $k$-компонентное зацепление, то $c_{j}(K)=0$, если $j \leq k-2$ или $j-k$ четно.

(е) Для каждого узла или защепления все инварианты $c_{n}$, кроме конечного числа, обращаютея в нуль.

Утверждение 10.5. (а) Изменение ориентации всех компонент зацепления (в частности, изменение ориентации узла) сохраняет многочлен Конвея.

(b) [CDM, 2.3.4] Существует двухкомпонентное защепление такое, что изменение ориентации одной его компоненты меняет степень многочлена Конвея (в частности, такое изменение ни сохраняет многочлен Конвея, ни меняет его знак).

(с) Для любой связной суммы $K \# L$ узлов $K, L$ верно $C(K \# L)=C(K) C(L)$.

\footnotetext{
10Это утверждение - частный случай версии по модулю 2 теоремы 10.2 было бы интересно получить его прямое доказательство, поскольку оно могло бы проиллюстрировать идею доказательства теоремы 10.2 на простейшем из нетривиальных случаев.

Теорема 5.4 является аналогом данного утверждения для узлов (которые являются однокомпонентными зацеплениями). Определение инварианта arf из \$5применимо только для узлов, и здесь мы пытаемся обобщить его на трехкомпонентные зацепления.

${ }^{11}$ Не вполне ясно, упорядоченные или неупорядоченные зацепления имеются в виду в [CDM, §2.3.1]. Поэтому мы приводимВывод сильной версии (для неупорядоченных зацеплений) из слабой (для упорядоченных зацеплений) см. в
} 
Утверждение 10.6. Зацепление называется разделяемым, если оно изотопно зацеплению, компоненты которого содержатся в непересекающихся шарах.

(а) Зацепление Хопфа, зацепление Уайтхеда и кольца Борромео не являются разделяемыми зачеплениями.

(b) Коэфбициент зацепления разделяемого зацепления равен нулю.

(с) Многочлен Конвея разделяемого зачепления нулевой.

\section{1 Инварианты Васильева-Гусарова}

Этот раздел использует только материал разделов 1, 2 и 7 (кроме задачи 11.3, 2, использующей также раздел 9).

Сингулярныц (ориентированный) узел - замкнутая ориентированная ломаная в $\mathbb{R}^{3}$, все точки самопересечения которой являются простыми двойными (эти точки не являются вершинами ломаной). Два сингулярных узла изотопны, если существует сохраняющий ориентацию кусочно-линейный гомеоморфизм $h: \mathbb{R}^{3} \rightarrow \mathbb{R}^{3}$, переводящий первый узел во второй с сохранением ориентации. Обозначим через $\Sigma$ множество всех изотопических классов сингулярных узлов.

Хордовая диаграмма - слово из $2 n$ букв, среди которых ровно $n$ различных, причем каждая буква встречается дважды. Слова, отличающиеся циклическим сдвигом, считаются одинаковыми. Хордовую диаграмму обычно изображают в виде ориентированной окружности с набором хорд, cp. [Sk20, §1.5]. Для произвольного сингулярного узла $K$ обозначим через $\sigma(K)$ хордовую диаграмму, построенную следующим образом. Будем равномерно двигаться по ориентированной окружности в направлении ориентации, и для каждой ее точки $A$ рассмотрим соответствующую точку $f(A)$ сингулярного узла $K$. Соединим две точки окружности хордой, если они обе соответствуют некоторой точке самопересечения сингулярного узла $K$ [PS96, 4.8], [CDM, 3.4.1] 12

$\lambda$

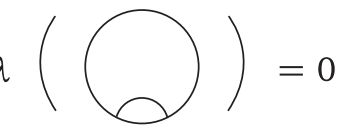

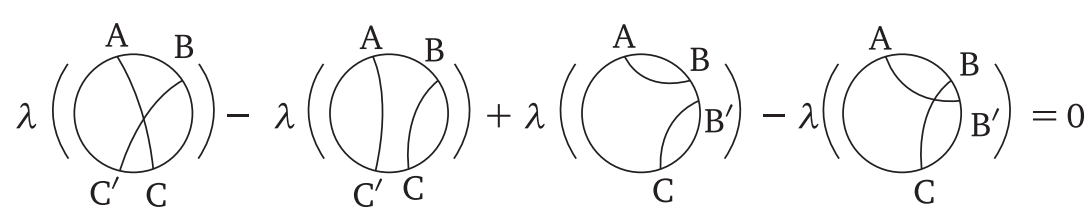

Рис. 22: Одночленное и четырехчленное соотношения

Теорема 11.1. Пусть $n \geq 0$ - целое $и \lambda: \delta_{n} \rightarrow \mathbb{R}-$ функиия из множества $\delta_{n}$ всех хордовых диаграмм с п хордами. Функиия $\lambda$ удовлетворяет одночленному и четырехчленному соотношениям с рис. 22 тогда и только тогда, когда существует отображение $v: \Sigma \rightarrow \mathbb{R}$ (т.е. инвариант сингулярных узлов), для которого

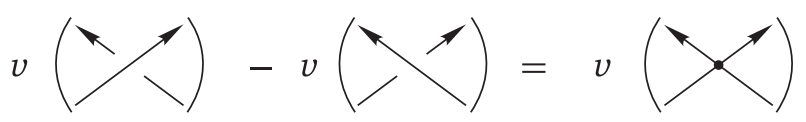

Рис. 23: Скейн-соотношение Васильева (обратите внимание на разницу с рис. 21)

(1) Выполнено скейн-соотношение Васильева с рис. 23,

\footnotetext{
${ }^{12}$ Другими словами, рассмотрим произвольное кусочно-линейное отображение $f: S^{1} \rightarrow \mathbb{R}^{3}$, образ которого есть $K$. Проведем хорду $X Y$ для каждой пары точек $X, Y$ такой, что $f(X)=f(Y)$. Хордовую диаграмму не следует путать с диаграммой Гаусса (проекции) узла $g: S^{1} \rightarrow \mathbb{R}^{3}$ (несингулярного), которая определяется как (произвольным образом ориентированная) хордовая диаграмма композиции проекции $\mathbb{R}^{3} \rightarrow \mathbb{R}^{2}$ с отображением $g$ [PS96, 4.8] [CDM, 1.8.4].
} 
$\left(2_{n}\right) v(K)=0$ для любого сингулярного узла $K$, имеющего более $n$ точек самопересечения,

(3) $v(K)=\lambda(\sigma(K))$ для любого сингулярного узла $K$, имеющего ровно $n$ точек самопересечения.

Доказательство выходит за рамки данного текста.

Насколько мне известно, теорема 11.1 Васильева-Концевича никогда раньше не формулировалась в таком виде, коротком и удобном для вычисления инвариантов (хотя эта формулировка неявно использовалась в процессе вычислений). Я благодарен С. Чмутову за подтверждение того, что теорема 11.1 верна и действительно эквивалентна теореме ВасильеваКонцевича в традиционной формулировке, см., например, [CDM, теорема 4.2.1], ср. [PS96, теорема 4.12].

Отображение $v: \Sigma \rightarrow \mathbb{R}$, для которой выполнено условие (1), называется инвариантом Васильева-Гусарова. Если дополнительно выполнено условие $\left(2_{n}\right)$, то $v$ называется инвариантом порядка не выше $n$.

Следующее утверждение означает, что функция $v$ из теоремы 11.1 единственна с точностью до инварианта Васильева-Гусарова порядка не выше $n-1$.

Утверждение 11.2 ([CDM, предложение 3.4.2]). Разность $v-v^{\prime}$ отображений $v, v^{\prime}: \Sigma \rightarrow \mathbb{R}$, удовлетворяющих условиям (1), (2n ) и (3), удовлетворяет условиям (1) и (2 $\left.2_{n-1}\right)$.

Задача 11.3. (а) Докажите часть «тогда» теоремы 11.1.

(0),(1),(2) Докажите часть «только тогда» теоремы 11.1 для $n=0,1,2$.

Указание. B случае $n=2$ воспользуйтесь теоремой 9.4.

(Часть «только тогда» теоремы 11.1 для $n=3$ может быть доказана с использованием коэфбичиента при $h^{3}$ в $J\left(e^{h}\right)$, где $J-t$-параметризованный многочлен Джсонса [CDM, 2.4.2, 2.4.3] [PS96, (4.6)].)

В оставшихся задачах используйте без доказательства часть «только тогда» теоремы 11.1. Далее утверждение « $(K)=x$ для любого особого узла $K$ с хордовой диаграммой $A$ » сокращенно записывается как $v(A)=x »$.

Задача 11.4. (а) Существует единственный инвариант Васильева-Гусарова $v_{2}: \Sigma \rightarrow \mathbb{R}$ порядка не выше 2 такой, что $v_{2}(O)=0$ для тривиального узла $O$, и $v_{2}(1212)=1$. (Здесъ (1212) обозначает единственную «нетривиальную» хордовую диаграмму с двумя хордами, см. [PS96, рис. 4.4], 3-я диаграмма в первом ряду.)

Указание. Это следует из теоремы 9.4, однако попробуйте вывести это из теоремь 11.1.

$\left(b, b^{\prime}, c, d\right)$ Вычислите $v_{2}$ для (произвольным образом ориентированных) правого трилистника, левого трилистника, восъмерки и узла $5_{1}$.

Задача 11.5. (а) Существует единственный инвариант Васильева-Гусарова $v_{3}: \Sigma \rightarrow \mathbb{R}$ порядка не выше 3 такой, что $v_{3}(O)=0$ для тривиального узла $O$ и левого трилистника $O$, и $v_{3}(123123)=1$. (Здесь (123123) обозначает «самую симметричную нетривиальную диаграмму с 3-я хордами», см. [РS96, рис. 4.4], 5-ая диаграмма во втором ряду.)

$\left(b, b^{\prime}, c, d\right)$ Аналог задачи 11.4, для $v_{3}$.

Указание. См. задачи 2, 3, 4аb и результаты/теоремы 11, 13, 14 из [PS96, \$4].

Задача 11.6. (а) [PS96, задача 4.4.b] Существует единственный инвариант ВасилъеваГусарова $v_{4}: \Sigma \rightarrow \mathbb{R}$ порядка не выше 4 такой, что

- $v_{4}(O)=0$ для тривиального узла $O$, левого трилистника $O$ и правого трилистника $O$

- $v_{4}(12341234)=2, v_{4}(12341432)=3, u v_{4}(12341423)=5$.

$\left(b, b^{\prime}, c, d\right)$ То же, что и в задаче 11.4, для $v_{4}$. 


\section{2 Некоторыегдоказательства, указанияг и решения}

1.1. $(\mathrm{a}, \mathrm{b})$ «Проще всего изготовить трилистник и восьмерку из веревки или шнурка, а затем попытаться получить из этих узлов все узлы, изображенные на рис. 1. Выполнить некоторые преобразования трилистника и восьмерки вам поможет рис. 24.» [Pr95, §2] (Рис. 24] слева выполнен Д. Кроо.)

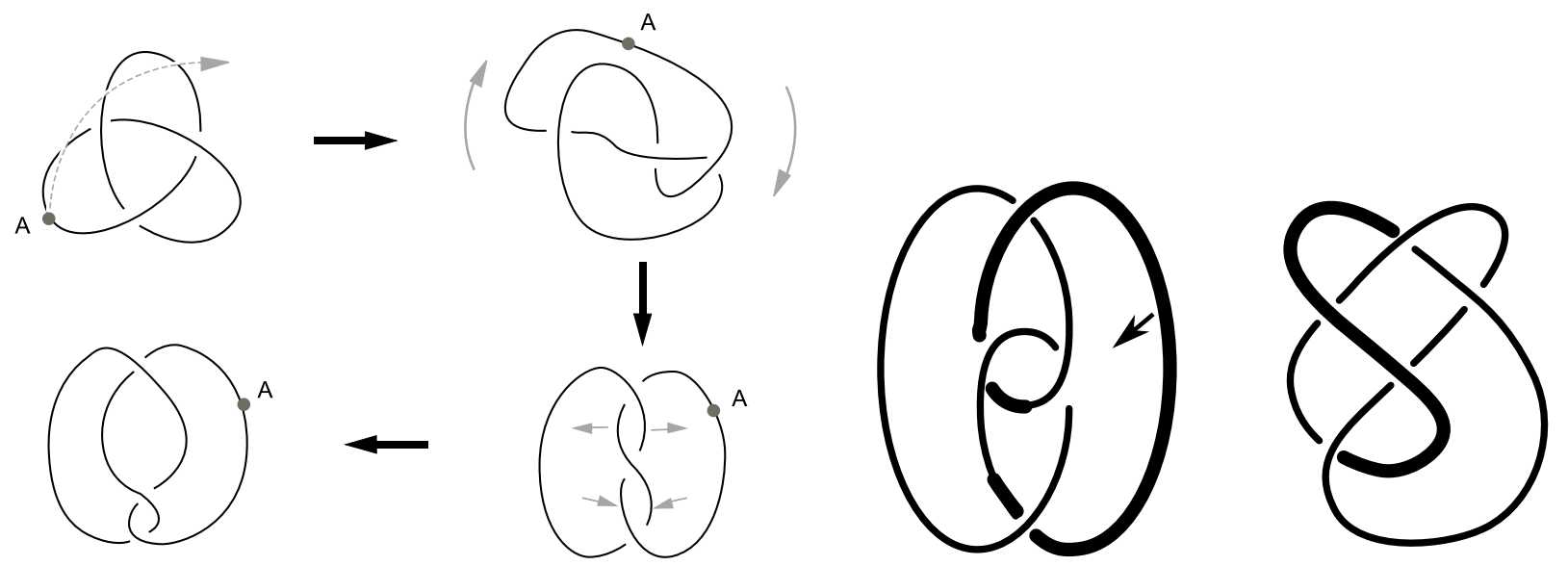

Рис. 24: Изотопии трилистника и восьмерки

(е) Рассмотрим два узла с совпадающими плоскими диаграммами в «горизонтальной» плоскости $\pi$. Для каждой точки $X$ в пространстве пусть $p(X)$ - прямая, проходящая через $X$ и перпендикулярная $\pi$. Пусть $h(X)$ - высота точки $X$ относительно $\pi$, положительная $(h(X)>0)$ если $X$ находится в верхнем полупространстве и отрицательная $(h(X)<0)$ если $X$ находится в нижнем полупространстве. Каждой точке $A$ первого узла поставим в соответствие точку $A$ второго узла с помощью следующей процедуры.

Случай 1: Проекиия точки А на $\pi$ не является перекрестком на плоской диаграмме. В этом случае прямая $p(A)$ пересекает первый узел только в точке $A$. Так как плоские диаграммы узлов совпадают, то прямая $p(A)$ пересекает второй узел также только в одной точке. Обозначим эту точку через $A^{\prime}$.

Случай 2: проекиия точки А на т является перекрестком на плоской диаграмме. В этом случае прямая $p(A)$ пересекает первый узел еще в одной точке $B$. Так как плоские диаграммы узлов совпадают, то прямая $p(A)$ пересекает второй узел тоже в двух точках: $C$ и $D$. Без ограничения общности можно считать что $h(C)>h(D)$. Тогда если $h(A)>h(B)$, то положим $A^{\prime}=C$, иначе $A^{\prime}=D$.

Для каждой точки $A$ первого узла и каждого числа $t \in[0,1]$ пусть $A(t)$ - точка на прямой $p(A)$ на высоте $h(A(t))=(1-t) h(A)+t h\left(A^{\prime}\right)$. По построению $A(0)=A, A(1)=A^{\prime}$, и искомой изотопией является преобразование первого узла, двигающее точку $A(0)$ к точке $A(1)$ с постоянной скоростью так, что в момент времени $t$ она находится в положении $A(t)$, является искомой изотопией.

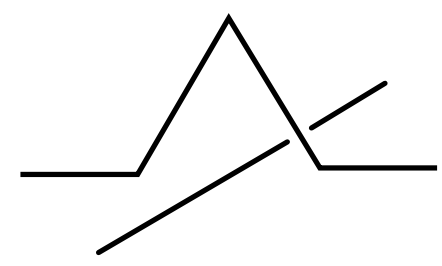

Рис. 25: Мостик через перекресток

1.3. См. рис. 25, Для каждого перекрестка на плоской диаграмме выберем на участке 
перекрестка, являющемся переходом, две точки, близкие к пересечению и находящиеся по разные стороны от него. Заменим отрезок между двумя выбранными точками «мостиком», соединяющим выбранные точки и «подымающимся» над плоской диаграммой. После замены всех перекрестков такими «мостиками» мы получим искомый узел.

1.4. (а) Используйте утверждения 5.1,b, 9.1, а и леммы 5.2,a,b, 9.2,a,b. Или можете воспользоваться утверждениями 6.1, a, b и леммой 6.2,

(b) Рассмотрим любую связную сумму $n$ трилистников. Согласно утверждениям 9.1, а и 9.3. а, инвариант Кэссона этого узла равен $n$. Следовательно, по лемме 9.2. a,b соответствующие узлы не изотопны для различных значений $n$.

2.2. (а) Чтобы отличить зацепление Хопфа от остальных, воспользуйтесь утверждением 4.1 и леммой 4.2. Чтобы отличить зацепление Уайтхеда от тривиального зацепления, воспользуйтесь утверждением 6.1 (или 10.3) и леммой 6.2 (или теоремой 10.2).

(b) Используйте утверждение 10.3 и теорему 10.2 ,

3.2. Выберем узел, проецирующийся на данную плоскую диаграмму тем же способом, что и в утверждении 1.3, Будем считать, что все «мостики» лежат в верхнем полупространстве относительно плоскости проекции. По предположению существуют точки $X$ и $Y$ узла, которые разбивают узел на две ломаные $p$ и $q$ такие, что

- $q$ лежит на плоскости проекции и проходит только через проходы;

- $p$ проецируется на ломаную $p^{\prime}$, которая проходит только через переходы.

Возьмем точку $Z$ в верхнем полупространстве и точку $T$ в нижнем полупространстве. Построим изотопию между заданным узлом и замкнутой ломаной $X Z Y T$, которая изотопна тривиальному узлу. Построение изотопии состоит из трех шагов, в каждом из которых точки $X, Y$ остаются фиксированными.

Шаг 1. Изотопия между $q$ u XTY. Предположим, что $q=A_{0} A_{1} \ldots A_{n}$, где $A_{0}=X$ и $A_{n}=Y$. Тогда изотопия получается последовательностью элементарных движений

$$
A_{0} A_{1} \rightarrow A_{0} T A_{1}, \quad T A_{1} A_{2} \rightarrow T A_{2}, \quad T A_{2} A_{3} \rightarrow T A_{3}, \quad \ldots T A_{n-1} A_{n} \rightarrow T A_{n}
$$

Шаг 2. Изотопия между р и $p^{\prime}$. Уберем все «мостики» с помощью элементарных движений.

Шаг 3. Изотопия между $p^{\prime}$ и $X Z Y$. Строится аналогично шагу 1.

3.3. Следует из утверждения 3.2 .

Другая идея доказательства (ср. [PS96, теорема 3.8]). Обозначим через $\pi$ горизонтальную плоскость, содержащую диаграмму. Для каждой точки $X$ в пространстве $p(X)$ и $h(X)$ определяются как в доказательстве утверждения 1.1.с. Пусть $l$ - прямая на плоскости, которая проходит через вершину $A_{0}$ плоской диаграммы, и пусть вся диаграмма лежит по одну сторону от прямой $l$. Пусть $A_{0}, A_{1}, \ldots, A_{n}$ - все вершины плоской диаграммы в порядке их появления при движении вдоль диаграммы в некотором направлении. Выберем точки $B_{0}, \ldots, B_{n}$ так, что $A_{i} \in p\left(B_{i}\right)$ для $i=1, \ldots, n$, и $h\left(B_{i}\right)<h\left(B_{j}\right)$ для $i<j$. Пусть $B_{n+1}-$ точка, проекция которой на $\pi$ близка к $A_{0}$, и $h\left(B_{n+1}\right)>h\left(B_{n}\right)$. Тогда узел $B_{0} \ldots B_{n} B_{n+1}$ изотопен тривиальному узлу. Действительно, по построению прямой $l$, проекция узла на любую плоскость, перпендикулярную $l$, является замкнутой несамопересекающейся ломаной. Остается только изменить перекрестки плоской диаграммы так, чтобы они согласовывались с проекцией построенного узла на плоскость $\pi$.

4.1. Oтвет: 1 для зацепления Хопфа и 0 для остальных зацеплений.

4.2. При движениях I и III число перекрестков, в которых первая компонента проходит над второй, не изменяется. При движении II это число изменяется на 0 или \pm 2 .

4.3. (а) Рассмотрим плоскую диаграмму зацепления. По лемме о четности (сформулированной перед утверждением 4.3) число таких перекрестков, где первая компонента проходит 
над второй, имеет ту же четность что и число перекрестков, где вторая компонента проходит над первой. Это в точности то, что нужно доказать.

(b) Примером является четвертое зацепление на рис. 4. Используя целочисленный коэффициент зацепления, можно доказать, что это зацепление не изотопно тривиальному, см. §8.

4.4. Существование. По лемме4.2 коэффициент зацепления по модулю 2 является изотопическим инвариантом. Справедливость скейн-соотношения легко проверить непосредственно.

Единственностъ. Предположим, что $\mathrm{f}$ - другой инвариант, отличный от $\mathrm{lk}_{2}$ и удовлетворяющий предположениям. Тогда $\mathrm{f}-\mathrm{lk}_{2}$ является изотопическим инвариантом, равном нулю на тривиальном зацеплении и инвариантным относительно изменений перекрестков. Согласно аналогу леммы 3.3 для зацеплений любая плоская диаграмма зацепления может быть получена из диаграммы зацепления, изотопного тривиальному, при помощи изменений перекрестков. Следовательно, $\mathrm{f}-\mathrm{lk}_{2}=0$.

5.1. (а) Если $P$ - такая точка на плоской диаграмме, как описано в утверждении 3.2 , то не существует $P$-скрещивающихся пар перекрестков. Следовательно, $P$-Арф-инвариант равен нулю.

5.2. (а) Пусть $P_{1}$ и $P_{2}$ - две отмеченные точки такие, что отрезок $P_{1} P_{2}$ содержит в точности один перекресток $X$.

Случай 1: $P_{1} P_{2}$ участвует в проходе. Тогда $X$ не образует ни $P_{1}$-скрещивающейся, ни $P_{2}$ скрещивающейся пары ни с каким другим перекрестком. Поэтому $P_{1}$ и $P_{2}$-Арф-инварианты диаграммы равны.

Случай 2: $P_{1} P_{2}$ участвует в переходе. Тогда $X$ делит диаграмму на две замкнутые ломаные $q_{1}$ и $q_{2}$ такие, что $P_{1}$ лежит на $q_{1}$, а $P_{2}$ лежит на $q_{2}$. Обозначим через $n_{1}$ (соответственно, $n_{2}$ ) число всех таких перекрестков на $q_{1}$ и $q_{2}$, в которых $q_{1}$ проходит над $q_{2}$ (соответственно, $q_{2}$ проходит над $\left.q_{1}\right)$. Обозначим через $N_{1}$ количество $P_{1}$-скрещивающихся пар, образованных $X$ и некоторым пересечением ломаных $q_{1}$ и $q_{2}$. Обозначим $P_{1}$-Арф-инвариант диаграммы $D$ через $\operatorname{arf}_{P_{1}} D$. Аналогичные обозначения будем использовать и для отмеченной точки $P_{2}$. Тогда

$$
\operatorname{arf}_{P_{1}} D-\operatorname{arf}_{P_{2}} D=N_{1}-N_{2}=n_{1}-n_{2} \overline{\overline{2}} n_{1}+n_{2} \underset{\overline{2}}{\equiv} 0
$$

где $D$ - данная плоская диаграмма. В последней формуле

- первое равенство выполнено поскольку пара перекрестков в $D$ является $P_{1}$-скрещивающейся или $P_{2}$-скрещивающейся (но не одновременно!) тогда и только тогда когда она образована перекрестком $X$ и некоторым пересечением ломаных $q_{1}$ и $q_{2}$;

- второе равенство выполнено поскольку $N_{1}=n_{1}$ и $N_{2}=n_{2}$; действительно, точка пересечения ломаных $q_{1}$ и $q_{2}$ образует $P_{1}$-скрещивающуюся (соответственно, $P_{2}$-скрещивающуюся) пару с $X$ тогда и только тогда когда в этой точке $q_{1}$ проходит над (соответственно, под) $q_{2}$;

• $\overline{\overline{2}}$ обозначает сравнение по модулю 2;

• последнее сравнение выполнено ввиду леммы о четности, примененной к ломаным $q_{1}$ и $q_{2}$.

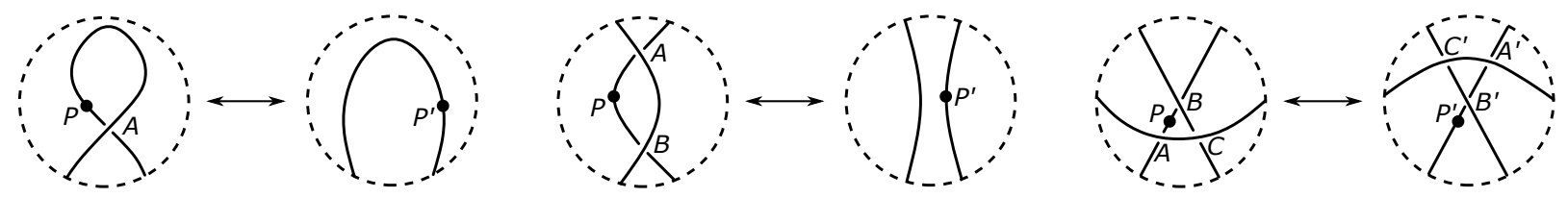

Рис. 26: Арф-инвариант не меняется при движениях Рейдемейстера

(b) Движение muna I. Выберем отмеченные точки до и после движения как показано 
на рис. 26 (слева). Проверьте, что перекресток $A$ не образует $P$-скрещивающуюся пару ни с одним другим перекрестком.

Движение muna II. Выберем отмеченные точки до и после движения, как показано на рис.26 (в центре). Проверьте, что ни один из перекрестков $A, B$ не образует $P$-скрещивающуюся пару ни с каким другим перекрестком.

Движение тuпа III. Выберем отмеченные точки до и после движения, как показано на рис. 26 (справа). Проверьте, что ни один из перекрестков $A, B$ не образует $P$-скрещивающуюся пару ни с каким другим перекрестком, и что ни один из перекрестков $A^{\prime}, B^{\prime}$ не образует $P^{\prime}$ скрещивающуюся пару ни с каким другим перекрестком. Затем проверьте, что произвольный перекресток $X$, отличный от $A, B, C$, образует $P$-скрещивающуюся пару с $C$, если и только если $X$ образует $P^{\prime}$-скрещивающуюся пару с $C^{\prime}$.

5.3. Рассмотрим любую связную сумму $K$ двух трилистников. Из утверждения 7.4.d следует, что $\operatorname{arf} K=0$. В то же время по результату задачи 5.1.b и утверждению 9.3, а $c_{2}(K) \neq 0$. Поэтому $K$ не изотопен тривиальному узлу.
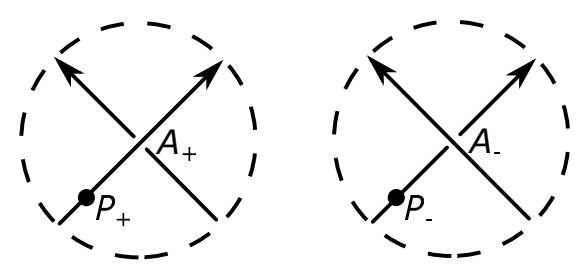

Рис. 27: К доказательству скейн-соотношения для Арф-инварианта

5.4. Существование. По лемме 5.2, Арф-инвариант является изотопическим инвариантом. Приведем указания к проверке скейн-соотношения. Выберем отмеченные точки $P_{+}, P_{-}$, как показано на рис. 27. Проверьте, что перекресток $A_{-}$не образует $P_{-}$-скрещивающуюся пару ни с каким другим перекрестком в $K_{-}$. Затем проверьте, что число таких перекрестков, которые образуют $P_{+}$-скрещивающуюся пару с $A_{+}$в $K_{+}$, сравнимо с $\mathrm{lk}_{2} K_{0}$ по модулю 2.

Единственность. Доказательство аналогично доказательству теоремы 4.4, Используйте саму лемму 3.3 вместо ее аналога для зацеплений.
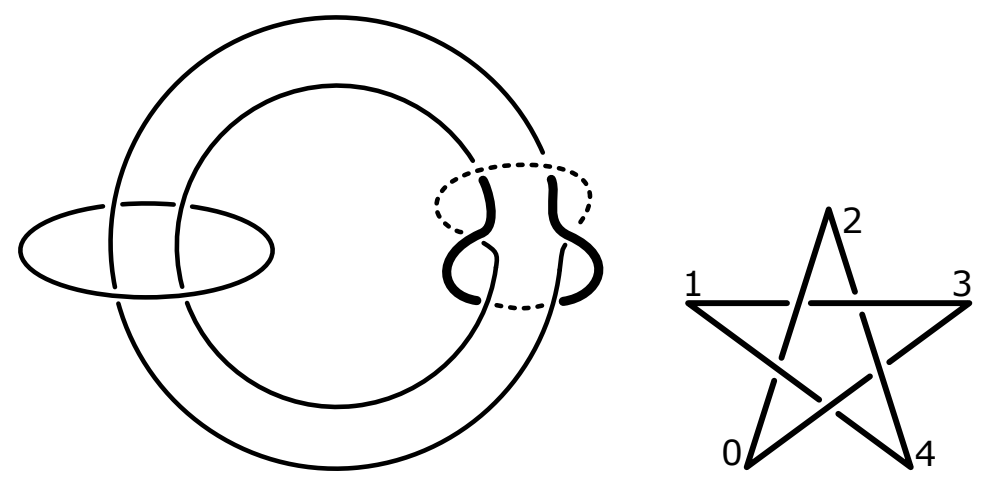

Рис. 28: Раскраска зацепления в 3 цвета и раскраска узла 5 в 5 цветов

6.1. Ответы: b,e,h - 3-раскрашиваемы, a,c,d,f,g,i - не раскрашиваемы. Пример раскрашенного в три цвета трилистника см. в [Pr95, стр. 30, рис. 4.3]. Правильную раскраску последней диаграммы с рис. 4 см. на рис. 28 слева. (Эта диаграмма была ошибочно названа нераскрашиваемой в три цвета в [Pr95, §4]. Эта небольшая ошибка была найдена Л. Баннором, С. Зотовой и Л. Кравцовой.)

6.3. (а) Большая часть п. (а) следует из леммы 6.2 и утверждений 6.1. d-h (см. Pr95, стр. 30]). Последняя диаграмма на рис. 4 отличается от тривиального зацепления числом 
правильных раскрасок плоской диаграммы. Докажите, что это число сохраняется при движениях Рейдемейстера.

(b) Плоская диаграмма называется раскрашиваемой в 5 иветов, если существует раскраска ее дуг в цвета $0,1,2,3,4$ такая, что хотя бы два цвета использованы, и в каждой точке пересечения если верхняя дуга имеет цвет $a$, а две нижние дуги - цвета $b$ и $c$, то $2 a \equiv b+c$ $(\bmod 5)$. Аналогично лемме 6.2 можно показать, что раскрашиваемость в 5 цветов сохраняется при движениях Рейдемейстера. Узел 51 является раскрашиваемым в 5 цветов (см. рис. 28 справа), а тривиальный узел - нет. Поэтому они не изотопны.

7.1. (b) Первое решение. Назовем ориентированную ломаную положительной, если ограниченная ею часть плоскости лежит слева от любого ее звена (здесь используется теорема Жордана, сформулированная в замечании 3.1). Покажите, что положительность ломаной сохраняется при элементарных движениях.

Указание ко второму решению. Положительность ломаной из предыдущего решения можно эквивалентно определить следующим образом. Будем говорить, что ориентированная ломаная $A_{1} \ldots A_{n}$ положительна, если для любой ее внутренней точки $O$ сумма ориентированных углов $\angle A_{1} O A_{2}+\angle A_{2} O A_{3}+\ldots+\angle A_{n-1} O A_{n}+\angle A_{n} O A_{1}$ положительна (т. е. индекс всякой внутренней точки ломаной относительно самой ломаной положителен).

7.2. Каждый из трех указанных ориентированных узлов переводится в ориентированный узел с противоположной ориентацией вращением на угол $\pi$ относительно «вертикальной» оси, проходящей через «самую верхнюю» точку узла (см. самую левую диаграмму на рис. 1 в первом и втором ряду для трилистника и восьмерки соответственно). Это вращение входит в непрерывное семейство вращений на угол $\pi t, t \in[0,1]$ относительно той же прямой. Это и есть требуемая изотопия.

7.7. (d) Проверьте, что всякая точка пересечения разных компонент в $K \# L$ получается из точки пересечения разных компонент в $K$ или точки пересечения разных компонент в $L$.

8.1. Ответы: $\pm 1 ; 0$.

8.3. (а) Доказательство аналогично доказательству утверждения 4.3, а. Рассмотрим плоскую диаграмму зацепления. Из леммы о тривиальности (сформулированной перед утверждением 8.3) следует, что сумма знаков точек пересечения, в которых первая компонента выше второй, противоположна сумме знаков точек пересечения, в которых вторая компонента выше первой. Поскольку перестановка компонент зацепления меняет знаки всех точек пересечения компонент, то коэффициент зацепления не меняется.

(b) Смена ориентации любой компоненты меняет знаки всех точек пересечения.

(c) Достаточно рассмотреть любую связную сумму пяти зацеплений Хопфа, у которых ориентации на компонентах выбраны таким образом, чтобы их коэффициент зацепления был равен -1 .

(d) Доказательство аналогично 7.4. d. Множество перекрестков в плоской диаграмме зацепления $K \# L$ является объединением множеств перекрестков в плоских диаграммах зацеплений $K$ и $L$, причем знак каждого перекрестка в $K \# L$ совпадает с знаком этого перекрестка в соответствующем ему зацеплении $K$ или $L$.

(е) Примером является зацепление Уайтхеда (оно не изотопно тривиальному по теореме 2.2, a).

9.1. (а) Oтветь: 0, 1 и -1 .

Тривиальный узел не имеет перекрестков, а значит в нем нет и скрещивающихся пар перекрестков. Поэтому инвариант Кэссона этого узла равен нулю.

Все три перекрестка трилистника имеют одинаковый знак. Так как трилистник имеет только одну скрещивающуюся пару перекрестков (вне зависимости от выбора отмеченной точки), то инвариант Кэссона этого узла равен 1. 
(b) Рассмотрим любую связную сумму пяти восьмерок. По п. (а) и утверждению 9.3, а ниже, инвариант Кэссона этого узла равен -5 .

9.2, 9.3. a, 9.4. доказательства аналогичны доказательствам леммы 5.2, утверждения 5.3 и теоремы 5.4 соответственно. Важно следить за знаками точек пересечения. Для доказательства леммы 9.2, а воспользуйтесь леммой о тривиальности, сформулированной перед утверждением 8.3.

9.3. (b) Рассмотрим любую связную сумму трилистника и восьмерки. По п. (а) и утверждению 9.17а инвариант Кэссона этого узла равен нулю. Однако по утверждениям 10.3. d,e и 10.5. с, многочлен Конвея этого узла равен $\left(1+t^{2}\right)\left(1-t^{2}\right) \neq 1$. Значит, этот узел не изотопен тривиальному узлу.

10.1. (b) Ответ: 0.

Замечание. Инвариант $\operatorname{arf}=c_{2} \bmod 2$ для зацеплений, вообще говоря, зависит от ориентации компонент (см. [CDM, 2.3.4] для инварианта $\left.c_{3} \bmod 2\right)$.

Пусть $D-$ плоская диаграмма некоторого зацепления. Обозначим через $\mathrm{cr} D$ количество перекрестков в $D$, а через $\operatorname{ch} D$ минимальное число изменений перекрестков, необходимое для получения из $D$ диаграммы зацепления, изотопного тривиальному (такая последовательность изменений перекрестков существует по аналогу леммы 3.3 для зацеплений).

10.2. Едиственность доказывается аналогично теоремам 8.4, 9.4, сначала решите задачу 10.3 .

Въвод сильной версии (для неупорядоченных защеплений) из слабой (для упорядоченных зацеплений). Достаточно доказать, что все инварианты $c_{n}$, определенные для упорядоченных зацеплений, сохраняются при изменении порядка компонент.

Пусть $D$ - плоская диаграмма некоторого зацепления с двумя или более компонентами и пусть $D^{\prime}$ - плоская диаграмма, полученная из $D$ изменением порядка компонент. Доказательство проведем индукцией по $\operatorname{cr} D$. Если $\operatorname{cr} D=0$, то $D$ - диаграмма зацепления, изотопного тривиальному, и по утверждению 10.3.b имеем $C(D)=0$ для любого порядка компонент. Предположим, что cr $D>0$; тогда продолжим доказательство индукцией по $\operatorname{ch} D$. Если $\operatorname{ch} D=0$, то $D$ - диаграмма зацепления, изотопного тривиальному; этот случай рассмотрен выше. Предположим, что $\operatorname{ch} D>0$. Пусть $D_{*}-$ зацепление, полученное из $D$ таким изменением перекрестка, что $\operatorname{ch} D_{*}<\operatorname{ch} D$. Обозначим через $D_{*}^{\prime}$ зацепление, полученное из $D^{\prime}$ изменением того же перекрестка. Тогда

$$
\pm\left(C(D)-C\left(D_{*}\right)\right)=C\left(D_{0}\right) \quad \text { and } \quad \pm\left(C\left(D^{\prime}\right)-C\left(D_{*}^{\prime}\right)\right)=C\left(D_{0}^{\prime}\right)
$$

где $D_{0}$ - диаграмма зацепления $K_{0}$ (с некоторым порядком компонент) на рис. 21, $D$ и $D_{*}$ - это $D_{+}$и $D_{-}$в некотором порядке, а $D_{0}^{\prime}$ обозначает то же самое для $D^{\prime}, D_{*}^{\prime}$. Заметим, что диаграммы $D_{*}$ и $D_{*}^{\prime}$ совпадают с точностью до порядка компонент. То же верно для диаграмм $D_{0}$ и $D_{0}^{\prime}$. Так как $\operatorname{ch} D_{*}<\operatorname{ch} D$ и $\operatorname{cr} D_{0}<\operatorname{cr} D$, то по предположению индукции имеем $C\left(D_{*}\right)=C\left(D_{*}^{\prime}\right)$ и $C\left(D_{0}\right)=C\left(D_{0}^{\prime}\right)$. Тогда $C(D)=C\left(D^{\prime}\right)$.

10.3. Oтветы: (a, b) 0; (c) $\pm t$; (d) $1+t^{2}$; (e) $1-t^{2}$; (f) $\pm t^{3}$; (g) $\pm t^{4}$; (h) $1+3 t^{2}+t^{4}$.

Замечание. Знаки в ответах к пп. (c), (f), (g) зависят от ориентации компонент.

Указание. Примеры вычислений для пп. (а), (c), и (d) см. в [CDM, 2.3.2].

10.4. Пусть $D-$ плоская диаграмма данного зацепления $K$.

(a) Для любой диаграмы $D_{*}$, полученной из $D$ изменением перекрестка, имеем $c_{0}(D)-$ $c_{0}\left(D_{*}\right)=0$, т. е. $c_{0}$ не меняется при изменениях перекрестков. По аналогу леммы 3.3 для зацеплений диаграмма $D$ может быть получена изменениями перекрестков из диаграммы зацепления, изотопного тривиальному. Утверждение следует из определения $c_{0}$ на тривиальном узле и утверждения 10.3, b. 
$(\mathrm{b}, \mathrm{c})$ Первые части обоих утверждений являются частными случаями п. (d). Вторые части обоих утверждений следуют из определения $c_{1}, c_{2}$ и теорем 8.4, 9.4.

(d) Доказательство индукцией по сr $D$. Если cr $D=0$, то $K$ изотопно тривиальному зацеплению. Если $K-$ узел, то $C(D)=1$. В противном случае, $C(D)=0$ по утверждению 10.3 ,b. Предположим, что $\operatorname{cr} D>0$; тогда продолжим доказательство индукцией по $\operatorname{ch} D$. Если $\operatorname{ch} D=0$, то $K$ изотопно тривиальному зацеплению; этот случай рассмотрен выше. Предположим, что $\operatorname{ch} D>0$. Пусть $D_{*}$ - зацепление, полученное из $D$ изменениями перекрестков и такое, что $\operatorname{ch} D_{*}<\operatorname{ch} D$. Тогда $\pm\left(c_{j}(D)-c_{j}\left(D_{*}\right)\right)=c_{j-1}\left(D_{0}\right)$, где $D_{0}-$ диаграмма с рис. 21, $D$ и $D_{*}$ - это $D_{+}, D_{-}$в некотором порядке. Заметим, что зацепление $D_{*}$ состоит из $k$ компонент, а зацепление $D_{0}$ состоит из $k^{\prime}=k \pm 1$ компонент. Поэтому если $j \leq k-2$, то $j-1 \leq k^{\prime}$, и если $j-k$ четно, то и $(j-1)-k^{\prime}$ четно. Так как $\operatorname{ch} D_{*}<\operatorname{ch} D$ и $\operatorname{cr} D_{0}<\operatorname{cr} D$, то по предположению индукции имеем $c_{j}\left(D_{*}\right)=c_{j-1}\left(D_{0}\right)=0$. Тогда $c_{j}(D)=0$.

(е) Докажите аналогично п. $(\mathrm{d})$ что $c_{j}(D)=0$ для любой плоской диаграммы $D$ u $j>\operatorname{cr} D$.

10.5. (а) Доказательство аналогично доказательству утверждения 10.4.d.

(c) Пусть $D$ и $E-$ плоские диаграммы зацеплений $K$ и $L$. Аналогично утверждению 10.4 , d покажите. что $C(D \# E)=C(D) C(E)$ индукцией по сr $D$ при фиксированном $E$.
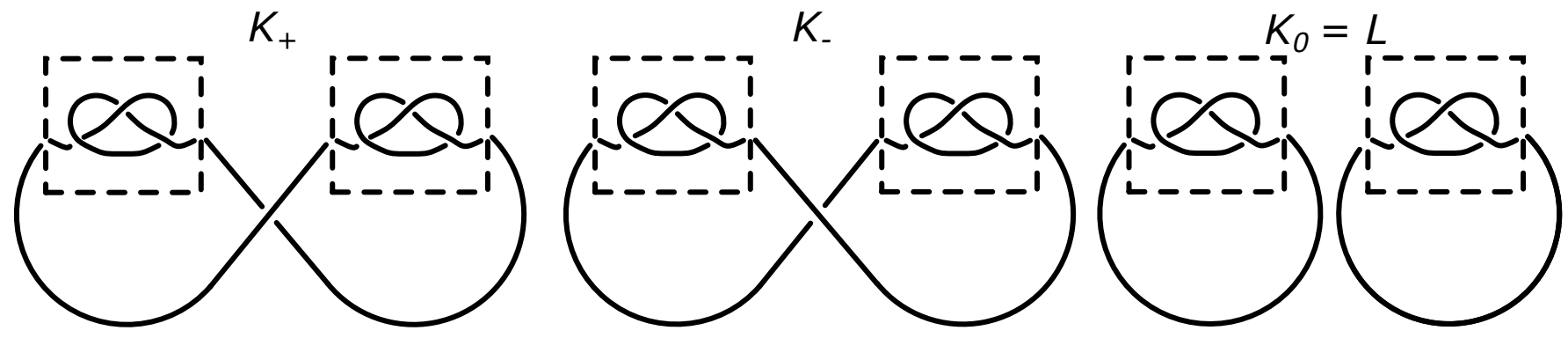

Рис. 29: Доказательство равенства $C$ (разделяемое зацепление $)=0$

10.6. (а) Следует из утверждений 10.3, c,f,g и пп. (b,c).

(с) Если $L-$ разделяемое зацепление, то существуют зацепления $K_{+}, K_{-}, K_{0}$ такие, что

- их плоские диаграммы отличаются как на рис. 21.

• зацепления $K_{+}$и $K_{-}$изотопны;

- зацепление $K_{0}$ изотопно $L$.

Получаем $C(L)=C\left(K_{0}\right)=\frac{1}{t}\left(C\left(K_{+}\right)-C\left(K_{-}\right)\right)=0$, см. рис. 29.

\section{Список литературы}

[A128] J. W. Alexander. Topological invariants of knots and links, Trans. Amer. Math. Soc., $30: 2$ (1928), 275-306.

[As] A. Asanau. A simple proof that connected sum of ordered oriented links is not welldefined, preprint.

[CDM] * S. Chmutov, S. Duzhin, J. Mostovoy. Introduction to Vassiliev knot invariants, Cambridge Univ. Press, 2012. http://www.pdmi.ras.ru/〜duzhin/papers/cdbook.

[CG83] J. H. Conway and C. M. A. Gordon, Knots and links in spatial graphs, J. Graph Theory 7 (1983), 445-453.

[CSK] * https://en.wikipedia.org/wiki/Connected_sum\#Connected_sum_of_knots 
[EEF] * Proposed by D. Eliseev, A. Enne, M. Fedorov, A. Glebov, N. Khoroshavkina, E. Morozov, A. Skopenkov, R. Živaljević. A user's guide to knot and link theory, https://www . turgor.ru/lktg/2019.

[Ga20] T. Garaev. An elementary proof of the existence of the Conway polynomial (in Russian), https://www.mccme.ru/circles/oim/mmks/works2019/garaev4.pdf ; an update is submitted to arxiv in November 2020.

[HC19] * C. Herbert Clemens. Two-Dimensional Geometries. A Problem-Solving Approach, AMS, 2019.

[Ka06] * L.H. Kauffman. Formal Knot Theory, Dover Publications, 2006.

[Ka06'] L.H. Kauffman. Remarks on Formal Knot Theory, arXiv:math/0605622 (note that the numbers and names of sections in table of contents in p. 1 are incorrect).

[Ka87] * L.H. Kauffman. On knots. Annals of Mathematics Studies. 115. Princeton University Press. 1987.

[Ko19] E. Kogan. Linking of three triangles in 3-space, arXiv:1908.03865.

[Ma18] * V. Manturov. Knot Theory. CRC press. 2018.

[Pr95] * В. В. Прасолов. Наглядная топология. М.: МЦНМО, 1995.

[Pr98] * J. H. Przytycki. 3-coloring and other elementary invariants of knots, Banach Center Publications, 42 Knot Theory, Warsaw, 1998, 275-295, arXiv:math.GT/0608172.

[PS96] * V. V. Prasolov, A. B. Sossinsky Knots, Links, Braids, and 3-manifolds. Amer. Math. Soc. Publ., Providence, R.I., 1996.

[Ra20] * A. Райгородский. Мат. Просвещение, 2020.

[Sk] * A. Скопенков. Алгебраическая топология с алгоритмической точки зрения, http://www.mccme.ru/circles/oim/algor.pdf.

[Sk14] * A. Skopenkov. Realizability of hypergraphs and Ramsey link theory, arxiv:1402.0658.

[Sk15] A. Skopenkov. Classification of knotted tori, Proc. A of the Royal Society of Edinburgh, 150:2 (2020), 549-567. Full version: arXiv:1502.04470.

[Sk16c] * A. Skopenkov, Embeddings in Euclidean space: an introduction to their classification, to appear in Boll. Man. Atl. http://www.map.mpimbonn.mpg.de/Embeddings_in_Euclidean_space:_an_introduction_to_their_classification

[Sk16i] * A. Skopenkov, Isotopy, submitted to Boll. Man. Atl. http://www.map.mpim-bonn.mpg.de/Isotopy.

[Sk18] * A. Skopenkov. Invariants of graph drawings in the plane. Arnold Math. J., 6 (2020) 21-55; full version: arXiv:1805.10237.

[Sk20] * A. Скопенков. Алгебраическая топология с геометрической точки зрения, Москва, МЦНМО, 2020 (2е издание). Эл. версия: http://www.mccme.ru/circles/oim/home/combtop13.htm\#photo 
[So89] * A. Sossinsky. Knots, links and their polynomials (in Russian). Kvant, 1989, N4, http://kvant.mccme.ru/1989/04/uzly_zacepleniya_i_ih_polinomy.htm.

[Su] * Д. Судзуки. Основы дзэн-буддизма. Наука дзэн - ум дзэн. Киев: Преса Украіни. 1992.

[ZSS] * Элементы математики в задачах: через олимпиады и кружки к профессии Сборник под редакцией А. Заславского, А. Скопенкова и М. Скопенкова. Изд-во МЦНМО, 2018. http://www.mccme.ru/circles/oim/materials/sturm.pdf.

В этом списке звездочками отмечены книги, обзоры и популярные статъи. 